\title{
BIOPHYSICAL OVERVIEW, SIGNIFICANT, SENSITIVE AND DISTURBANCE FEATURES OF THE \\ SADDLE HILLS, ALBERTA
}

\author{
Prepared for: \\ Resource Data Division \\ Alberta Environmental Protection \\ Edmonton, Alberta
}

Prepared by:

D.R. Bruhjell, A. Saxena and J.A. Bentz

Geowest Environmental Consultants Ltd.

Suite 203, Bedford Square

4209 - 99 Street

Edmonton, Alberta

T6E 5 V7

May, 1999 



\section{EXECUTIVE SUMMARY}

The Saddle Hills study area lies primarily within the Foothills Natural Region, with minor portions located within the Parkland Natural Region. The study area encompasses approximately $756 \mathrm{~km}^{2}$. The city of Grande Prairie and the town of Sexsmith are located approximately $26 \mathrm{~km}$ and $8 \mathrm{~km}$, respectively, south of the study area while the town of Spirit River is approximately $26 \mathrm{~km}$ to the north. Highway No. 2, running north - south, bisects the study area.

Increased resource development activity (petroleum exploration, agriculture, forestry, recreation etc.) in westcentral Alberta and the resulting surface disturbances have put pressure on sensitive areas within the Saddle Hills. Geowest Environmental Consultants Ltd. was contracted in 1995 by Alberta Environmental Protection to conduct a biophysical land classification and range inventory, and to identify and map significant, sensitive, and disturbance features, in support of resource management initiatives within the Saddle Hills area.

Specific objectives of the project were:

- To conduct a biophysical inventory at the ecosite hierarchical level within the Saddle Hills study area at a scale of 1:20000.

- To conduct an inventory of significant ecological features and sensitive features within the study area.

- To provide digitized ARC/INFO format biophysical maps and legends for the study area at a scale of $1: 20000$.

- To provide digitized ARC/INFO format thematic maps of significant ecological features, disturbance features and sensitive features at a scale of 1:20 000 .

- To collect range inventory data at each field site within the Saddle Hills study area.

- To provide a summary report according to specifications outlined in the Terms of Reference.

Thirteen different vegetation community types were identified, based on vegetative composition and landscape attributes which influence vegetation community development. The Aspen/prickly rose -low-bush cranberry/bluejoint community type is the most extensive in the area, with the Aspen/prickly rose-low-bush 
cranberry/wild sarsaparilla and Aspen-balsam poplar/green alder/bluejoint communities also comprising a significant portion of the area.

The study area possesses relatively unique physical and topographic features. The Saddle Hills represent what was once a piedmont plain. This plain has gradually been altered by a combination of processes (preglacial erosion and glaciation) creating conditions that differ from the surrounding topography. A steep escarpment forms the northern extremity of the Saddle Hills.

Oil and gas activity is the primary industrial land use of the area. However, lower elevations of the Saddle Hills study area are also subject to extensive disturbance resulting from agricultural activities, including cultivation, fence lines, trails, farm residences and cattle watering facilities. 


\section{ACKNOWLEDGEMENTS}

Geowest would like to acknowledge the contributions of the following people in bringing this project to completion.

Particular thanks are due to Ms. Marilyn Rayner and Mr. Keith Ainsley, Resource Data Division, Alberta Environmental Protection, for guidance throughout the project and provision of base map materials. In addition, we would like to thank Reg Schultz and Andre Legris for assistance with field work in 1995. Vegetation clipping for forage productivity determination was carried out in 1996 by Keith Ainsley, Beth Cornish, Andre Legris and Tim Toth, Alberta Environmental Protection. We also thank John Sisson for preparation of final maps and figures, Terry Lang for word processing and Della Clish of AcuDigital CAM for production of digital map products. 


\section{TABLE OF CONTENTS}

EXECUTIVE SUMMARY

ACKNOWLEDGEMENTS iii

LIST OF TABLES vi

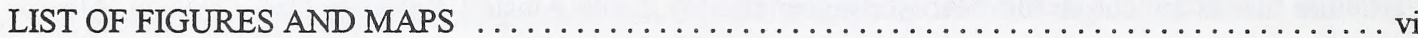

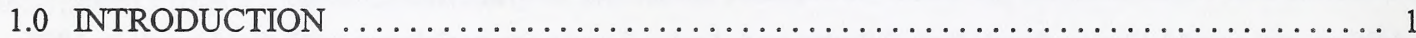

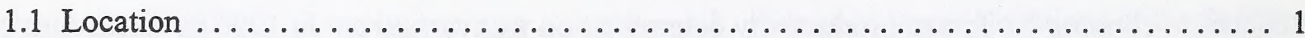

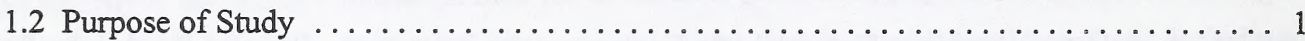

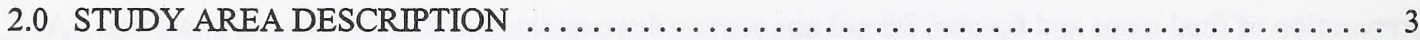

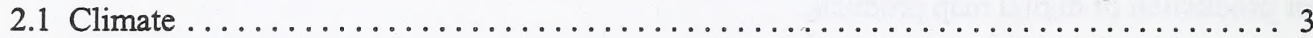

2.2 Physiography and Bedrock Geology ........................... 4

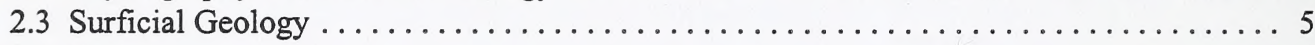

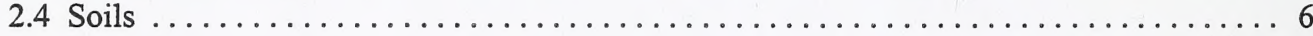

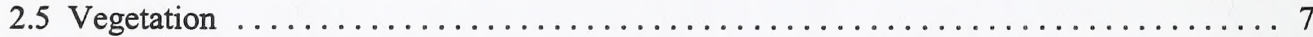

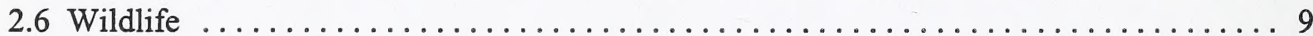

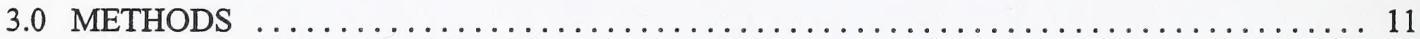

3.1 Ecological Land Classification Methods .......................... 11

3.2 Biomass Data Collection ................................... 12

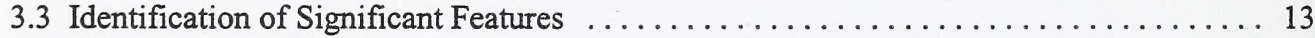

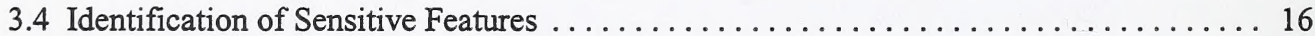

3.5 Identification of Disturbance Features . . . . . . . . . . . . . . . . . . 16

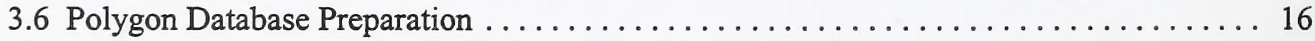

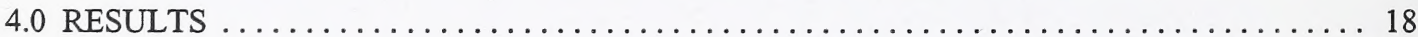

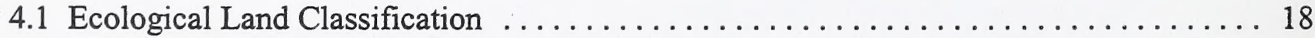

4.2 Description of Vegetation Community Types ........................ 18

4.3 Forage Productivity $\ldots \ldots \ldots \ldots \ldots \ldots \ldots \ldots \ldots \ldots \ldots \ldots \ldots \ldots \ldots \ldots \ldots \ldots \ldots \ldots \ldots \ldots \ldots, 26$

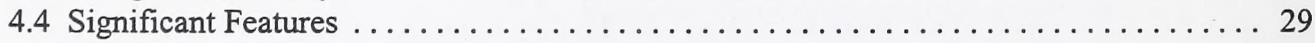

4.4.1 Significant Geological/Landform Features .................... 29

4.4.2 Significant Hydrological Features . . . . . . . . . . . . . . . . . 29

4.4.3 Significant Historic and Archaeological Features $\ldots \ldots \ldots \ldots \ldots \ldots \ldots \ldots$

4.4.4 Significant Palaeontological Features $\ldots \ldots \ldots \ldots \ldots \ldots \ldots \ldots \ldots \ldots \ldots$

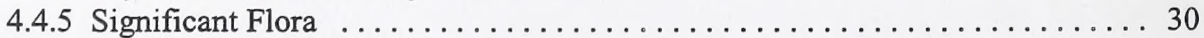

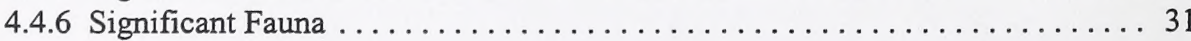


4.4.7 Significant Sites/Areas .............................. 38

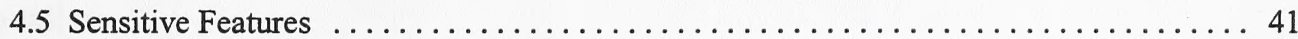

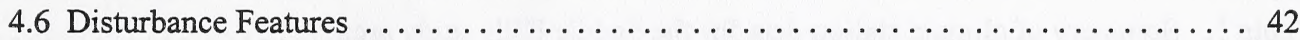

5.0 CHECKLISTS OF SIGNIFICANT FEATURES $\ldots \ldots \ldots \ldots \ldots \ldots \ldots \ldots \ldots \ldots \ldots \ldots \ldots \ldots$

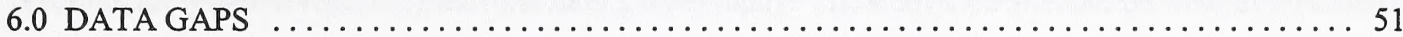

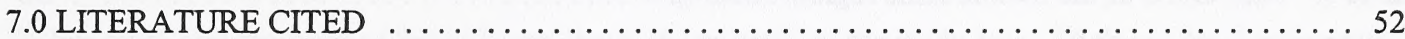

\section{LIST OF APPENDICES}

APPENDIX 1. Vegetation community type codes used in the polygon database. $\ldots \ldots \ldots \ldots$

APPENDDX 2. Latin names of plant species mentioned in this report. $\ldots \ldots \ldots \ldots \ldots$

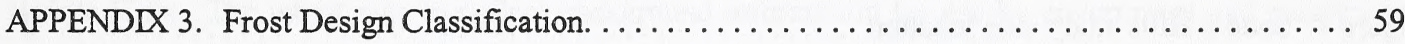

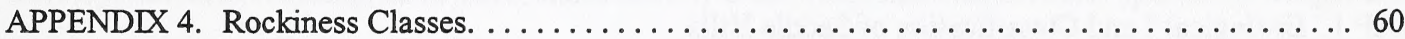

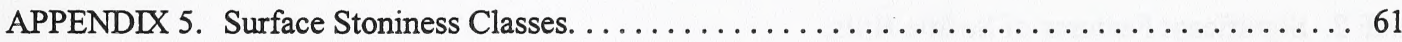

APPENDIX 6. Weights of vegetation clipped from range quadrats at survey sites

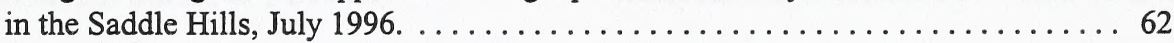

APPENDIX 7. Rare plant species which may occur in the Saddle Hills study area .......... 64

APPENDIX 8. Wildlife species in the Saddle Hills region, Alberta. . . . . . . . . . . . 66

APPENDIX 9. Photographs of representative features of the Saddle Hills study area. . . . . . . 72 


\section{LIST OF TABLES}

Table 1. Summary of climate station data for the Saddle Hills study area. . . . . . . . . . . . 4

Table 2. Average forage productivity of vegetation community types

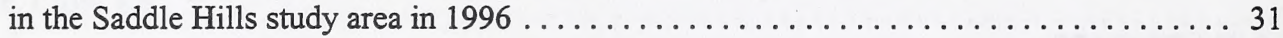

Table 3. Rare fauna of the Saddle Hills region, Alberta. . . . . . . . . . . . . . . 36

Table 4. Organisms Susceptible To Local Extinction Processes. . . . . . . . . . . . . . . 37

Table 5. Significant Fauna by Community Type. ..................... 41

\section{LIST OF FIGURES AND MAPS}

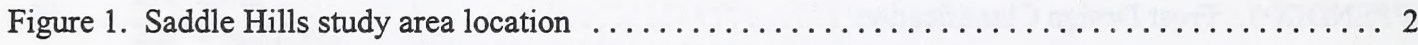

MAP 1. Ecological Land Classification of Saddle Hills.

MAP 2. Significant Features of Saddle Hills.

MAP 3. Sensitive Features of Saddle Hills.

MAP 4. Disturbance Features of Saddle Hills. 


\subsection{INTRODUCTION}

\subsection{Location}

The Saddle Hills study area is located in west-central Alberta, encompassing approximately $756 \mathrm{~km}^{2}$ of predominantly native vegetation and undulating topography. The study area includes portions of Townships 74-76, Ranges 3-8, west of the Sixth Meridian (Figure 1). The city of Grande Prairie is located approximately $26 \mathrm{~km}$ south and the town of Spirit River about $26 \mathrm{~km}$ north of the study area. Highway No.2 runs north south through the study area.

\subsection{Purpose of Study}

The purpose of this study, as commissioned by Alberta Environmental Protection, Edmonton, was to conduct a biophysical and range inventory, and identify significant, sensitive and disturbance features present in the Saddle Hills. The intent was to collect background information for use by government and industry in development of land management plans, and to identify areas where more detailed site-specific investigations may be necessary. The specific objectives were:

- To conduct a biophysical inventory at the ecosite hierarchical level within the Saddle Hills study area at a scale of 1:20 000;

- To conduct an inventory of significant ecological features and sensitive features within the study area;

- To collect range inventory data, as an aid in assessing the relative forage value of each plant community type;

- To provide digitized ARC/INFO format biophysical maps and legends for the study area;

- To provide digitized ARC/INFO format thematic maps of significant ecological, disturbance and sensitive features;

- To provide a summary report according to specifications outlined in the Terms of Reference. 
Digitized by the Internet Archive in 2017 with funding from University of Alberta Libraries 
FIGURE 1: SADOLE HILLS STUDY AREA

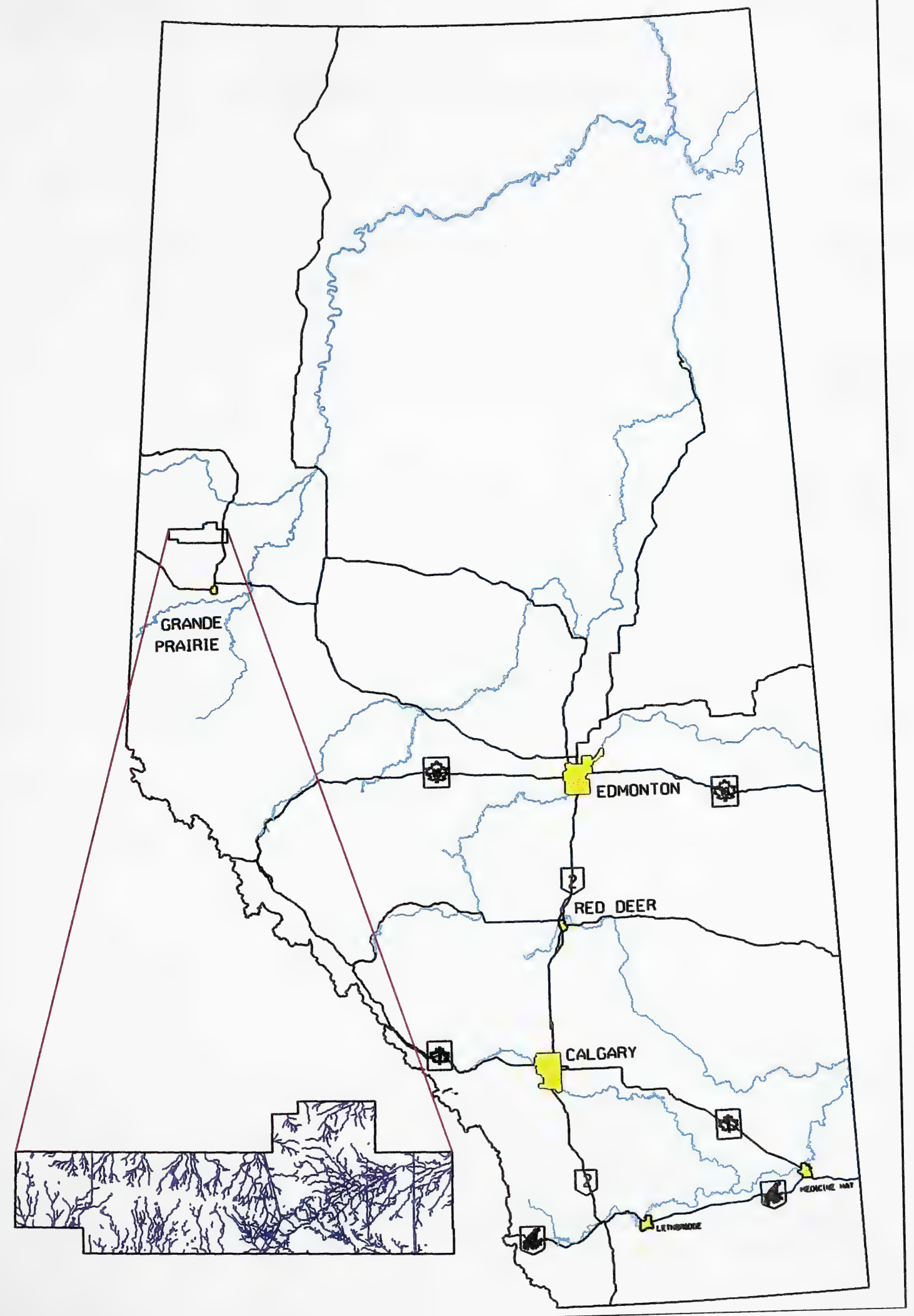





\subsection{STUDY AREA DESCRIPTION}

\subsection{Climate}

The study area occurs primarily in the Lower Foothills Subregion of the Foothills Natural Region, with minor portions within the Peace River Parkland Subregion of the Parkland Natural Region (Achuff 1994). The climate is predominantly continental, with moderately warm summer and cold winter temperatures. In comparison with adjacent lower elevation Boreal subregions, however, the climate in the Lower Foothills Subregion is somewhat cooler in summer and warmer in winter (Achuff 1994), due to the moderating influence of the mountains to the southwest.

The nearest climate station is at the Beaverlodge Research Station, approximately $24 \mathrm{~km}$ west of the study area (Environment Canada 1993; Table 1). The annual precipitation at Beaverlodge is $467.5 \mathrm{~mm}$, of which $66 \%$ (308.9 mm) falls as rain. By contrast, Edmonton and Grande Prairie have $465.8 \mathrm{~mm}$ and $450.2 \mathrm{~mm}$ of annual precipitation respectively. Of the mean annual precipitation at Beaverlodge, one half $(241.5 \mathrm{~mm})$ occurs during the growing season (May to August), with the greatest portion falling during June and July $(139.2 \mathrm{~mm})$. The average annual snowfall for this area is $187.2 \mathrm{~cm}$ with the greatest amount of snow falling from December to January (74.9 cm) (Environment Canada 1993).

Average annual temperature at Beaverlodge is $2.0^{\circ} \mathrm{C}$. Edmonton and Grande Prairie, by contrast, have average annual temperatures of $2.1^{\circ} \mathrm{C}$ and $1.6^{\circ} \mathrm{C}$ respectively. July and August are the hottest months at Beaverlodge, with a mean temperature of $15^{\circ} \mathrm{C}$ between the two months and an average daily maximum temperature of $21.3^{\circ} \mathrm{C}$. December and January are the coldest months with an average temperature of $-12.7^{\circ} \mathrm{C}$ and an average daily minimum temperature of $-17.3^{\circ} \mathrm{C}$. Recorded extreme temperatures range from a maximum of $36.7^{\circ} \mathrm{C}$ to a minimum of $-47.8^{\circ} \mathrm{C}$. 
Table 1. Summary of climate station data for the Saddle Hills study area. ${ }^{1}$

\begin{tabular}{|c|c|c|c|c|c|c|c|c|}
\hline Station & Lat. N & Long. W & $\begin{array}{l}\text { Elev. } \\
(\mathrm{m})\end{array}$ & $\begin{array}{l}\text { Anuual } \\
\text { Precip. } \\
\text { (mm) }\end{array}$ & $\begin{array}{l}\text { Precip. } \\
\text { May-Aug. } \\
(\mathrm{mm})\end{array}$ & $\begin{array}{l}\text { Degree Days } \\
\text { Above } 5^{\circ} \mathrm{C} \\
\text { (May-Aug) }\end{array}$ & $\begin{array}{l}\text { Mean } \\
\text { Daily } \\
\text { Temp. } \\
\text { May-Aug. } \\
\left({ }^{\circ} \mathrm{C}\right) \\
\end{array}$ & $\begin{array}{l}\text { Mean Daily } \\
\text { Temp. } \\
\text { June-July } \\
\left({ }^{\circ} \mathrm{C}\right)\end{array}$ \\
\hline Beaverlodge CDA & $55^{\circ \prime} 12$ & $\begin{array}{l}119^{\circ} \\
24^{\prime}\end{array}$ & 745 & 467.5 & 241.5 & 1007.7 & 13.1 & 14.3 \\
\hline $\begin{array}{l}\text { White Mountain } \\
\text { LO }\end{array}$ & $55^{\circ} 42^{\prime}$ & $\begin{array}{l}119^{\circ} \\
14^{\prime}\end{array}$ & 1093 & - & 294.1 & - & 12.0 & 13.1 \\
\hline Fairview ${ }^{2}$ & $56^{\circ} 04^{\prime}$ & $\begin{array}{l}118^{\circ} \\
23^{\prime}\end{array}$ & 670 & 453.7 & 245.2 & 1105.7 & 13.9 & 15.3 \\
\hline Grande Prairie $A^{2}$ & $55^{\circ} 11^{\prime}$ & $\begin{array}{l}118^{\circ} \\
53^{\prime}\end{array}$ & 666 & 450.2 & 239.2 & 1084.7 & 13.8 & 15.1 \\
\hline Edmonton Int'l $\mathrm{A}^{2}$ & $53^{\circ} 18^{\prime}$ & $\begin{array}{l}113^{\circ} \\
35^{\prime}\end{array}$ & 715 & 465.8 & 289.4 & 1096.0 & 13.9 & 15.1 \\
\hline
\end{tabular}

' Canadian Climate Normals 1961 - 1990, Atmospheric Environment Service; Environment Canada 1993

${ }^{2}$ Included for comparison purposes

Prevailing winds are from the west to northwest, with available data suggesting an average wind speed of approximately $12 \mathrm{~km} / \mathrm{h}$. Total growing degree days for the area is 1244, with 1007.7 occurring from May to August. By contrast, Edmonton has 1567 total growing degree days while Grande Prairie has 1324 (Environment Canada 1993).

Long term observations from the first four climate stations listed in Table 1 indicate a fairly uniform regional climate. However, considerable variation can occur in yearly rainfall patterns. Local topography can also modify the local climate because of changes in elevation, slope and/or aspect. For example, the comparatively greater precipitation recorded at nearby White Mountain Lookout, to the northwest of the study area, is typical of hilly elevated areas in the region.

\subsection{Physiography and Bedrock Geology}

Topographic conditions of the Saddle Hills can be described as gently to moderately sloping, undulating and 
locally hummocky. Elevations vary from a topographic high of approximately 991 masl (metres above sea level) to a topographic low of 564 masl in the Bad Heart River valley.

The Saddle Hills are the remnants of a former piedmont plain. This plain, consisting primarily of sandstone, was gradually eroded during pre-glacial times and later smoothed by glaciation.

Because of overlying glacial deposits of more recent origin, bedrock lies at or close to the surface only at scattered localities. The study area is underlain by a series of marine and non-marine sandstones, siltstones, and shales of Upper Cretaceous age. Dipping slightly towards the south, they become exposed along the steep escarpment that forms the northern extremity of the Saddle Hills. Two main formations occur, as described by Van Waas (1972). The Wapiti Formation, consisting of sandstone, siltstone, shale and coal, is the uppermost formation, covering the southern portion of the area. It is underlain by the Puskwaskau Formation, consisting of dark grey shales. This formation often results in the failures seen along the north escarpment. The Bad Heart Formation, consisting of shales, silty shale and iron-bearing sandstone, is limited to a narrow zone north of the Saddle Hills (TERA Environmental Consultants Ltd. 1993).

\subsection{Surficial Geology}

Surficial deposits of the study area are of both glacial and post-glacial origin (Odynsky et al. 1961). These deposits include till, glaciolacustrine, glaciofluvial, and more recent fluvial, colluvial, and organic deposits.

Laurentide ice sheets covered most of the area during the Pleistocene epoch. Glacial drift from this glaciation forms ablation and hummocky morainal veneer and blanket landforms. These till deposits tend to occur in topographically higher elevations of the Saddle Hills. Glaciolacustrine deposits, typically fine textured and non-stony, form remnant beach landforms. These are often found in lower areas, either as veneers or blankets over till (TERA Environmental Consultants Ltd. 1993).

Some surficial deposits show characteristics of more than one ice advance. An example of this occurs in the Braeburn area, close to the centre of the study area, where the parent material appears to be underlain by a much older till (Odynsky and Newton 1959). Three distinct glacial deposits can be found in this area. The first consists of a grayish-brown to brown sandy clay till that is somewhat stony, has numerous coal flecks 
and is generally considered to be derived from the Wapiti Formation (Odynsky and Newton 1959). Glaciofluvial deposits, consisting of boulders, sands or gravels, are typically associated with this till deposit. The second deposit consists of a well-sorted, stratified till. This deposit, derived from the Smoky River shales (north of the study area), is a dark greyish-brown clay with few stones and numerous gypsum crystals (Odynsky et al. 1961). Van Waas (1972) described the third deposit as a shallow till over sandstone. This deposit is a yellowish brown, sandy, stony till with fragments of sandstone.

Both glaciofluvial and fluvial deposits occur adjacent to stream courses. Glaciofluvial deposits dominate the higher terraces, whereas more recent fluvial deposits are found on the lower terraces and floodplains. Peat and organic silt and clay infill poorly drained terrain depressions and recent lake basins forming organic bogs and fens. Colluvial slopewash, consisting of gravity-transported silt, sand and clay, with till inclusions, forms veneers and blankets on slopes in the area (TERA Environmental Consultants Ltd. 1993).

Odynsky and Newton (1959) noted a gravelly deposit in Section 7, Township 75, Range 5, W6M, different from other glacial deposits in this area. They conclude that it most resembles the Tertiary deposits capping the Cypress Hills in southeastern Alberta.

\subsection{Soils}

Soils belonging to the Luvisolic Order dominate the area. These soils generally have light-coloured, eluvial A horizons and illuvial B horizons in which silicate clay has accumulated. A Luvisolic B horizon must have the specified increase in clay over that in the eluvial horizon, clay skins indicative of translocated clay accounting for $1 \%$ or more of the area of a section through the horizon, and be at least $5 \mathrm{~cm}$ thick. Only soils from the Gray Luvisol Great Group were found within the study area. These soils usually have welldeveloped, platy Ae horizons of low chroma, Bt horizons with moderate to strong blocky structures, calcareous $\mathrm{C}$ horizons, and a sola of high base saturation. Gray Luvisols generally occur under mixed forest vegetation.

Soils belonging to the Brunisolic Order were also found in the study area. These soils have sufficient development to exclude them from the Regosolic Order, but they lack the degree of horizon development specified for soils of other orders. Brunisols under forest conditions generally have a brownish-coloured Bm 
horizon at least $5 \mathrm{~cm}$ thick. Both the Eutric and Dystric Great Groups of the Brunisolic Order are found in the Saddle Hills. These Great Groups are separated on the basis of $\mathrm{pH}$ of the uppermost $25 \mathrm{~cm}$ of soil. Dystric Brunisols have a pH less than 5.5 in the uppermost $25 \mathrm{~cm}$ while Eutric Brunisols have a pH of 5.5 or greater in the uppermost $25 \mathrm{~cm}$. The distribution of Eutric and Dystric Great Groups refiects the $\mathrm{pH}$ of the surficial materials which is in turn influenced by the underlying bedrock geology.

Soils of the Gleysolic Order were not commonly sampled in the Saddle Hills. These soils have features indicative of periodic or prolonged saturation by water, and the sites are typified by reducing conditions. Gleysols often occur in shallow depressions and on wet lowlands. They are usually associated with either a high groundwater table at some period of the year or temporary saturation above a relatively impermeable layer. Vegetation often differs from the surrounding soils due to the moisture content and poor internal drainage. Gleysols have either matrix colours of low chroma or distinct to prominent mottles of high chroma in the upper $50 \mathrm{~cm}$. This suggests localized oxidation of ferrous iron and deposition of hydrated ferric oxides. Although these soils were not commonly sampled in the study area, it is probable that they dominate poorly drained sites.

Soils belonging to the Regosolic Order occur along stream valleys and on steeper slopes. These soils are "young" and lack well-developed profiles. This poor profile development may be due to a number of factors, including the youthfulness of the parent material (for example, recent alluvium), instability of the material (such as colluvium on slopes subject to mass wasting), the nature of the material (for example, dominated by quartz sand) and climate (cold environments).

Soils belonging to the Organic Order are infrequent in the study area. Organic soils are generally saturated with water for long periods and are derived from the vegetation that grows in these very poorly drained areas. Soils in this order must contain at least $30 \%$ organic matter by weight and are further differentiated based on the level of decomposition of the organic material. Only Mesisols, organic soils with partially decomposed organic materials, were described in the study area.

\subsection{Vegetation}

Most of the Saddle Hills study area occurs within the Lower Foothills Natural Subregion. Small portions 
near the north and south boundaries are classed within the Peace River Parkland Natural Subregion (Achuff 1994). Over most of the study area, mixedwood forests that are typical of the Lower Foothills Natural Subregion predominate. These mixedwood forests consist of white spruce (Picea glauca), black spruce (Picea mariana), lodgepole pine (Pinus contorta), aspen (Populus tremuloides), balsam poplar (Populus balsamifera), and white birch (Betula papyrifera). The understory low shrub vegetation is variable although species such as prickly rose (Rosa acicularis), low-bush cranberry (Viburnum edule), willows (Salix spp.), and saskatoon (Amelanchier alnifolia) are common components. Common species in the forb and graminoid layers include wild sarsaparilla (Aralia nudicaulis), cream-colored peavine (Lathyrus ochroleucus) and bluejoint (Calamagrostis canadensis).

Portions of the Saddle Hills study area, primarily near the northeastern and southeastern boundaries, are included within the Peace River Parkland Natural Subregion. The upland forests of the Peace River Parkland Subregion are dominated by aspen and white spruce with no lodgepole pine, and lesser amounts of balsam poplar on wetter sites. Understory vegetation is typically dominated by green alder (Alnus crispa), prickly rose, low-bush cranberry, red-osier dogwood (Cornus stolonifera), bunchberry and wild sarsaparilla (Aralia nudicaulis). Grasslands occurring on steep, south facing valley slopes are dominated by wheat grass (Agropyron spp.)- sedge (Carex spp.) communities. These grasslands are noted for supporting disjunct species, often those with a more southerly or westerly distribution (Achuff 1994).

Imperfectly drained sites are typically dominated by a mixture of aspen and balsam poplar, while poorly drained sites with good aeration develop balsam poplar stands. Other poorly drained sites commonly exhibit a black spruce - tamarack (Larix laricina) overstory with an understory of common Labrador tea (Ledum groenlandicum), bog cranberry (Vaccinium vitis-idaea), and mosses. Tree growth on these sites is slow because of poor nutrient status, high water table and lack of aeration, and low soil temperature (Strong 1992).

The actual community and species representation at any given site will be influenced by numerous factors including slope and aspect, moisture regime, soil properties, and disturbance type and intensity. Detailed discussion of the vegetation of the study area is presented in Section 4.2. 


\subsection{Wildlife}

Because of the heterogeneous nature of the vegetation communities within the Saddle Hills, a broad complement of wildlife species is supported. Based on provincial ranges described for mammals (Smith 1993), birds (Semenchuk 1992), herpetiles (Russell and Bauer 1993), and fish (Nelson and Paetz 1992), the Saddle Hills study area is anticipated to include an assemblage of at least 47 mammal species, 73 bird species, 3 amphibian species, and 15 fish species.

The list of faunal species anticipated to occur in the Saddle Hills includes several significant species which are considered to be at risk in Canada or within the province. One mammal species, the wolverine (Gulo gulo), has been designated by the Committee on the Status of Endangered Wildlife in Canada (COSEWIC) as nationally 'vulnerable' (a species of special concern because of characteristics that make it particularly sensitive to human activities or natural events; COSEWIC 1998). On a provincial scale, 3 mammal species and one bird species are blue-listed, and 4 mammal and 8 bird species are yellow-listed (Alberta Environmental Protection 1996). A detailed discussion of the significant fauna that occur in the Saddle Hills study area is presented below in Section 4.4 .

Some species are at the limits of their Alberta range in the Saddle Hills or have isolated or disjunct populations in the study area. Examples of such species in the Saddle Hills include the arctic shrew (Sorex arcticus), usually found at low elevations in the province, and the long-legged bat (Myotis volans), which generally occurs in the mountains and foothills but may range into higher elevation portions of the Saddle Hills.

Also of primary significance in the study area are several large game species and furbearing animals of extreme economical, ecological, and aesthetic value. Approximately 800 - 1,000 elk, or wapiti, (Cervus canadensis) are estimated to winter in the Saddle Hills / Spirit Ridge area (D. Hervieux, Alberta Environ. Prot., Grande Prairie, personal communication). Moose (Alces alces) are also abundant in the Saddle Hills, with mule deer (Odocoileus hemionus), white-tailed deer (Odocoileus virginianus), gray wolf(Canis lupus), and black bear (Ursus americanus) all present as well. Trapping records from Alberta Environmental Protection also confirm the presence of pine marten (Martes americana), fisher (Martes pennanti), mink (Mustela vison), and lynx (Lynx canadensis) in the study area (Alberta Fish and Wildlife Division, 1996 
unpubl. data).

Mammal use of forested habitats in the Saddle Hills area is closely related to stand age and, thus, stand structure. Species that require dead trees (snags) for nesting and/or foraging (for example, woodpeckers, pine marten, and red squirrel) or which nest or feed in the canopy, are commonly found in old stands where canopy height and snag density are highest. On the other hand, species that forage on shrubs or saplings (such as snowshoe hare and moose) are generally more common in young stands where the density of shrubs and saplings is highest.

A diverse assemblage of breeding bird communities is found in the Saddle Hills, due to the heterogenous nature of the boreal mixedwood forests. Forest-interior species such as pileated woodpecker (Dryocopus pileatus) and ovenbird (Seiurus aurocapillus) occupy tracts of mature and old growth deciduous and mixedwood forests. Edge-adapted birds such as warbling vireo (Vireo gilvus) and common yellowthroat (Geothlypis trichas) inhabit natural forest openings such as wetland margins.

On a regional basis, the Saddle Hills area is rated as Class 7, the lowest category, by the Canada Land Inventory (CLI) for waterfowl production capability (CLI 1971). Some production of waterfowl, including both diving and dabbling ducks occurs on larger lakes such as Hilltop Lake. Numerous wetlands provide seasonal habitats for migrating waterfowl. Green-winged teal (Anas crecca), blue-winged teal (Anas discors), northern pintail (Anas acuta), and Canada goose (Branta canadensis) are some of the more common species in the area.

Warm-water fish species capable of surviving in shallow turbid waters likely predominate the fish assemblage of the Saddle Hills. Based on species ranges described by Nelson and Paetz (1992), these likely include chubs (Platygobio gracilis and Couesius plumbeus), shiners (Richardsonius balteatus and Notropis hudsonius), and suckers (Catostomus spp.). Brook stickleback (Culaea inconstans) may be the most common fish species, due to its affinities to small, shallow bogs and beaver ponds. This species has a high tolerance to conditions of low oxygen and often occurs in areas where other fish could not survive. 


\subsection{METHODS}

\subsection{Ecological Land Classification Methods}

Ecological Land Classification (ELC) is a hierarchical landscape mapping system in which the land surface is subdivided and classified into areas of similar environments. The map units are characterized by recurring patterns of surficial materials, landform, soil and vegetation.

The primary method used to derive ecological units is aerial photo interpretation. The land surface is divided into units according to factors such as slope, landform, drainage, parent materials and vegetation. After background data compilation and the initial interpretation, field checks are carried out to verify descriptions of the map units and to compile more detailed site, soil and vegetation information.

Field sampling for detailed site and vegetation description was conducted from August 22 to August 30, 1995, according to methods outlined in the Ecological Land Survey Site Description Manual (Alberta Environmental Protection 1994). Initially, potential field sample sites were selected by using aerial photographs. Site locations were chosen to document the range of environmental conditions throughout the area. At each site, information was collected on soils, parent materials, vegetation composition and site characteristics, using standard field plot forms. Wildlife observations were also recorded. In total, 100 detailed plots were established.

Plant taxonomy follows Moss (1983) with common names conforming to the Alberta Vegetation Species List (Alberta Environmental Protection 1993). Latin and common names of all plant species mentioned in this report are given in Appendix 2. Photographs were also taken at each site to illustrate physiographic and physiognomic characteristics.

To classify and map ELC units, the landscape is generally divided into a four tiered hierarchical system based on dominant landscape characteristics - Natural Region and Subregion, Ecodistrict, Ecosection and Ecosite. The basic unit used for mapping in this study was the ecosite level at a mapping scale of 1:20,000. Final cartography was also completed at a scale of 1:20,000. The higher levels of classification were considered 
in the initial interpretation but omitted from the final mapping.

Each ecosite unit was given a descriptive map unit symbol or code. For example, for the ecosite symbol GL1, GL describes the primary landform or parent material, in this case glaciolacustrine, while the following numeric character, 1 , describes a subdivision based on soil, vegetation or physiographic features. Further description of the mapping codes used is given in Section 4.1 and on the Map 1 legend.

Map units (ecosites) are described in detail in the legend accompanying the Ecological Land Classification map. Ecosites are arranged alphabetically in the legend according to the surficial material code that forms the first part of the map symbol. Biophysical features included in the legend are as follows: landform and surficial materials, vegetation, soil classification, slope (\%), soil drainage, surface soil texture, subsurface soil texture, soil permeability, depth $(\mathrm{cm})$ to bedrock, other impermeable layers or water table, surface rockiness class, surface stoniness class, shrink-swell potential, potential frost action and flood hazard.

Vegetation community types in the study area were identified using aerial photograph interpretation and field data collection. Some community types identified were not intensively sampled in the field.

\subsection{Biomass Data Collection}

To assess relative forage value of vegetation community types, biomass data were collected, from July 23 to 29, 1996. Guidelines outlined in the Ecological Land Survey Site Description Manual (Alberta Environmental Protection 1994), were generally followed, with the exception of microplot size. At each of the 100 survey sites documented in 1995 , one circular microplot $1 \mathrm{~m}$ in diameter $\left(0.785 \mathrm{~m}^{2}\right)$ was established in an area representative of the community type. All live graminoids, forbs and low-growing shrubs within the microplot were clipped to ground level, in order to determine annual forage productivity. The clipping was carried out in mid-summer, as close as possible to the time when vegetation had reached its peak production. Graminoids, forbs and low-growing shrubs were each bagged separately. The bags were airdried and weighed. The data from all sites were then grouped according to vegetation community type, and average annual production within each community type calculated in $\mathrm{kg} / \mathrm{ha}$ for each layer. 


\subsection{Identification of Significant Features}

The identification and mapping of significant features, particularly of rare flora and fauna, relied heavily on review of existing information and on extrapolation from studies in adjacent areas. Detailed field study will be required in many cases to confirm the occurrence of significant flora and fauna specifically within the study area.

Environmentally significant areas (ESAs) are areas deemed to be important for maintaining ecological processes, and are also often sensitive to disturbance. The significance of sites within the Saddle Hills study area was based on a consideration of 14 criteria adapted from Eagles (1984), including:

- areas which perform a vital environmental, ecological or hydrological function such as aquifer recharge

- areas which contain rare or unique geological or physiographic features

- $\quad$ areas which contain significant, rare or endangered plant or animal species

- $\quad$ areas which are unique habitats with limited representation in the region or are a small remnant of once large habitats which have virtually disappeared

- areas which contain an unusual diversity of plant and/or animal communities due to a variety of geomorphological features and microclimatic effects

- areas which contain large and relatively undisturbed habitats and provide sheltered habitat or species which are intolerant of human disturbance

- areas which provide an important linking function and permit the movement of wildlife over considerable distances, including migration corridors and migratory stopover points

- areas which contain plants, animals or landforms which are unusual or are of local, regional, provincial, national or international significance

- areas that are excellent representatives of one or more ecosystems, habitats or landscapes

- $\quad$ areas with intrinsic appeal due to widespread community interest or the presence of highly valued features or wildlife species valued for hunting

- $\quad$ areas with lengthy histories of scientific research 
- areas containing specific old-growth values or older forest stands

- $\quad$ areas which perform a vital function for wildlife in the area

- $\quad$ areas with cultural, historical or archaeological significance.

The significance of each site was categorized according to Eagles (1984) as follows:

\begin{tabular}{|c|c|c|}
\hline International & - & features which are unique in the world \\
\hline National & - & $\begin{array}{l}\text { features which are limited in distribution at a national level or which are the } \\
\text { best or only representatives in Canada }\end{array}$ \\
\hline Provincial & - & $\begin{array}{l}\text { features which are of limited distribution or are the best examples of a } \\
\text { feature in the province }\end{array}$ \\
\hline Regional & - & $\begin{array}{l}\text { features which are of limited distribution or are the best examples of a } \\
\text { feature in the region }\end{array}$ \\
\hline Local & - & $\begin{array}{l}\text { features which are of limited distribution or are the best examples of a } \\
\text { feature in the study area. }\end{array}$ \\
\hline
\end{tabular}

For the purposes of this report, wildlife species will be considered significant if they have:

$\downarrow$ been designated as such by the Committee on the Status of Endangered Wildlife in Canada (COSEWIC 1998);

$\downarrow$ been included on the red-, blue-, or yellow-lists of species of concern within the province of Alberta (Alberta Environ. Prot. 1996);

$\downarrow$ been cited as being locally rare or uncommon in the province; or

$\downarrow$ been cited as being of relatively high abundance in the Saddle Hills region.

COSEWIC determines the national status of species, sub-species, and separate populations of native fish, amphibians, reptiles, birds, and mammals in Canada. COSEWIC has identified five risk categories for Canadian wildlife species, as follows (COSEWIC 1998):

Extinct - a species that no longer exists anywhere 
Extirpated - a species no longer existing in the wild in Canada but occurring elsewhere

Endangered - a species facing imminent extinction or extirpation

Threatened - a species likely to become endangered if limiting factors are not reversed

Vulnerable - a species of special concern because of characteristics that make it particularly sensitive to human activities or natural events.

Provincial populations of wildlife species in Alberta have also been evaluated, and their status classified based on the following categories (Alberta Environmental Protection 1996):

Red - species whose populations are nonviable or at immediate risk of declining to nonviable levels in Alberta. They have, or will be considered for, designation as Endangered Species in Alberta.

Blue - species which are also at risk but the threats that they face are less immediate. Particularly vulnerable to non-cyclical declines in population or habitat degradation.

Yellow - sensitive species which are not currently believed to be at risk. They may require special management to address concerns related to low natural populations, limited provincial distribution, or particular biological characteristics.

Subdivided into Yellow A and Yellow B categories:

Yellow A - species which merit extra attention because they have experienced long-term declines in numbers.

Yellow B - species naturally rare, with clumped distributions or associated with deteriorating or threatened habitats.

Green - species not considered to be at risk. Their populations are healthy and often widespread and key habitats are generally secure.

For this report, significant flora are defined as those plant species which have been recognized as rare in Alberta (with 5 or fewer collections) by Packer and Bradley (1984). Wallis et at (1987) and Argus and Pryor (1990) provided further information on the status of rare plants.

A map showing significant areas in the Saddle Hills was created at a scale of 1:20 000. 


\subsection{Identification of Sensitive Features}

Soils and landscape information collected during the course of detailed and reconnaissance surveys were used to assist in subsequent mapping of sensitive features. Parameters considered included soil type and texture, slope, topography, parent material and vegetation composition, among others. Sensitive features in the study area are shown at a scale of $1: 20,000$.

\subsection{Identification of Disturbance Features}

Disturbance features as determined by aerial photograph interpretation and background information were confirmed during the course of field studies. A map showing existing disturbance features was produced, at a scale of $1: 20,000$.

\subsection{Polygon Database Preparation}

A digital database was prepared which incorporated the key characteristics of each map polygon shown on Map 1, the Ecological Land Classification. The database was formatted in ABASE IV and was structured to be easily incorporated with spatial data files for future GIS analysis and presentation if required. As specified in the study Terms of Reference, the following fields were included in the database:

\section{Dominant landscape parameters:}

polygon number

ecosite

parent material

surficial expression

proportion of polygon

soil classification to subgroup level

slope class

drainage class

surface soil texture

subsurface soil texture

vegetation community type(s)

soil permeability class

depth to bedrock $(\mathrm{cm})$

depth to impermeable layer $(\mathrm{cm})$ 
depth to water table $(\mathrm{cm})$

surface rockiness class

surface stoniness class

shrink-swell potential class

potential frost action class

flood hazard class

Subdominant landscape parameters:

parent material

surface expression

proportion of polygon

soil classification to subgroup level

slope class

drainage class

surface soil texture

subsurface soil texture

vegetation community type(s)

Database codes follow the Canadian System of Soil Classification (Canada Soil Survey Committee 1987) for the following parameters:

- parent material

- surface expression

- slope classes

- soil drainage classes

- soil subgroup classification

- soil texture

Vegetation community type codes, potential frost action classes, surface rockiness classes and surface stoniness classes are defined in Appendices 1, 3, 4 and 5 respectively. 


\subsection{RESULTS}

\subsection{Ecological Land Classification}

The Ecological Land Classification of the study area is presented on Map 1 and the accompanying legend. The following is a key to the surficial materials present in the Saddle Hills study area:

$\begin{array}{ll}\text { F } & \text { Fluvial } \\ \text { FO } & \text { Fluvial and Organic complexes } \\ \text { GF } & \text { Glaciofluvial } \\ \text { GL } & \text { Glaciolacustrine } \\ \text { L } & \text { Lacustrine } \\ \text { MGL } & \text { Moraine and Glaciolacustrine complex } \\ \text { M } & \text { Moraine } \\ \text { MC } & \text { Moraine and Colluvium complex } \\ \text { MO } & \text { Moraine and Organic complex } \\ \text { O } & \text { Organic }\end{array}$

\subsection{Description of Vegetation Community Types}

Vegetation community development is influenced by annual temperature and precipitation regimes, as well as microsite variability in aspect, slope, moisture regime, salinity and other soil properties, and disturbance factors. In total, thirteen community types were identified within the study area. They are:

1. Aspen/prickly rose-low-bush cranberry/bluejoint

2. Aspen/prickly rose-low-bush cranberry/wild sarsaparilla

3. Aspen/prickly rose-snowberry/awnless brome-bluejoint

4. Aspen/Canada buffaloberry/bunchberry

5. Aspen-balsam poplar/green alder/bluejoint

6. Aspen-balsam poplar/red-osier dogwood-prickly rose

7. White spruce/bunchberry/feathermoss

8. Lodgepole pine-white spruce/common Labrador Tea/feathermoss

9. Lodgepole pine/green alder/bunchberry 
10. Black spruce-tamarack/common Labrador tea/Sphagnum moss

11. Bluejoint - beaked sedge / buck-bean

12. Miscellaneous Wetland Communities

13. Upland Shrubland

(1) Aspen/prickly rose-low-bush cranberry/bluejoint:

This is a mature to old seral community type characteristic of well to imperfectly drained, level to undulating midslope positions. Parent materials vary from coarse to fine textured, slightly to moderately stony morainal deposits to medium textured, non-stony glaciolacustrine deposits. Open stands of mature to overmature, lightly stocked aspen dominate the upper canopy of this community. Lesser amounts of balsam poplar also occur. Other minor tree species include white spruce, lodgepole pine and white birch, although white birch seldom reaches a height greater than 5 metres. Succession is to white spruce in the absence of disturbance.

Stand history affects structure and composition of this community. O'Leary and Downing (1986) suggested that the proportions of aspen and balsam poplar may change because of differing mortality. Aspen usually have a shorter life span than do balsam poplar, 120 years compared to 135 years. Without a nearby seed source, white spruce regeneration is extremely slow, and consequently with increasing age and mortality the canopy opens. This then allows shade-intolerant understory species such as fireweed and bluejoint to flourish (O'Leary and Downing 1986).

The tall shrub layer is dominated by willow (primarily Salix bebbiana and Salix glauca) and green alder, with prickly rose, low-bush cranberry and dewberry (Rubus pubescens) predominant in the low shrub layer. The forb layer is usually not as diverse as the shrub layer. Common fireweed (Epilobium angustifolium) is the only forb species that consistently occurs with high cover. Other common forbs include showy aster (Aster conspicuus), and pink wintergreen (Pyrola asarifolia). The graminoid layer is highly variable, with bluejoint being the only species typically occurring with greater than 10 percent cover. Moss and lichen cover is commonly low with stair-step moss (Hylocomium splendens) and studded leather lichen (Peltigera aphthosa) being the most common species. 


\section{(2) Aspen/prickly rose-low-bush cranberry/wild sarsaparilla:}

The successional status of this plant community varies within the study area from young seral to mature seral. It occurs on level to moderately sloping morainal and glaciolacustrine materials that are typically finetextured, although sites with coarse-textured materials are also found. Soils of this association vary, depending on drainage. The most common soils are Dark Gray and Orthic Gray Luvisols developed on moderately well to imperfectly drained sites. The moderately well-drained positions are dominated by Orthic and Eluviated Eutric Brunisiols while Gleysols (Rego Humic and Humic Luvic) generally occur on imperfectly to poorly drained sites. Other soils include Solonetzic and Brunisolic Gray Luvisols.

The canopy of this community is usually dominated by heavily stocked aspen. In some situations, however, balsam poplar is either dominant or co-dominant depending on stand age. Site-specific soil conditions including imperfect to poor drainage also favour balsam poplar growth. White spruce, lodgepole pine and white birch are the other minor tree species of the canopy. Regeneration of the above species is variable and dependent on site characteristics. This community is generally of fire origin and should eventually succeed to white spruce if a seed source is available.

The tall shrub layer of this community is not well developed. Combined cover over ten percent is rare, occurring only when there are significant breaks in the canopy. Various willows (Salix spp.), green alder and saskatoon tend to be associated with most sites. Prickly rose and low-bush cranberry dominate the low shrub layer.

A close relationship exists between this community and the Aspen/prickly rose - low-bush cranberry/bluejoint community type. The two communities differ in that the forb and graminoid layers of the Aspen/prickly rose - low-bush cranberry/wild sarsaparilla community usually show greater diversity. Common species include wild sarsaparilla, showy aster (Aster conspicuus), common fireweed and bluejoint. As the stand ages, however, and the aspen start to become decadent, bluejoint and common fireweed can be expected to increase dramatically. Thus, without a nearby seed source, the Aspen/prickly rose - low-bush cranberry/wild sarsaprilla association develops into the Aspen/prickly rose-low-bush cranberry/bluejoint association. 
(3) Aspen/prickly rose-snowberry/awnless brome-bluejoint:

This is the characteristic very young seral vegetation community type found on well to moderately well drained, level to moderately inclined slopes. It is associated with drier aspects and is commonly located adjacent to water courses throughout the area. Parent materials are primarily fluvial or glaciofluvial, although morainal sites do exist.

Two different phases of this community exist within the study area. A prickly rose-snowberry/awnless brome-bluejoint phase exists in areas that are frequently disturbed, such as those affected by periodic floods and fires. This phase has very little aspen cover, about $1 \%$ and only in the tall shrub layer. In areas not recently disturbed, aspen cover increases dramatically (up to 45\%) to form the Aspen/prickly rosesnowberry/awnless brome-bluejoint association. Lodgepole pine is also found in the tall shrub layer, but regeneration is primarily aspen.

The tall shrub layer is poorly developed with beaked willow (Salix bebbiana) being the only true tall shrub common on these sites. Prickly rose and snowberry (Symphoricarpos albus) dominate the low shrub layer of this community, but wild red raspberry (Rubus idaeus) and saskatoon are also common. The forb layer is highly variable and closely related to the density of aspen cover. As aspen cover increases, forb cover decreases. Common forbs include northern bedstraw (Galium boreale), wild vetch (Vicia americana) and common yarrow (Achillea millefolium). Awnless brome (Bromus inermis) and bluejoint typically dominate the graminoid layer, with 15 to $96 \%$ cover.

Both disturbance and edaphic conditions affect the development of this association. Periodic flooding and burning combined with rapid runoff and high evapotranspiration rates form conditions favourable for grassland vegetation. If disturbance is removed, aspen suckers are allowed to encroach, eventually forming a tree canopy. This reduces evapotranspiration causing grassland species to be out-competed and aspen to dominate. 


\section{(4) Aspen/Canada buffaloberry/bunchberry:}

This vegetation type occurs on well to moderately well drained morainal landforms throughout the study area. Topography varies from level to undulating. Soils are predominately Orthic Gray Luvisols with minor occurrences of Solonetzic and Dark Gray Luvisols. Aspen generally dominates a tree layer that includes lesser amounts of balsam poplar and white spruce. Amount of white spruce, the climax tree species, varies from site to site.

The shrub layer is generally diverse and well developed, with the most common species being Canada buffaloberry (Shepherdia canadensis), prickly rose, low-bush cranberry, white meadowsweet (Spiraea betulifolia), snowberry, bunchberry and dewberry. White meadowsweet generally increases with grazing intensity. Herbaceous vegetation is also diverse, although cover is variable depending on overstory density. Characteristic forbs include wild sarsaparilla, twinflower (Linnaea borealis), and wild lily-of-the-valley (Maianthemum canadense). Grass cover is variable with bluejoint and hairy wild rye (Elymus innovatus) being most common. Feathermoss cover is usually quite sparse.

\section{(5) Aspen-balsam poplar/green alder/bluejoint:}

This is a mature to old seral community type characteristic of moderately well to imperfectly drained, level to undulating upland positions. Parent materials consist of coarse to fine textured, slightly to moderately stony morainal deposits as well as coarse-textured, non-stony glaciolacustrine deposits. Orthic Gray Luvisols are the dominant soil type. Other soils include Orthic Dystric Brunisols, Humic Luvic Gleysols and Brunisolic and Dark Gray Luvisols. Aspen and balsam poplar co-dominate throughout these stands. Other tree species present in the canopy layer include white spruce, lodgepole pine and white birch. This community should eventually succeed to white spruce.

Green alder is prevalent in the tall shrub layer, with cover values ranging up to $75 \%$. Other tall shrubs present include beaked willow (Salix bebbiana) and pussy willow (Salix discolor). The low shrub layer is dominated by bracted honeysuckle (Lonicera involucrata) with lesser occurrences of prickly rose, wild red raspberry (Rubus idaeus), low-bush cranberry and bristly black currant (Ribes lacustre). Wild sarsaparilla and common fireweed are the most common species in a relatively diverse forb stratum. Grass cover is 
highly variable and tends to be affected by grazing intensity. Lightly grazed sites have a well developed graminoid layer consisting primarily of bluejoint. As grazing intensity increases, bluejoint cover decreases. The moss layer is absent at most sites, although stair-step moss (Hylocomium splendens) occurs infrequently. Reindeer lichen (Cladina mitis) and studded leather lichen (Peltigera aphthosa) can occasionally be found in minor amounts.

(6) Aspen-balsam poplar/red-osier dogwood-prickly rose:

This young to mature seral community type is found on moderately well to poorly drained undulating to inclined mid-slope terrain consisting of fine-textured morainal, glaciofluvial and glaciolacustrine materials. It can be described as having well-stocked stands of aspen and balsam poplar in the tree stratum.

In the shrub layer, prickly rose is dominant, with low-bush cranberry and red-osier dogwood as important associates. White spruce is an occasional species in the shrub layer, occurring in $29 \%$ of sampled sites. Common fireweed and tall lungwort (Mertensia paniculata) are generally present in greater abundance than other forb species. The graminoid layer, dominated by bluejoint, is variable in cover, occupying from 3 to $30 \%$ of the ground surface. The moss and lichen layer of this community is generally sparse.

(7) White spruce/bunchberry/feathermoss:

This climax community type is found on moderately well to imperfectly drained, fine textured soils developed on inclined to undulating morainal materials. Soils include Brunisolic and Orthic Gray Luvisols. This community type has a well-developed vertical structure. The tree layer is dominated by mature white spruce, often up to 25 metres in height. Lesser amounts of aspen, balsam poplar, black spruce and lodgepole pine also occur.

Common species include low-bush cranberry, common Labrador tea, prickly rose, Canada buffaloberry, bracted honeysuckle, bunchberry, bishop's-cap (Mitella nuda) and twinflower. Feathermosses, including stair-step moss (Hylocomium splendens), Schreber's moss (Pleurozium schreberi) and knight's plume moss (Ptilium crista-castrensis) often comprise a significant portion of the ground cover. Studded leather lichen (Peltigera aphthosa) is also common. 


\section{(8) Lodgepole pine-white spruce/common Labrador tea/feathermoss:}

This is a young to mature seral community type found on well-drained, level to gently undulating fine textured deposits. Sites typically occur on glaciolacustrine veneers and blankets over moraine and often occupy transitional lower to mid-slope sites between well-drained uplands and poorly drained organics. Soils are predominately Brunisolic Gray Luvisols and are usually classified as submesotrophic (somewhat deficient in nutrients). The overstory is generally dominated by lodgepole pine, and to a lesser degree white spruce. White spruce is usually more prevalent in the lower canopy because of its slower growth rate. Minor occurrences of other tree species such as black spruce, tamarack, aspen and balsam poplar also occur.

The shrub layer is dominated by common Labrador tea. Additional shrub cover is provided by prickly rose, beaked willow (Salix bebbiana), bracted honeysuckle, Canada buffaloberry, bunchberry, bog cranberry (Vaccinium vitis-idaea), and dwarf bilberry (Vaccinium caespitosum). The herb layer is generally poorly developed with low species diversity. Common species include twinflower and palmate-leaved coltsfoot (Petasites palmatus). Sedges (Carex spp.) dominate the graminoid layer while feathermosses generally form a continuous carpet on the forest floor.

\section{(9) Lodgepole pine/green alder/bunchberry:}

This is a young seral vegetation community type found on moderately well drained, undulating morainal materials. Soils are dominated by fine textured Orthic Gray Luvisols. The most common overstory species is lodgepole pine, generally greater than $20 \mathrm{~m}$ in height. Other associated tree species include aspen and balsam poplar.

The dominant component of the shrub layer is green alder. Other common shrub species include prickly rose, low-bush cranberry, bracted honeysuckle and white meadowsweet. Bunchberry is also relatively high in cover. Common forbs include common fireweed, stiff club-moss (Lycopodium annotinum) and wild sarsaparilla. Grass cover is moderate, with bluejoint the dominant species. Feathermoss cover is generally patchy and discontinuous, and the most common species are Schreber's moss and knight's plume moss. 
(10) Black spruce-tamarack/common Labrador tea/ sphagnum moss:

This maturing edaphic climax community is found sporadically throughout the study area, generally occurring on poorly to very poorly drained organic deposits overlying morainal clays. These are typically ombrogenous peatiand types, receiving water primarily from atmospheric precipitation, and as a result are mineral-poor. Black spruce is usually dominant in the tree layer but may be quite stunted and patchy in growth form. Tamarack may also be present as a minor overstorey component. Common Labrador tea is usually extensive in the shrub layer, often with basket willow (Salix petiolaris), and bog birch (Betula glandulosa). Palmate-leaved coltsfoot (Petasities palmatus), large northern aster (Aster modestus) and various sedges (Carex spp.) are generally the most common associated forbs and graminoids. Although Sphagnum mosses are prevalent, other moss species including Schreber's moss also occur.

(11) Bluejoint - beaked sedge/ buck-bean:

This community is common in frequently flooded lake basins and in mineral-rich peatlands generally referred to as fens. This association is less common in the study area than the Black spruce-tamarack/common Labrador tea/Sphagnum moss bog community. Vegetation is graminoid-dominated, with beaked sedge (Carex rostrata) and bluejoint the prevalent species. Forb species include buck-bean (Menyanthes trifoliata), marsh cinquefoil (Potentilla palustris), water arum (Calla palustris) and water-parsnip (Sium suave). Occasionally, low tree and shrub species occur, including white birch and pussy willow (Salix discolor).

\section{(12) Miscellaneous Wetland Communities}

There are numerous other minor community types within the Saddle Hills that were not field checked, and instead were identified by either aerial photography or reconnaissance plots. Miscellaneous wetland communities include sedge fen, cattail-sedge, and bog birch-willow/sedge/moss communities.

The sedge fen and cattail associations are common around the margins of frequently flooded lake basins and small wetlands with year-round high water tables. These communities are characterized by an extensive cover of graminoid species such as water sedge (Carex aquatilis), awned sedge (Carex atherodes) and bluejoint, interspersed with clumps of cattail (Typha latifolia) and bulrush (Scirpus spp.). Floating, sedge- 
dominated vegetation mats and small islands of floating vegetation commonly occur in the shallower, openwater portions of small water bodies in the study area. Common associated forb species include water arum (Calla palustris), buck-bean and water hemlock (Cicuta maculata).

The bog birch-willow/sedge/moss community often occurs in geogenous, minerotrophic peatlands generally referred to as fens, or in conjunction with black spruce-dominated bogs. The tree component of the bog birch-willow/sedge/moss community is sparse and is generally dominated by stunted tamarack with occurrences of black spruce. The shrub layer is not very diverse with the most common species being bog birch (Betula glandulosa), and willows (Salix spp.). Bryophytes of these communities are primarily brown mosses such as Aulacomnium palustre, Tomenthypnum nitens, Drepanocladus spp. and Plagiomnium spp., with patches of Sphagnum spp.

(13) Upland Shrubland

A Willow-alder shrubland community is found along the northern escarpment of the Saddle Hills. It is typically found on sites that have recently slumped, and many still show some signs of movement. A second shrubland type, a Snowberry-saskatoon community, occurs on south-facing slopes, such as along the Bad Heart River. This community has a wide diversity of forbs, including wild vetch (Vicia americana), northern bedstraw (Galium boreale), wild strawberry (Fragaria virginiana) and harebell (Campanula rotundifolia). The graminoid layer is dominated by slender wheat grass (Agropyron trachycaulum) and smooth brome.

\subsection{Forage Productivity}

The average 1996 productivity values for Saddle Hills vegetation community types are presented in Table 2. Total biomass (sum of dry weights of above-ground parts of grasses, forbs and low-growing shrubs) produced in Saddle Hills vegetation community types in 1996 varied from 90 to $2134 \mathrm{~kg} / \mathrm{ha}$ (Table 2). Graminoid biomass ranged from almost nil in the White spruce / bunchberry / feathermoss community type to an average of over $2099 \mathrm{~kg} / \mathrm{ha}$ in the Bluejoint-beaked sedge/buck-bean type. Appendix 6 gives dry weights of individual samples at each site.

The Bluejoint - beaked sedge / buck-bean community type produced the greatest biomass, nearly all of which 
consisted of grasses and sedges (Table 2). Stands of this type occur primarily in frequently flooded areas and in fens. Cattle access to these areas may be limited by the high water table, especially in periods of high precipitation.

The lowest biomass values occurred in two of the coniferous community types (\#7 White spruce/bunchberry/feathermoss and \#8 Lodgepole pine - white spruce/common Labrador tea/feathermoss).

In these mature seral to climax forests, shading of the forest floor by the closed canopy of mature trees minimized productivity of the forb and graminoid layers. The understory of these communities was dominated by a continuous carpet of feathermosses, sometimes associated with ericaceous shrubs.

Average 1996 production in the most extensive community type in the study area, the Aspen/prickly rose low-bush cranberry/bluejoint type, totalled $746 \mathrm{~kg} / \mathrm{ha}$. The majority of the clipped biomass from this community was represented by forbs (51\%), with $13 \%$ graminoids and $36 \%$ low-growing shrubs (Table 2 ). Although bluejoint occurred consistently in this community type, it was often secondary in cover to common fireweed.

We clipped all low-growing shrubs within the microplots. These forb-like woody plants, such as bunchberry and twinflower (Linnaea borealis), vary in forage value for cattle or wildlife. Also, some of the measured forage productivity values for all layers may be lower than actual values since there was evidence of recent livestock grazing at some sites. 
Table 2.

Average forage productivity of vegetation community types in the Saddle Hills study area in 1996.

\begin{tabular}{|c|c|c|c|c|c|}
\hline \multicolumn{2}{|r|}{ Saddle Hills Vegetation Community Type } & \multicolumn{4}{|c|}{ Average Productivity $(\mathrm{kg} / \mathrm{ha})$} \\
\hline & & Gram. ${ }^{1}$ & Forb & Shrubs & TOTAL \\
\hline 1 & $\begin{array}{l}\text { Aspen/prickly rose - low-bush cranberry/bluejoint } \\
(\mathrm{n}=25)^{*}\end{array}$ & 94 & 381 & 270 & 746 \\
\hline 2 & $\begin{array}{l}\text { Aspen/prickly rose- low-bush cranberry / wild } \\
\text { sarsaparilla }(n=20)\end{array}$ & 43 & 313 & 214 & 570 \\
\hline 3 & $\begin{array}{l}\text { Aspen/prickly rose-snowberry/awnless brome- } \\
\text { bluejoint }(n=2)\end{array}$ & 646 & 685 & 126 & 1457 \\
\hline 4 & Aspen/Canada buffaloberry/bunchberry $(n=16)$ & 74 & 255 & 252 & 582 \\
\hline 5 & Aspen-balsam poplar/green alder/bluejoint $(n=16)$ & 70 & 271 & 374 & 714 \\
\hline 6 & $\begin{array}{l}\text { Aspen-balsam poplar/red-osier dogwood-prickly } \\
\text { rose }(n=12)\end{array}$ & 103 & 360 & 323 & 786 \\
\hline 7 & White spruce/bunchberry/feathermoss $(n=4)$ & $<1$ & 108 & 75 & 183 \\
\hline 8 & $\begin{array}{l}\text { Lodgepole pine-white spruce/common Labrador tea } \\
\text { / feathermoss }(n=1)\end{array}$ & 19 & 49 & 22 & 90 \\
\hline 9 & Lodgepole pine/green alder/bunchberry $(n=1)$ & 16 & 368 & 97 & 481 \\
\hline 10 & $\begin{array}{l}\text { Black spruce-tamarack/common Labrador tea / } \\
\text { Sphagnum moss }(n=1)\end{array}$ & 331 & 146 & 287 & 764 \\
\hline 11 & Bluejoint -beaked sedge / buck-bean $(n=1)$ & 2099 & 34 & 0 & 2134 \\
\hline 13 & Upland shrubland $(\mathrm{n}=1)$ & 152 & 580 & 359 & 1092 \\
\hline
\end{tabular}

* n - number of sites sampled; Miscellaneous wetland communities (Type 12) were not sampled;

${ }^{1}$ Gram. - graminoids 


\subsection{Significant Features}

Significant features of the Saddle Hills study area are summarized below. Significant sites or areas deserving special mention are identified on Map 2, with a detailed discussion of each presented below and in Section 5.0 .

\subsubsection{Significant Geological/Landform Features}

The most significant geological feature of the study area is the steep escarpment that forms the northern extremity of the Saddle Hills (Map 2). This escarpment is formed by the bedrock dipping slightly towards the south and represents the only significant elevation change found in the region. It also provides habitat for a wintering elk (Cervus canadensis) population (Alberta Fish and Wildlife Division 1985a, D. Hervieux, personal communication).

The Bad Heart River valley is also a significant landform feature. This valley provides habitat for numerous wildlife species including mule deer (Odocoileus hemionus), white-tailed deer (Odocoileus virginianus), elk (Cervus canadensis), and black bear (Ursus americanus). Its south-facing valley walls support a variety of grassland and shrubland communities.

\subsubsection{Significant Hydrological Features}

The most prominent hydrological feature of the Saddle Hills study area is the Bad Heart River and its tributaries. This river supports the only substantial fish population in the area (Alberta Fish and Wildlife Division 1985b, TERA Environmental Consultants 1993). Other important hydrological features include Kleskun Creek and tributaries, Braeburn Creek and other tributaries of the Saddle (Burnt) River, and Mulligan Creek, Grande Prairie Creek and numerous unnamed creeks of the Bear River drainage.

Hilltop Lake is also a significant hydrologic feature found within the study area (Map 2). It represents the largest lake and the only one utilized by waterfowl to any extent. It also provides a key recreational resource for the surrounding human population. 


\subsubsection{Significant Historic and Archaeological Features}

At least one historic site and eight prehistoric sites are known to exist within the study area (Alberta Forestry, Lands and Wildlife 1987). The extreme sensitivity of these sites prevent them from being included in the Significant Features map with this report. Although no major surveys have been conducted in this area, there is a high likelihood that additional sites exist. Because of this, Alberta Forestry, Lands and Wildlife (1987) has rated the archaeological resource sensitivity of this area as high.

The archaeological sites in the area represent the remains of numerous prehistoric hunting and gathering cultures that have frequented the area for the past 12000 years or more. Most of the recorded archaeological sites have been related to the exploitation of the wildlife resources. These sites include small hunting and fishing camps and tool remains.

Site specific archaeological investigations are currently conducted in conjunction with the referral process for petroleum development applications.

\subsubsection{Significant Palaeontological Features}

Although no palaeontological sites are recorded within the study area, there is a high probability of their presence. The area adjacent to the Bad Heart River and the tributaries of the Saddle (Burnt) River are specifically rated as high (Tyrell Museum of Palaeontology 1984).

\subsubsection{Significant Flora}

No rare plant species were recorded in the Saddle Hills study area during the biophysical inventory fieldwork in 1995. This does not mean that rare plant species do not occur within the study area. Successful identification of rare plant populations is best accomplished through intensive survey methods designed to achieve this purpose. The biophysical survey methodology employed during 1995 field work, the timing of the survey (late August) in relation to plant species' phenology and the relatively low sampling intensity reduced the chances of locating rare plant populations. Another factor influencing the detection of rare plants is that species may be evident in one year but not in another due to drought or other climatic factors. 
A number of rare plant species predicted to occur within the Saddle Hills study area were identified as part of a study by TERA Environmental Consultants Ltd. (1993), for the nearby CONWEST Exploration Company Ltd. Sexsmith Gas Plant. A list of rare flora found near or within the Saddle Hills study area is given in Appendix 7.

\subsubsection{Significant Fauna}

Table 3 presents a list of Saddle Hills fauna considered to be at risk in Canada or within the province. One mammal species, the wolverine (Gulo gulo), has been designated by the Committee on the Status of Endangered Wildlife in Canada as nationally 'vulnerable', because of characteristics that make it particularly sensitive to human activities or natural events (COSEWIC 1998). On a provincial scale, blue-listed species include three mammal and one bird species; four mammal and eight bird species are yellow A- or B-listed (Alberta Environ. Prot. 1996) (refer to Section 3.0 for ranking definitions and criteria).

Human impacts leading to habitat loss, over-exploitation, and non-native species introduction do not affect all species equally. At greatest risk are species with small populations, species with fluctuating population levels, and species with slow rates of population growth. Thus, certain wildlife species in the Saddle Hills present more of a conservation concern than others. Table 4 lists groups of organisms that are particularly susceptible to disturbance and extinction (Terborgh 1974, Pimm et al. 1988, Reid and Miller 1989, Orians and Kunin 1990).

Some Saddle Hills wildlife, not designated as rare, are here included in the category of significant fauna based on a combination of the criteria listed in Table 4. The viability of these species is considered representative of ecosystem integrity, and their conservation necessary to preserve biological diversity. The following species or species assemblages, though not at risk, are considered significant within the Saddle Hills study area: elk (Cervus canadensis), moose (Alces alces), certain furbearers, raptors, woodpeckers and many songbirds. 
Table 3. Rare fauna of the Saddle Hills region, Alberta.

\begin{tabular}{lll}
\hline & SPECIES & $\begin{array}{l}\text { Provincial / National } \\
\text { Conservation Status }\end{array}$ \\
\hline northern long-eared bat & Myotis septentrionalis & Blue-listed in Alberta \\
\hline northern flying squirrel & Glaucomys sabrinus & Yellow B-listed in Alberta \\
\hline grizzly bear ${ }^{2}$ & Ursus arctos & Blue-listed in Alberta \\
\hline fisher & Martes pennanti & Yellow B-listed in Alberta \\
\hline long-tailed weasel & Mustela frenata & Yellow A-listed in Alberta \\
\hline wolverine & Gulo gulo & Designated by COSEWIC as \\
& & vulnerable in Canada \\
\hline Canada lynx & & Blue-listed in Alberta \\
\hline horned grebe & Lynx canadensis & Yellow B-listed in Alberta \\
\hline trumpeter swan & Podiceps auritus & Yellow A-listed in Alberta \\
\hline bald eagle & Cygnus buccinator & Blue-listed in Alberta \\
\hline northern harrier & Haliaeetus leucocephalus & Yellow B-listed in Alberta \\
\hline sharp-tailed grouse & Circus cyaneus & Yellow A-listed in Alberta \\
\hline great gray owl & Tympanuchus phasianellus & Yellow A-listed in Alberta \\
\hline pileated woodpecker & Strix nebulosa & Yellow B-listed in Alberta \\
\hline western tanager & Dryocopus pileatus & Yellow B-listed in Alberta \\
\hline clay-coloured sparrow & Piranga ludovicianus & Yellow B-listed in Alberta \\
\hline & Spizella pallida & Yellow A-listed in Alberta \\
\hline
\end{tabular}

${ }^{1}$ Refer to Section 3.0 above for ranking definitions and criteria

${ }^{2}$ presence in Saddle Hills considered extralimital 
Table 4. Organisms Susceptible To Local Extinction Processes.

\section{GROUP OF ORGANISM}

Species at higher trophic levels

\section{DESCRIPTION}

Species high in the food chain tend to be large, rare animals with slow rates of population growth.

Local endemics

Species with restricted ranges are often threatened by habitat loss, as exemplified by the high rate of island species extinction.

Species with chronically small populations

Largest members of a guild

Species with poor dispersal and colonization ability

Species with colonial nesting habits

Migratory or nomadic species
This category overlaps the first. Since many species at higher trophic levels have sparsely distributed populations, habitat restriction or fragmentation may reduce their populations to extremely low levels. However, the population sizes of species at lower trophic levels may also be low in a given habitat or region.

Physically large species have high metabolic demands, require large habitats, and tend to occur in low densities. Thus, the largest species within a guild tend to be at higher risk than smaller species.

As with local endemics, species with narrow habitat requirements and species which cannot disperse easily to new habitats are at risk even if their population is widespread.

Colonial nesting species are particularly susceptible to over-exploitation or potential loss of breeding habitat.

Migratory species are dependant upon suitable habitat in both their summer and winter ranges and along their migratory routes. Nomadic, or far-ranging species, require large tracts of wilderness areas and the potential for adverse effects of habitat changes on these populations is high.

These species' populations fluctuate greatly and they face increased threats when their population is low.

\subsubsection{Significant Mammal Species}

Based on geographic distributions identified by Smith (1993), the Saddle Hills study area is anticipated to provide habitat for almost 50 mammal species, many of which are large game species of extreme economical, ecological, and aesthetic value (Appendix 8). Seven mammal species of concern are predicted to occur in the study area (Table 3).

A broad range of furbearing animals inhabit the Saddle Hills. Of the 18 species of furbearers in the Saddle Hills, four species, the fisher, wolverine, long-tailed weasel and Canada lynx, are recognized as species of concern within the province (Table 3; Alberta Environ. Prot. 1996). Trapping harvests of fisher have continued to decline since 1985 (Alberta Environ. Prot. 1996). This species prefers climax coniferous forests, especially in the vicinity of watercourses (Banfield 1974). According to Alberta Environ. Prot. (1996), the current wolverine population size in Alberta is estimated at less than 1000 individuals. Habitat 
loss is cited as the likely cause of declines of wolverines, long-tailed weasels and Canada lynx (Alberta Environ. Prot. 1996).

The river otter is a species which reaches the southern limits of its range near the Saddle Hills. Previously designated as "blue-listed", the species has been de-listed (Alberta Environ. Prot. 1996). However, the species is considered significant, due to an inherently scarce population. Also, river otters' requirements for clean, unpolluted, non-impacted habitats and their intolerance of human disturbances further complicates their active conservation in Alberta, particularly in severely impacted areas such as the Saddle Hills.

\subsubsection{Significant Avifauna}

Nine bird species of the Saddle Hills are recognized as species of concern (Table 3). This includes two species dependent on wetlands, three birds of prey, and several species of forested habitats.

The potential presence of trumpeter swans (Cygnus buccinator) in the study area warrants considerable attention. The exact status of trumpeter swan habitat use in the Saddle Hills is not known, but potential nesting habitat exists in the study area. Trumpeter swans usually prefer shallow, isolated productive lakes or wetlands characterized by emergent vegetation (Semenchuk 1992) often with beaver activity. Alternatively, Saddle Hills may support dispersing breeding or non-breeding individuals from adjacent wetlands. An individual trumpeter swan was recorded on an unnamed wetland in the study area during field work in the summer of 1995 . It is unlikely that this observation represents a breeding pair, however.

Among resident birds of prey of the Saddle Hills area, the bald eagle (Haliaeetus leucocephalus) and great gray owl are the most significant species. The bald eagle represents a unique management challenge to resource planners and land users. It formerly nested throughout Alberta but breeding is now restricted largely to northern portions of the province (Semenchuk 1992). While the exact status of bald eagles in Alberta is not known, the species has been yellow B-listed in Alberta (Alberta Environ. Prot. 1996). Raptors such as bald eagle are exceptionally susceptible to disturbance during nesting, and their nest sites should be protected wherever possible.

The great gray owl is a naturally scarce species distributed widely across appropriate forested habitats in 
Alberta. Great gray owls are designated as Yellow B-listed in Alberta (Alberta Environ. Prot. 1996). They nest in forested habitats and exhibit a preference for mature and older forest stands (Bull and Henjum 1990, Duncan 1992, Habeck 1994).

Of the six species of woodpeckers anticipated to nest in the Saddle Hills area (Appendix 8), one species, the pileated woodpecker (Dryocopus pileatus), has been designated at risk (Table 3). Pileated woodpeckers, as well as other species of woodpeckers, are ecologically important components of the Saddle Hills boreal forest habitats, as they are primary excavators of one or more nest or roost cavities per year. Management for protection of the pileated woodpecker and its nesting sites would concomitantly benefit many other wildlife species. Nesting cavities are often abandoned by woodpeckers after the young fledge, allowing numerous other cavity-dependent wildlife species to inhabit old and unused woodpecker cavities. Secondary cavity-nesters in the Saddle Hills area that are unable to excavate their own cavities include swallows, bluebirds, kestrels, flycatchers, and a few ducks and owls. Northern flying squirrel, a yellow B-listed mammal (Alberta Environ. Prot. 1996) and pine marten also utilize woodpecker cavities extensively. Quinlan et al. (1990) identified approximately 40 vertebrate species that are associated with the habitat typically used by three-toed and hairy woodpeckers.

Upland nesting waterfowl species such as bufflehead (Bucephala albeola) and common goldeneye ( $B$. clangula) species prefer to nest in tree cavities excavated by flickers (Colaptes spp.), within $200 \mathrm{~m}$ of a wetland (Gauthier and Smith 1987). Maintenance of a mosaic of wetlands and mixedwood forests in close association are required for such species.

Aspen mixedwood forests support one of the most diverse communities of breeding songbirds in North America (Robbins et al. 1989), and this forest type is widespread throughout the Saddle Hills. There is much physiographic variation within the Saddle Hills study area, provided by the interspersion of grassland, aspen groves, mixedwood forests, and coniferous stands. Complexity, both of the forest strata and of the forest mosaic, is the key to diversity of avian community structure in aspen mixedwood forests. 


\subsubsection{Significant Fauna by Community Type}

Since vegetation cover type is actually an expression of a variety of biophysical conditions such as soil, aspect and relief, it generally offers a valid prediction of habitat suitability for many wildlife species. As an aid in understanding potential wildlife use, Table 5 interprets vegetation community types as "habitat types" for selected significant fauna in the Saddle Hills. 


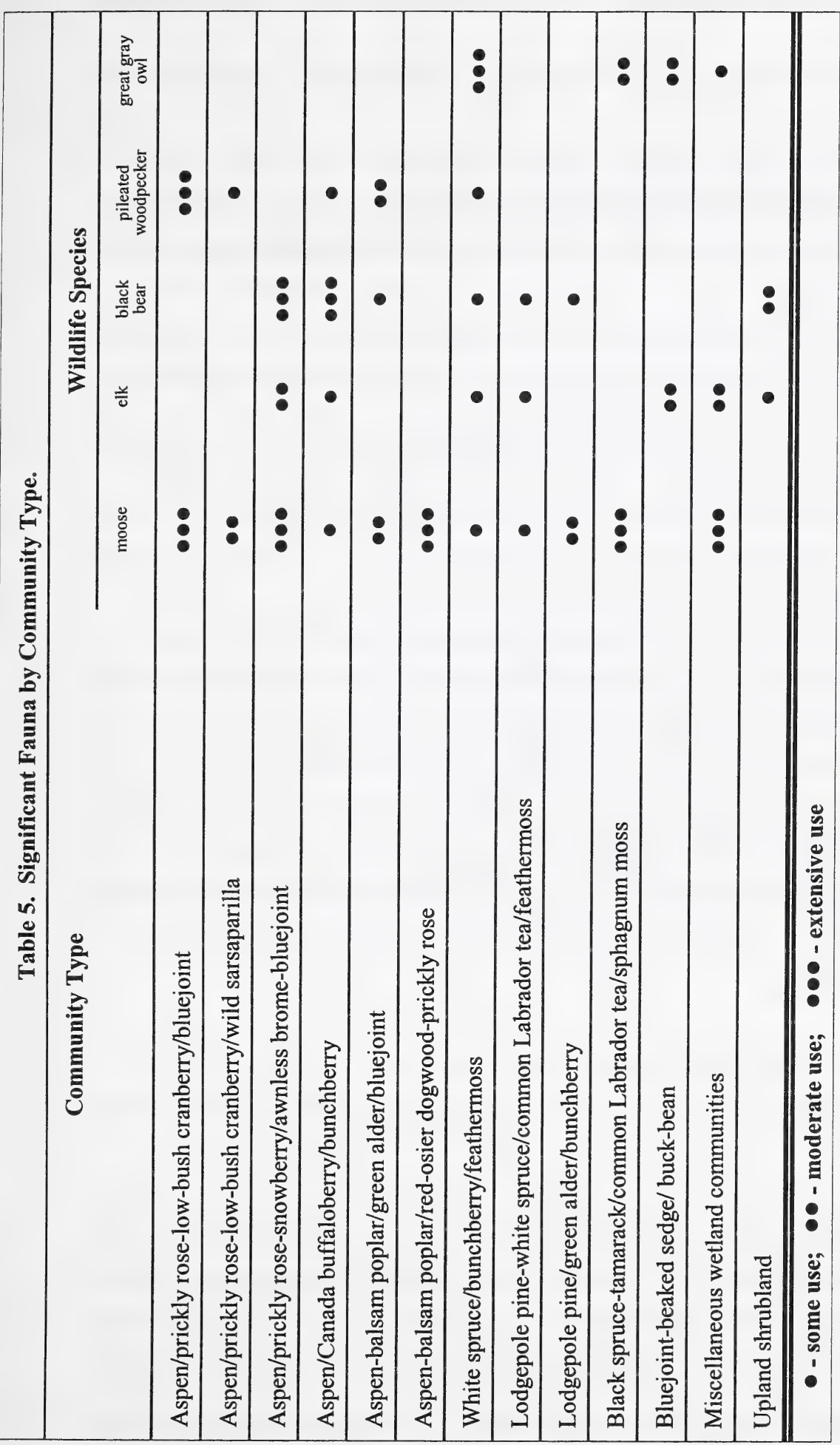




\subsubsection{Significant Sites/Areas}

Wetlands are dispersed throughout the study area, occurring particularly in association with the drainage of the Bad Heart River. A high diversity of wildlife species can be found in these complexes. The significance of suitable wetlands may be high due to disproportionate levels of use in relation to their occurrence.

The Bad Heart River and its tributaries, the numerous wetland complexes associated with the Bad Heart River drainage, and the Bear River tributaries are considered environmentally significant areas because of their potential to provide winter habitat for moose (CLI 1973, Alberta Fish and Wildlife Division 1985a). These areas, along with the northern escarpment of the Saddle Hills themselves and the Saddle (Burnt) River valley immediately north of the study area, also provide much of the wintering habitat for the regional elk population.

Significant elk habitats in the Saddle Hills are areas that provide critical resources, such as food, winter thermal cover or summer calving habitat. In winter, elk in Alberta utilize saskatoon and aspen (Morgantini 1979), willow (Salix spp.), rose (Rosa sp.), red-osier dogwood, bog birch, and low-bush cranberry (Stelfox 1980). However, snow depth and condition affect elk access to food sources (Morgantini and Hudson 1983). Elk therefore select sites protected by topography or vegetation from strong winds, snow crusting and snow drifting in winter and early spring. Within the Saddle Hills, such sites are often found in large, linear riparian areas such as the Bad Heart River valley and its adjacent uplands. Mineral licks have also been identified by Alberta Fish and Wildlife Services as significant sources of nutrients for all ungulates in the area (Alberta Fish and Wildlife Division 1985a).

Riparian areas such as Grande Prairie Creek and Kleskun Creek valleys, and tributaries to the Bear River in the southern portion of the study area, also perform critical linking functions for deer travelling between agricultural and forested lands.

The development of a network of roads and trails which has accompanied most types of human activity in the Saddle Hills impacts ungulate populations in a number of ways, including providing hunter access to previously inaccessible populations. While land reclamation can improve productivity of elk by providing quality forage (Fargey and Hawley 1989), it has also been suggested that the negative impacts of increased 
access significantly reduce net habitat utilization (Smith 1985, Christensen et al. 1993, Unsworth et al. 1993).

The following is a summary of some of the significant sites identified in the Saddle Hills study area. Each significant area is outlined on Map 2, and represented by a map code number (Site No.). Key features of each site are listed below, and in Section 5.0.

\section{Regionally Significant Sites}

\begin{tabular}{||l|l||}
\hline \multicolumn{1}{|c|}{ Site/Area Name } & \multicolumn{1}{|c|}{ Key Features } \\
\hline \hline $\begin{array}{l}\text { Bad Heart River } \\
\text { (Site No. 1) }\end{array}$ & $\begin{array}{l}\text { - important elk production and winter range } \\
\text { - acts as an corridor for many wildlife species } \\
\text { - key fisheries habitat } \\
\text { - important habitat for many plant and wildlife species } \\
\text { - significant hydrologic and landform feature }\end{array}$ \\
\hline $\begin{array}{l}\text { North Escarpment } \\
\text { (Site No. 3) }\end{array}$ & - regionally significant geologic feature \\
& - most significant elevation change in the region \\
& - important elk winter range \\
\hline
\end{tabular}




\section{Locally Significant Sites}

\begin{tabular}{|c|c|}
\hline Site/Area Name & Key Features \\
\hline $\begin{array}{l}\text { Saddle (Burnt) River } \\
\text { Tributaries } \\
\text { (Site No. 5) }\end{array}$ & $\begin{array}{l}\text { - key ungulate habitat } \\
\text { - acts as an corridor for many wildlife species } \\
\text { - key fisheries habitat } \\
\text { - important habitat for many plant and wildlife species } \\
\text { - significant hydrologic and landform feature }\end{array}$ \\
\hline $\begin{array}{l}\text { Bear River Tributaries } \\
\text { (Site No. 4) }\end{array}$ & $\begin{array}{l}\text { - key ungulate habitat } \\
\text { - acts as an corridor for many wildlife species } \\
\text { - key fisheries habitat } \\
\text { - important habitat for many plant and wildlife species } \\
\text { - significant hydrologic and landform feature }\end{array}$ \\
\hline $\begin{array}{l}\text { Kleskun Creek Tributaries } \\
\text { (Site No. 2) }\end{array}$ & $\begin{array}{l}\text { - key ungulate habitat } \\
\text { - acts as an corridor for many wildlife species } \\
\text { - key fisheries habitat } \\
\text { - important habitat for many plant and wildlife species } \\
\text { - significant hydrologic and landform feature }\end{array}$ \\
\hline $\begin{array}{l}\text { Hilltop Lake } \\
\text { (Site No.6) }\end{array}$ & $\begin{array}{l}\text { - locally significant hydrologic feature } \\
\text { - key recreational resource }\end{array}$ \\
\hline
\end{tabular}




\subsection{Sensitive Features}

Environmental sensitivity ratings are often used as an evaluation of the performance of a site in response to various land uses or disturbance types (Bentz and Saxena 1993, O'Leary et al. 1993). Disturbances occurring on lands with a low sensitivity rating can easily be remedied by standard operating procedures. Conversely, other lands may be more sensitive to disturbance because they possess at least one of the following characteristics (Bentz and Saxena 1993):

- a very high susceptibility to erosion;

- severe limitations to revegetation; or

- distinctive, rare or unusual landforms, wildlife populations or plant communities that are regionally, provincially, nationally or internationally important.

The identification of sensitive features encompasses the overlaying of three mapping themes, specifically, vegetation community types, significant features and slope class. This method is consistent with that developed for previous sensitive areas studies (Bradshaw et al. 1994, 1995; Bruhjell et al. 1996). The resulting polygons are then evaluated and classified according to the following classes:

High:

The disturbance can be expected to result in a complete loss of the significant natural feature or require major mitigation and very restrictive operating conditions to maintain the vital ecological functions of the feature or the site. Site reclamation would be expected to be very difficult, and the potential for the site to be successfully reclaimed would be anticipated to be low.

Moderate: The disturbance will result in considerable loss or modification of the significant natural feature. Significant mitigation and restrictive operating conditions are likely required to maintain the vital ecological functions of the feature.

Low: The disturbance will result in minor loss or modification to the significant natural feature. Some mitigation and normal operating restrictions may be required to maintain the long term viability and vitality of the feature.

Insignificant: The disturbance will have no measurable impact on the significant ecological feature.

The Saddle Hills study area as a whole is considered to be of low to moderate sensitivity due to subtle slopes and the lack of distinctive, rare or unusual landforms. However, some areas within the study area can be considered more fragile than others. This difference is presented in Map 3 as a rating of the sensitivity of 
sites to physical disturbance, defined here as the degree of anticipated negative effects, usually as caused by water erosion, if the ground cover is disturbed (such as by petroleum exploration activities).

Highly sensitive areas within the study area include the northern escarpment, Hilltop Lake and other larger bodies of water and adjacent shorelines, and the valleys of Bad Heart River, tributaries of Kleskun Creek, Saddle (Burnt) River and Bear River (Map 3). Most of the water bodies within the study area are classified as highly sensitive. These sites support significant fauna species. The sites are susceptible to water erosion due to steep slopes and fine textures.

Disturbance to either the water course itself or adjacent land units increases the sediment loading of these water bodies which in turn affects both aquatic flora and fauna. Also, disturbances adjacent to water bodies also lower their value as wildlife corridors.

Moderately sensitive sites occur throughout the area and were generally delineated by slope and soil texture (Map 3). Major portions of the study area consist of gently undulating, fine textured morainal materials, and are classified as being of low sensitivity.

\subsection{Disturbance Features}

Disturbance features encompass those sites or areas where the impact of man's activities are readily observed from aerial photography and the ground. Preliminary disturbance features mapping was accomplished through the interpretation of 1:30 000 (1989) black and white aerial photographs, 1:20 000 (1995) orthophoto mosaics and 1:50 000 (1992) Provincial Resource Base Maps. Disturbance features included, but were not limited to:

- Access Development:

- Agricultural:

- Industrial:
- including improved roads, unimproved roads and trails

- including annual croplands, improved pastures, cattle watering holes (dugouts), farm residences and fencelines

- including active and reclaimed wellsites, pipelines, right-of-ways, major transmission lines and industrial facility sites

The impact of human activity on the Saddle Hills is readily observed from both the ground and from aerial 
photographs. For the most part, agricultural disturbances are confined to the boundaries of the study area, while linear and industrial disturbances in the form of trails, cutlines, pipelines, gravel and paved roads are spread evenly throughout the study area. These disturbance features are depicted in Map 4. Surface disturbance and subsequent weed invasion is associated with all of the disturbance types listed above. 


\subsection{CHECKLISTS OF SIGNIFICANT FEATURES}

The following are checklists and further descriptions of mappable significant features identified in the Saddle Hills study area. Locations of these sites are presented in Map 2. As well, an overall sensitivity rating is given for each site or feature.

The significant features checklists are grouped by level of significance, from regional to local significance. 


\section{Site Name: Bad Heart River}

Site Location: dissecting the study area

\section{Description:}

The site includes the valley slopes associated with the Bad Heart River and its tributaries, and associated floodplains.

\section{Significance: $\quad$ Regional}

- significant hydrologic and landform feature

- important elk (Cervus canadensis) production and winter range

- acts as an corridor for many wildlife species

- key fisheries habitat

- economically important fish species include Arctic grayling (Thymallus arcticus), lake white fish (Coregonus clupeaformis), northern pike (Esox lucius), walleye (Stizostedion vitreum) and burbot (Lota lota)

- south facing slopes provide habitat for regionally significant grassland and shrubland communities that include species such as northern wheat grass (Agropyron dasystachyum), slender wheat grass (Agropyron trachycaulum), western wheat grass (Agropyron smithii), bastard toadflax (Comandra umbellata) and harebell (Campanula rotundifolia)

\section{Sensitivity: High}

\section{Comments:}

- agricultural encroachment on riparian vegetation

\section{References:}

- 1995 field investigations

- D. Hervieux, pers. comm

- D.A. Westworth \& Associates Ltd. (1992)
- Key Wildlife Area Maps (1985)

- Fisheries Resources Map (1985)

- Van Waas (1972) 


\section{Site Name: Northern Escarpment}

Site Location: dissecting the northern portion of the study area

\section{Description:}

The unit consists of a north facing slope formed by the southern incline of the local bedrock. It occurs in the northern section of the study area and marks the northern extremity of the Saddle Hills.

\section{Significance: $\quad$ Regional}

- regionally significant geologic feature

- most severe elevation change in the region

- important elk (Cervus canadensis) winter range

\section{Sensitivity: High}

\section{Reference:}

- 1995 field investigations

- D. Hervieux, pers. comm.

- Van Waas (1972) 


\section{Site Name: $\quad$ Saddle (Burnt) River Tributaries}

Site Location: northern portion of the study area

\section{Description:}

The site includes tributaries of the Saddle (Burnt) River including Braeburn Creek.

\section{Significance: Local}

- key ungulate habitat

- acts as an corridor for many wildlife species

- key fisheries habitat

- important habitat for many plant and wildlife species

- significant hydrologic feature

\section{Sensitivity: High}

\section{Comments:}

- agricultural encroachment on riparian vegetation

\section{References:}

- 1995 field investigations

- Wildlife Key Area Maps (1985)

- Van Waas (1972) 


\section{Site Name: Bear River Tributaries}

Site Location: southwest portion of the study area

\section{Description:}

The site includes tributaries of the Bear River including Grande Prairie and Mulligan Creeks.

Significance: $\quad$ Local

- key ungulate habitat

- acts as an corridor for many wildlife species

- key fisheries habitat

- important habitat for many plant and wildlife species

- significant hydrologic feature

Sensitivity: High

\section{Comments:}

- agricultural encroachment on riparian vegetation

\section{References:}

- 1995 field investigations

- Wildlife Key Area Maps (1985)

- Van Waas (1972) 


\section{Site Name: Kleskun Creek Tributaries}

Site Location: southeast portion of the study area

\section{Description:}

The site includes tributaries of Kleskun Creek.

\section{Significance: Local}

- key ungulate habitat

- acts as an corridor for many wildlife species

- key fisheries habitat

- important habitat for many plant and wildlife species

- significant hydrologic feature

Sensitivity:

High

\section{Comments:}

- agricultural encroachment on riparian vegetation

\section{References:}

- 1995 field investigations

- Wildlife Key Area Maps (1985)

- Van Waas (1972) 


\section{Site Name: Hilltop Lake}

Site Location: located in parts of NE 20 \& SE 29 - Twp.75 - Rge.7 - W6M

\section{Description:}

The site is a locally significant hydrologic feature and includes an on-site campground and day use area.

Significance:

\section{Local}

- key recreational resource

- the site represents the only significant lake community found within the Saddle Hills study area

- the only waterfowl habitat that is used to any extent in the study area

\section{Sensitivity: High}

\section{References:}

- 1995 field investigations

- Van Waas (1972) 


\subsection{DATA GAPS}

The identification of significant features, particularly of rare flora and fauna, relied heavily on review of existing information as field time allocated for the project was insufficient to conduct the intensive surveys required to identify populations in the field. Extrapolation was often required of data from studies in areas adjacent to the Saddle Hills study area. This study will therefore be best used as an initial source to "flag" potential areas of concern related to any proposed resource development activity. Detailed field study will be required to confirm site-specific occurrences of significant flora and fauna within the study area. 


\subsection{LITERATURE CITED}

Achuff, P.L. 1994. Natural regions, subregions and natural history themes of Alberta, a classification for Protected Areas management. Prep. for Parks Services, Alberta Environ. Prot. 72 pp.

Alberta Environmental Protection. 1993. Alberta plants and fungi - master species list and species group checklists. Pub. No.: Ref. 75.

Alberta Environmental Protection. 1994. Ecological land survey site description manual. Canadian Forest Service and Alberta Land and Forest Services. Edmonton, AB. 165 pp.

Alberta Environmental Protection. 1996. The status of Alberta wildlife. Wildlife Manage. Div., Natural Resources Serv., Alberta Environ. Prot. Publ. No. I/620. Edmonton. 44 pp.

Alberta Fish and Wildlife Division. 1985a. Wildlife Key Area Maps (1:250,000 scale) - 83M. Alberta Forestry, Lands and Wildlife, Fish and Wildlife Division. Edmonton, AB.

Alberta Fish and Wildlife Division. 1985b. Fisheries Resource Maps (1:250,000 scale) - 83M. Alberta Forestry, Lands and Wildlife, Fish and Wildlife Division. Edmonton, AB.

Alberta Fish and Wildlife Division. 1996. Unpublished trapper harvest data for mapsheet 83M. Alberta Environmental Protection, Fish and Wildlife Division. Edmonton, AB.

Alberta Forestry, Lands and Wildlife. 1987. Archaeological resource sensitivity zones. Resource Evaluation and Planning Division. Edmonton, AB. map.

Argus, G.W. and K.M. Pryer. 1990. Rare vascular plants in Canada: our natural heritage. Canadian Museum of Nature, Ottawa. 191 pp. + maps.

Banfield, A.W.F. 1974. The mammals of Canada. Univ. of Toronto Press, Toronto. 438 pp.

Bentz, J.A and A. Saxena. 1993. Significant ecological features inventory of the Lesser Slave Lake Integrated Resource Planning Area. Prepared for Resource Information Division, Alberta Environmental Protection, Edmonton, Alberta by Geowest Environmental Consultants Ltd., Edmonton, Alberta. 128 pp.

Bradshaw, D.A., A. Saxena and T. Normand. 1995. Biophysical overview, significant, sensitive and disturbance features of the Purple Springs Sensitive Area. Prepared by Geowest Environmental Consultants Ltd. for Alberta Environmental Protection. Edmonton, AB.

Bradshaw, D.A., A. Saxena, D.J. O'Leary, and J.A. Bentz. 1994. Biophysical overview, significant, sensitive, and disturbance features of the Lost River Sensitive Area. Prepared by Geowest Environmental Consultants Ltd. for Alberta Environmental Protection. Edmonton, AB.

Bruhjell, D.R., J.A. Bentz, R. Shultz and A. Saxena. 1996. Biophysical and significant ecological features of the Kootenay Plains Ecological Reserve. Prepared by Geowest Environmental Consultants Ltd. for Alberta Environmental Protection. Edmonton, AB. 
Bull, E.L. and M.G. Henjum. 1990. Ecology of the great gray owl. United States Department of Agriculture, Forest Service. Gen. Tech. Rep. PNW-265. Pacific Northwest Forest Experiment Station. Portland, OR.

Canada Soil Survey Committee, Subcommittee on Soil Classification. 1987. The Canadian system of soil classification. Can. Dep. Agric. Publ. 1646. Supply and Services Canada,Ottawa. 164 pp.

CLI (Canada Land Inventory). 1971. Land capability for wildlife - waterfowl. 1:250,000 scale map for 83M. Canada Land Inventory. Ottawa, ON.

CLI (Canada Land Inventory). 1973. Land capability for wildlife - ungulates. 1:250,000 scale map for 83M. Canada Land Inventory. Ottawa, ON.

Christensen, A.G., L.J. Lyon, and J.W. Unsworth. 1993. Elk management in the Northern Region: Considerations in forest plan updates or revisions. United States Department of Agriculture, Forest Service. Gen. Tech. Rep. INT-303. Intermountain Research Station. Ogden, UT. 10 pp.

COSEWIC. 1998. Canadian species at risk, April 1998. Committee on the Status of Endangered Wildlife in Canada. Ottawa, Ontario. $21 \mathrm{pp}$.

D.A. Westworth \& Associates Ltd. 1992. An overview of potential forest harvesting impacts on fish and fish habitat in the northern boreal forests of Canada's Prairie Provinces. Prepared for Alberta Forestry, Lands and Wildlife. Edmonton, $\mathrm{AB}$.

Duncan, J.R. 1992. Influence of prey abundance and snow cover on great gray owl breeding dispersal. Ph.D. Thesis. University of Manitoba. Winnipeg, MB.

Eagles, P. 1984. The Planning and Management of Environmentally Sensitive Areas. Longman: London and New York.

Environment Canada. 1993. Canadian climate normals, 1961- 1990. Atmospheric Environ. Service, Ottawa.

Fargey, P.J. and A.W.L. Hawley. 1989. Seasonal patterns of forage selection by wapiti (Cervus elaphus) in relation to land reclamation. AECV89-R3. Alberta Environmental Centre. Vegreville, AB. 112 pp.

Gauthier, G. and J.N.M. Smith. 1987. Territorial behavior, nest site availability, and breeding density in bufflehead. J. Anim. Ecol. 56: 171-184.

Habeck, J.R. 1994. Dynamics of forest communities used by great gray owls. Pages 176-201 in: Hayward, G.D. and J. Verner (eds). Flammulated, Boreal, and Great Gray Owls in the United States: A Technical Conservation Assessment. United States Department of Agriculture, Forest Service. Gen. Tech. Rep. RM-253. Rocky Mountain Forest and Range Experiment Station. Fort Collins, CO.

Morgantini, L.E. 1979. Habitat selection and resource division among bighorn sheep, elk, and mule deer in western Alberta. M.Sc. Thesis. University of Alberta. Edmonton, AB. 
Morgantini, L.E. and R.J. Hudson. 1983. Nutritional significance of altitudinal migrations for wapiti. Agric. For. Bull. 62: 109-112.

Moss, E.H. 1983. Flora of Alberta. Second edition. Revised by J.G. Packer. University of Toronto Press: Toronto. $687 \mathrm{pp}$.

Nelson, J.S. and M.J. Paetz. 1992. The Fishes of Alberta. 2nd Edition. University of Alberta Press. Edmonton, $\mathrm{AB}$.

Odynsky, W.M., J.D. Lindsay, S.W. Reeder and A. Wynnyk. 1961. Reconnaissance soil survey of the Beaverlodge and Blueberry Mountain sheets. Research Council of Alberta, Rep. No. 20. 123 pp. + maps.

Odynsky, W.M. and J.D. Newton. 1959. Soil survey of the Rycroft and Watino sheets. Research Council of Alberta. Report No. 56.84 pp. + maps.

O'Leary, D., J. Bentz, D. Ealey and A. Schwabenbauer. 1993. Inventory of environmentally sensitive and significant natural areas, City of Edmonton. Prepared for Planning and Development, City of Edmonton by Geowest Environmental Consultants Ltd., Edmonton, Alberta. 299 pp.

O'Leary, D. and D. Downing. 1986. Integrated Resource Inventory of the Grande Prairie County West study area. Alberta Forestry, Lands and Wildlife; Resource Evaluation and Planning Branch. Edmonton, AB.

Orians, G.H. and W. Kunin. 1990. Ecological uniqueness and the loss of species. In: Proc. of the Lake Wilderness Conf. on the Cons. of Genetic Resources. University of Washington Press. Seattle, WA.

Packer, J.G. and C.E. Bradley. 1984. A checklist of the rare vascular plants in Alberta. Provincial Museum of Alberta Natural History Occasional Paper No. 5. Alberta Culture. 112 pp.

Pimm, S.L. H.L. Jones, and J. Diamond. 1988. On the risk of extinction. Amer. Naturalist 132: 757-785.

Quinlan, R.W., W.A. Hunt, K. Wilson, and J. Kerr. 1990. Habitat requirements of selected wildlife species in the Weldwood Forest Management Agreement Area. Alberta Forestry, Lands and Wildlife; Fish and Wildlife Division. Hinton, AB. 189 pp.

Reid, W.V. and K.R. Miller. 1989. Keeping Options Alive: The Scientific Basis for Conserving Biodiversity. World Resources Institute. Gland, Switzerland. 128 pp.

Robbins, C.S., D.K. Dawson, and B.A. Dowell. 1989. Habitat area requirements of breeding forest birds of the middle Atlantic States. Wildl. Monogr. 103: 1-34.

Russell, A. and A. Bauer. 1993. The Amphibians and Reptiles of Alberta. University of Calgary Press. Calgary, AB.

Semenchuk, G.P. 1992. The Atlas of Breeding Birds of Alberta. Federation of Alberta Naturalists. Edmonton, AB. 390 pp. 
Smith, H.C. 1993. Alberta Mammals: An Atlas and Guide. Provincial Museum of Alberta. Edmonton, AB. 239 pp.

Smith, K. 1985. A preliminary elk (Cervus elaphus) management plan for the Edson Wildlife Management Area. Alberta Energy and Natural Resources, Fish and Wildlife Division. Edson, AB.

Stelfox, J.G. 1980. Nutritive value and preference ratings of common big game browse plants in Alberta. Unpubl. Rep. Canadian Wildlife Service. Edmonton, AB. 8 pp.

Strong, W.L. 1992. Ecoregions and ecodistricts of Alberta. Volume 1. Prepared by Ecological Land Surveys Ltd. for Alberta Forestry, Lands and Wildlife, Edmonton. Pub. No. T/244. 77 pp. + map.

Terborgh, J. 1974. Preservation of natural diversity: the problem of extinction-prone species. BioScience 24: 715-722.

TERA Environ. Consultants. 1993. Environmental impact assessment for the Conwest Exploration Company Limited Sexsmith Gas Plant. TERA Environmental Consultants Ltd.

Tyrell Museum of Palaeontology. 1984. Palaeontological resource sensitivity zones. Alberta Bureau of Surveying and Mapping. map.

United States Army Corps of Engineers. 1962. Pavement design for frost conditions. Engineering Manual 1110-1-306. United States Army Corps of Engineers. Washington, DC.

Unsworth, J.W., L. Kuck, M.D. Scott, and E.O. Garton. 1993. Elk mortality in the Clearwater drainage of northcentral Idaho. J. Wildl. Manage. 57(3): 495-502.

Van Waas, C. 1972. Saddle Hills land use plan. Alberta Department of Lands and Forests. Edmonton, AB. 66 pp. + maps.

Wallis, C., C. Bradley, M. Fairbarns and V. Loewen. 1987. The rare flora of Alberta. Volume 3: Species summary sheets. Alberta Forestry, Lands and Wildlife, Edmonton. Publ. No. T/155. 
APPENDIX 1. Vegetation community type codes used in the polygon database.

CODE

1. Aspen/prickly rose-low-bush cranberry/bluejoint

2. Aspen/prickly rose-low-bush cranberry/wild sarsaparilla

3. Aspen/prickly rose-snowberry/awnless brome-bluejoint

4. Aspen/Canada buffaloberry/bunchberry

5. Aspen-balsam poplar/green alder/bluejoint

6. Aspen-balsam poplar/red-osier dogwood-prickly rose

7. White spruce/bunchberry/feathermoss

8. Lodgepole pine-white spruce/common Labrador Tea/feathermoss

9. Lodgepole pine/green alder/bunchberry

10. Black spruce-tamarack/common Labrador tea/Sphagnum moss

11. Bluejoint - beaked sedge / buck-bean

12. Miscellaneous Wetland Communities

13. Upland Shrubland 
APPENDIX 2. Latin names of plant species mentioned in this report.

COMMON NAME

LATIN NAME

Trees:

Aspen

Populus tremuloides

Balsam fir

Abies balsamea

Balsam poplar

Populus balsamifera

Black spruce

Picea mariana

Lodgepole pine

Pinus contorta

Tamarack

Larix laricina

White spruce

Picea glauca

Shrubs:

Basket willow

Salix petiolaris

Beaked willow

Salix bebbiana

Bog birch

Betula glandulosa

Bog cranberry

Vaccinium vitus-idaea

Bracted honeysuckle

Bristly black current

Lonicera involucrata

Ribes lacustre

Bunchberry

Cornus canadensis

Canada buffaloberry

Shepherdia canadensis

Common Labrador tea

Ledum groenlandicum

Dewberry

Rubus pubescens

Dwarf bilberry

Vaccinium caespitosum

Green alder

Alnus crispa

Low-bush cranberry

Viburnum edule

Prickly rose

Pussy willow

Rosa acicularis

Red-osier dogwood

Salix discolor

Saskatoon

Smooth willow

Cornus stolonifera

Amelanchier alnifolia

Salix glauca

Snowberry

Symphoricarpos albus

Twinflower

Linnaea borealis

White meadowsweet

Spiraea betulifolia

Wild red raspberry

Willow

Rubus idaeus

Salix spp.

Mosses and Lichens

Brown moss

Drepanocladus spp.

Golden moss

Tomenthypnum nitens

Knight's plume moss

Ptilium crista-castrensis

Reindeer lichen

Cladina mitis

Schreber's moss

Pleurozium schreberi

Sphagnum moss

Sphagnum spp.

Stair-step moss

Hylocomium spendens

Studded leather lichen

Peltigera aphthosa

Tufted moss

Aulacomnium palustre 
APPENDIX 2. (Cont'd)

Forbs and allies

Bastard toadflax

Comandra umbellata

Bishop's-cap

Mitella nuda

Buck-bean

Menyanthes trifoliata

Common pink wintergreen

Common cattail

Pyrola asarifolia

Common yarrow

Typha latifolia

Common fireweed

Maiathemum canadense

Harebell

Epilobium angustifolium

Large northern aster

Campanula rotundifolia

Marsh cinquefoil

Aster modestus

Northern bedstraw

Potentilla palustris

Palmate-leaved coltsfoot

Galium boreale

Showy aster

Petasites palmatus

Stiff club-moss

Aster conspicuus

Tall lungwort

Locopodium annotinum

Mertensia paniculata

Water-hemlock

Circuta maculata

Water parsnip

Sium suave

Water arum

Calla palustris

Wild strawberry

Fragaria virginiana

Wild sarsaparilla

Aralia nudicaulus

Wild vetch

Vicia americana

Graminoids:

Awned brome

Bromus inermis

Awned sedge

Carex atherodes

Beaked sedge

Bluegrass

Carex rostrata

Poasp.

Bluejoint

Calamagrostis canadensis

Bulrush

Scirpus spp.

Hairy wild rye

Elymus innovatus

Melic grass

Melica sp

Northern wheat grass

Agropyron dasystachyum

Sedge

Carex $s p$

Slender wheat grass

Agropyron trachycaulum

Water sedge

Carex aquatilis

Western wheat grass

Agropyron smithii

Wheat grass

Agropyron spp 


\section{APPENDIX 3. Frost Design Classification.}

Adapted from United States Army Corps of Engineers (1962)

\begin{tabular}{|c|c|c|c|c|}
\hline $\begin{array}{l}\text { Frost } \\
\text { Group }\end{array}$ & Kind of Soil & $\begin{array}{c}\text { \% by weight, } \\
\text { finer than } \\
0.02 \mathrm{~mm}\end{array}$ & $\begin{array}{l}\text { Typical Soil } \\
\text { Types (USCS) }\end{array}$ & $\begin{array}{c}\text { Typical Soil } \\
\text { Textures } \\
\text { (CSSC) }\end{array}$ \\
\hline $\mathrm{F} 1$ & Gravelly soils & $3-10$ & $\begin{array}{c}\mathrm{GW}, \mathrm{GP}, \mathrm{GW}-\mathrm{GM}, \mathrm{GP}- \\
\mathrm{GM}\end{array}$ & g \\
\hline \multirow[t]{2}{*}{ F2 } & Gravelly soils & $10-20$ & GM,GW-GM,GP-GM & $\mathrm{g}, \mathrm{gL}$ \\
\hline & sands & $3-15$ & $\begin{array}{l}\text { SW,SP,SM,SW- } \\
\text { SM,SP-SM }\end{array}$ & $\mathrm{S}, \mathrm{IS}, \mathrm{cS}$ \\
\hline \multirow[t]{3}{*}{ F3 } & Gravelly soils & over 20 & GM,GC & $\mathrm{gL}, \mathrm{gC}$ \\
\hline & $\begin{array}{l}\text { Sands except very fine } \\
\text { silty sands }\end{array}$ & over 15 & SM,SC & LS \\
\hline & Clays, P.I. $>12$ & - & $\mathrm{CL}, \mathrm{CH}$ & $\mathrm{C}, \mathrm{SiC}, \mathrm{L}$ \\
\hline \multirow[t]{4}{*}{$\mathrm{F} 4$} & All silts & - & $\mathrm{ML}, \mathrm{MH}$ & $\mathrm{Si}, \mathrm{SiL}, \mathrm{SiC}$ \\
\hline & Very fine silty sands & over 15 & SM & fSI,vfS \\
\hline & Clays P.I. $>12$ & - & CL,CL-ML & $\mathrm{SC}, \mathrm{SiCL}$ \\
\hline & $\begin{array}{l}\text { Varved clays and } \\
\text { otehr fine grained, } \\
\text { banded sediments }\end{array}$ & - & $\begin{array}{l}\text { CL \& ML; CL,ML } \\
\text { \&SM; CL,CH \&ML; } \\
\text { CL,CH,ML \& SM }\end{array}$ & $\begin{array}{c}\text { L \& CL;CL,L } \\
\& S L ; C L, C ~ \& L ; \\
\text { CL,C,L \& SL }\end{array}$ \\
\hline
\end{tabular}




\section{APPENDIX 4. Rockiness Classes.}

Rockiness is recorded as classes based on the percentage of surface occupied by exposed bedrock.

\begin{tabular}{||l|c|}
\hline \multicolumn{1}{|c|}{ ROCKINESS } & SURFACE OCCUPIED BY BEDROCK (\%) \\
\hline Non-rocky & $<2$ \\
\hline Slightly rocky & $2-10$ \\
\hline Moderately rocky & $10-25$ \\
\hline Very rocky & $25-50$ \\
\hline Exceedingly rocky & $50-90$ \\
\hline
\end{tabular}

Definitions:

Rocky 0. Non-rocky land - bedrock exposure covers less than 2 percent of the surface and is more than $100 \mathrm{~m}$ apart. There is minor interference with tillage.

Rocky 1. Slightly rocky land - sufficient bedrock exposures to interfere with tillage but not to make intertilled crops impracticable. Depending on how the pattern affects tillage, rock exposures are roughly $35-100 \mathrm{~m}$ apart and cover $2-10 \%$ of the surface, depending on the pattern.

Rocky 2. Moderately rocky land - sufficient bedrock exposures to make tillage of intertilled crops impractical, but soil can be worked for hay crops or improved pasture if other soil characteristics are favourable. Rock exposures are roughly $10-35 \mathrm{~m}$ apart and cover $10-25 \%$ of the surface, depending on the pattern.

Rocky 3. Very rocky land - sufficient rock outcrop to make use of machinery impractical, except for light machinery where other soil characteristics are especially favourable for improved pasture. The land may have some use for wild pasture or forests, depending on other soil characteristics. Rock exposures or patches of soil covering too thinly over rock for use, are roughly $3.5-10 \mathrm{~m}$ apart and cover $25-50 \%$ of the surface, depending on the patterns.

Rocky 4. Exceedingly rocky land - sufficient rock outcrops (or very thin soil over rock) to make all use of machinery impractical. The land may have some value for poor pasture or forests. Rock outcrops are $3.5 \mathrm{~m}$ or less apart and cover $50-90 \%$ of the area. 


\section{APPENDIX 5. Surface Stoniness Classes. ${ }^{1}$}

Adapted from Canada Soil Survey Committee (1987)

\begin{tabular}{|c|c|}
\hline Stoniness Class & Description \\
\hline Stony 0 & $\begin{array}{l}\text { non-stony phase - very few stones }(<0.01 \% \text { of surface, } \\
\text { stones }>30 \mathrm{~m} \text { apart) }\end{array}$ \\
\hline Stony 1 & $\begin{array}{l}\text { slightly stony phase - some stones that hinder cultivation } \\
\text { slightly or not at all }(0.01-3 \% \text { of surface, stones } 10-30 \mathrm{~m} \\
\text { apart) }\end{array}$ \\
\hline Stony 2 & $\begin{array}{l}\text { moderately stony phase - enough stones to cause some } \\
\text { interference with cultivation }(0.1-3 \% \text { of surface, stones } 2 \text { - } \\
10 \mathrm{~m} \text { apart })\end{array}$ \\
\hline Stony 3 & $\begin{array}{l}\text { very stony phase - sufficient stones to handicap cultivation } \\
\text { seriously; some clearing is required (3-15\% of surface, } \\
\text { stones } 1-2 \mathrm{~m} \text { apart) }\end{array}$ \\
\hline Stony 4 & $\begin{array}{l}\text { exceedingly stony phase - sufficient stones to prevent } \\
\text { cultivation until considerable clearing is done (15-50\% of } \\
\text { surface, stones } 0.1-0.5 \mathrm{~m} \text { apart) }\end{array}$ \\
\hline Stony 5 & $\begin{array}{l}\text { excessively stony phase - too stony to permit cultivation; } \\
\text { boulder or stone pavement ( }>50 \% \text { of surface, stones }<0.1 \\
\text { m apart) }\end{array}$ \\
\hline
\end{tabular}

${ }^{1}$ Phases of stoniness are defined on the basis of the percentage of the land surface occupied by fragments coarser than $15 \mathrm{~cm}$ in diameter. 
APPENDIX 6. Weights of vegetation clipped from range quadrats at survey sites in the Saddle Hills, July 1996.

\begin{tabular}{|c|c|c|c|c|c|c|c|}
\hline $\begin{array}{l}\text { Site } \\
\text { No. }\end{array}$ & $\begin{array}{l}\text { Grass } \\
(\mathrm{gm})\end{array}$ & $\begin{array}{l}\text { Forbs } \\
\text { (gm) }\end{array}$ & $\begin{array}{l}\text { Shrubs } \\
(\mathrm{gm})\end{array}$ & $\begin{array}{l}\text { Site } \\
\text { No. }\end{array}$ & $\begin{array}{l}\text { Grass } \\
(\mathrm{gm})\end{array}$ & $\begin{array}{l}\text { Forbs } \\
\text { (gm) }\end{array}$ & $\begin{array}{l}\text { Shrubs } \\
\text { (gm) }\end{array}$ \\
\hline 1 & 0.1 & 28 & 5.7 & 27 & 37.3 & 35.2 & 2.3 \\
\hline 2 & $\mathrm{n} / \mathrm{a}$ & 33.5 & 22 & 28 & 5.4 & 31 & 12.9 \\
\hline 3 & 6.9 & 37.9 & 12.6 & 29 & 3.5 & 2.2 & 8.8 \\
\hline 4 & 3.6 & 22.7 & 56.7 & 30 & 3.6 & 7.6 & 28.9 \\
\hline 5 & 9.6 & 12.6 & 39.8 & 31 & 1.8 & 41.2 & 13.7 \\
\hline 6 & 26.1 & 11.5 & 22.6 & 32 & 0 & 0 & 7.4 \\
\hline 7 & 2.1 & 19.8 & 30 & 33 & 0.1 & 18.3 & 11 \\
\hline 8 & 0 & 19.1 & 10.4 & 34 & 25 & 12 & 20.2 \\
\hline 9 & 1.1 & 23.3 & 15 & 35 & 4.9 & 18.1 & 10.5 \\
\hline 10 & 0 & 18 & 40.8 & 36 & 11.7 & 17 & 37.2 \\
\hline 11 & 0.2 & 5.7 & 44.2 & 37 & 2.2 & 12 & 18 \\
\hline 12 & $\mathrm{n} / \mathrm{a}$ & 14.5 & 22.7 & 38 & 0.1 & 19.6 & 15.3 \\
\hline 13 & 3.9 & 22.6 & 8.9 & 39 & 5.3 & 15.9 & 57.2 \\
\hline 14 & 2.1 & 17.9 & 14.4 & 40 & 10.9 & 20.7 & 47.6 \\
\hline 15 & 0.6 & 29.1 & 8.6 & 41 & 9.6 & 34.7 & 23.1 \\
\hline 16 & 0.1 & 25.9 & 26.3 & 42 & 11 & 15.7 & 12.1 \\
\hline 17 & 0.9 & 12.8 & 23 & 43 & 6.9 & 14.4 & 17.6 \\
\hline 18 & 1.2 & 11.4 & 19.9 & 44 & 0.1 & 28.7 & 10.5 \\
\hline 19 & 0 & 40.5 & 22.2 & 45 & 5.7 & 23.3 & 10.2 \\
\hline 20 & 0.1 & 22.2 & 45.7 & 46 & 0.1 & 58.8 & 27.1 \\
\hline 21 & 0.1 & 40.4 & 1.8 & 47 & 0.1 & 20.6 & 18 \\
\hline 22 & $\mathrm{n} / \mathrm{a}$ & 15.6 & 16.7 & 48 & 96.9 & 107.8 & 0.1 \\
\hline 23 & 0 & 29.3 & 54.3 & 49 & 0.1 & 13.5 & 4.5 \\
\hline 24 & 13 & 6.1 & 22.3 & 50 & 0.1 & 30.5 & 6.8 \\
\hline 25 & 1.6 & 26.8 & 15.4 & 51 & 165.3 & 2.7 & $\mathrm{n} / \mathrm{a}$ \\
\hline 26 & 8.9 & 6.5 & 50.5 & 52 & 9 & 12.5 & 10.3 \\
\hline $\begin{array}{l}\text { Plot } \\
\text { No. }\end{array}$ & $\begin{array}{l}\text { Grass } \\
\text { (gm) }\end{array}$ & $\begin{array}{l}\text { Forbs } \\
\text { (gm) }\end{array}$ & $\begin{array}{l}\text { Shrubs } \\
\text { (gm) }\end{array}$ & $\begin{array}{l}\text { Plot } \\
\text { No. }\end{array}$ & $\begin{array}{l}\text { Grass } \\
\text { (gm) }\end{array}$ & $\begin{array}{l}\text { Forbs } \\
\text { (gm) }\end{array}$ & $\begin{array}{l}\text { Shrubs } \\
\text { (gm) }\end{array}$ \\
\hline
\end{tabular}




\begin{tabular}{|r|c|c|c|c|c|c|c|c|}
\hline 53 & 4.9 & 14 & 11.6 & & 81 & 24.9 & 24.8 & 11.6 \\
\hline 54 & 1.5 & 3.9 & 1.7 & & 82 & 23.6 & 14 & 10.9 \\
\hline 55 & 1.7 & 41.6 & 14.2 & & 83 & 3 & 12.7 & 8.1 \\
\hline 56 & 10.5 & 12.8 & 20.5 & & 84 & 5 & 38.3 & 20.3 \\
\hline 57 & 23.7 & 62.9 & 7.9 & & 85 & 1.3 & 29 & 7.6 \\
\hline 58 & 2.5 & 8.4 & 10 & & 86 & 18.3 & 38.7 & 24.3 \\
\hline 59 & 0.1 & 13.9 & 12 & & 87 & 1.8 & 69.8 & 18.5 \\
\hline 60 & 0 & 6.3 & 21.7 & & 88 & 0.1 & 33.3 & 8.5 \\
\hline 61 & 4.2 & 12.2 & 5.2 & & 89 & 0.1 & 46.6 & 46.4 \\
\hline 62 & 5.9 & 19.7 & 11.8 & & 90 & 2.2 & 31.9 & 16.5 \\
\hline 63 & 15.6 & 27 & 29.5 & & 91 & 12.8 & 27.8 & 13.2 \\
\hline 64 & 41.7 & 13.3 & 10.5 & & 92 & 0.1 & 4 & 11.4 \\
\hline 65 & 4.5 & 39 & 20.3 & & 93 & $\mathrm{n} / \mathrm{a}$ & 13.7 & 43.5 \\
\hline 66 & 5.3 & 38.8 & 27 & & 94 & 17.8 & 20.2 & 48.5 \\
\hline 67 & 4.8 & 0.1 & 19.7 & & 95 & 2.7 & 58.8 & 43.3 \\
\hline 68 & 12 & 45.7 & 28.3 & & 96 & 0.1 & 5.2 & 12.6 \\
\hline 69 & 0.6 & 23.5 & 21 & & 97 & 0.8 & 21.2 & 4.2 \\
\hline 70 & 0 & 32 & 37.9 & & 98 & 0.2 & 22.9 & 90.7 \\
\hline 71 & 3.7 & 68 & 11.3 & & 99 & 5.4 & 32.5 & 39.1 \\
\hline 72 & 11.5 & 44.6 & 18.5 & & 100 & 0 & 8.3 & 63.5 \\
\hline 73 & 5.6 & 51.6 & 24.6 & & & & & \\
\hline 74 & 11 & 24.6 & 1.9 & & & & & \\
\hline 75 & $\mathrm{n} / \mathrm{a}$ & 33.8 & 37.3 & & & & & \\
\hline 76 & 10.4 & 31.9 & 0.1 & & & & & \\
\hline 77 & 1.8 & 29.5 & 12.5 & & & & & \\
\hline 78 & 7.6 & 26.2 & 11.2 & & & & & \\
\hline 79 & 1 & 34.1 & 8.1 & & & & & \\
\hline 80 & 0 & 1.5 & 1.3 & & & & & \\
\hline \hline & & & & & & & & \\
\hline \hline
\end{tabular}

n/a - data not available 
APPENDIX 7. Rare plant species which may occur in the Saddle Hills study area ${ }^{1}$.

\begin{tabular}{|c|c|c|c|}
\hline SPECIES & Common Name & Habitat & Alberta Status ${ }^{2}$ \\
\hline Aster umbellatus & $\begin{array}{l}\text { Flat-topped White } \\
\text { Aster }\end{array}$ & $\begin{array}{l}\text { Moist woods, thickets \& } \\
\text { meadows }\end{array}$ & Rare \\
\hline Cardamine pratensis & Meadow Bitter Cress & Bogs and swamps & Rare \\
\hline Carex adusta & Browned Sedge & $\begin{array}{l}\text { Dry acid soil; moist sandy } \\
\text { ground under pine; stony } \\
\text { ground }\end{array}$ & Unknown \\
\hline Carex lacustris & Lake Sedge & Marshes \& swampy woods & Unknown \\
\hline Carex loliacea & Rye-grass Sedge & Marshes \& sphagnum bogs & Rare \\
\hline Carex trisperma & Three-seeded Sedge & Bogs \& wet woods; muskeg & Rare \\
\hline Carex vulpinoidea & Fox Sedge & Swampy ground & $\begin{array}{l}\text { Abundance } \\
\text { Unknown }\end{array}$ \\
\hline Danthonia spicata & Poverty Oat Grass & $\begin{array}{l}\text { Dry to moist open areas \& } \\
\text { open woodland }\end{array}$ & $\begin{array}{l}\text { Abundance } \\
\text { Unknown }\end{array}$ \\
\hline Eleocharis compressa & Flattened Spike-rush & Sandy shores \& marshy ground & $\begin{array}{l}\text { Abundance } \\
\text { Unknown }\end{array}$ \\
\hline Eupatorium maculatum & Joe Pye-weed & Wet meadows \& thickets & Locally Common \\
\hline Geranium carolinanum & $\begin{array}{l}\text { Carolina Wild } \\
\text { Geranium }\end{array}$ & $\begin{array}{l}\text { Dry rocky woods, disturbed } \\
\text { sites }\end{array}$ & Rare \\
\hline Juncus brevicaudatus & Short-tailed Rush & $\begin{array}{l}\text { Shores \& marshes; pioneer on } \\
\text { wet ground }\end{array}$ & Locally Common \\
\hline Luzula acuminata & Wood Rush & Moist woodland, clearings & Rare or Overlooked \\
\hline Malaxis monophylla & $\begin{array}{l}\text { White Adder's- } \\
\text { mouth }\end{array}$ & Damp woods, banks \& bogs & Rare \\
\hline Monotropa hypopitys & Pine-sap & $\begin{array}{l}\text { Moist woods; saprophytic in } \\
\text { coniferous woods }\end{array}$ & Rare \\
\hline Nymphara tetragona & $\begin{array}{l}\text { Small White Water- } \\
\text { lily }\end{array}$ & Ponds and quiet waters & Rare \\
\hline Oryzopsis canadensis & Canadian Rice Grass & Open woods $\&$ hillsides & Locally Common \\
\hline Oryzopis micrantha & $\begin{array}{l}\text { Little-seed Rice } \\
\text { Grass }\end{array}$ & $\begin{array}{l}\text { Dry open areas \& rocky slopes; } \\
\text { sandy woodlands }\end{array}$ & Locally Common \\
\hline Polygala paucifolia & Fringed Milkwort & Marshy coniferous woods & Rare \\
\hline
\end{tabular}


Biophysical and Significant Ecological Features

\begin{tabular}{|c|c|c|c|}
\hline $\begin{array}{l}\text { Potemogeton } \\
\text { obtusifolius }\end{array}$ & $\begin{array}{l}\text { Blunt-leaved } \\
\text { Pondweed }\end{array}$ & $\begin{array}{l}\text { Lakes \& springs; cold springs, } \\
\text { streams }\end{array}$ & Rare \\
\hline Potamogeton robbinsii & Robbins Pondweed & Shallow water; shield Lakes & Rare or Overlooked \\
\hline $\begin{array}{l}\text { Rhynchospora } \\
\text { capillacea }\end{array}$ & Slender Beak-rush & Calcareous bogs & $\begin{array}{l}\text { Abundance } \\
\text { Unknown }\end{array}$ \\
\hline Sagittaria latifolia & $\begin{array}{l}\text { Broad-leaved } \\
\text { Arrowhead }\end{array}$ & Ponds \& Lakes & $\begin{array}{l}\text { Abundance } \\
\text { Unknown }\end{array}$ \\
\hline Scirpus clintonii & Clinton's Bulrush & Marshy ground \& turfy shores & $\begin{array}{l}\text { Local \& Not } \\
\text { Uncommon }\end{array}$ \\
\hline Scirpus cyperinus & Wool-grass & Marshy ground & $\begin{array}{l}\text { Abundance } \\
\text { Unknown }\end{array}$ \\
\hline Selaginella rupestris & Little Club-moss & $\begin{array}{l}\text { Dry open areas; exposed sandy } \\
\text { sites }\end{array}$ & Locally Common \\
\hline Viola selkirkii & Great-spurred Violet & Moist woods & Very Local \\
\hline Woodsia glabella & Smooth Woodsia & $\begin{array}{l}\text { Moist calcareous rocks \& } \\
\text { shaded cliffs }\end{array}$ & Rare \\
\hline
\end{tabular}

1. Species List Source: TERA Environmental Consultants Ltd. 1993. Environmental impact assessment for the Conwest Exploration Company Limited Sexsmith Gas Plant. TERA Environmental Consultants Ltd.

2. Alberta Status, Source: Wallis, C., C. Bradley, M. Fairbarns and V. Loewen. 1987. The rare flora of Alberta: Volume 3, species summary sheets. Alberta Forestry, Lands and Wildlife. 


\begin{tabular}{|c|c|c|}
\hline & SPECIES & $\begin{array}{l}\text { Provincial / National } \\
\text { Conservation Status* }\end{array}$ \\
\hline \multicolumn{3}{|l|}{ HERPTILES } \\
\hline tiger salamander & Ambystoma tigrinum & - \\
\hline western toad & Bufo boreas & -- \\
\hline wood frog & Rana sylvatica & - \\
\hline \multicolumn{3}{|l|}{ MAMMALS } \\
\hline masked shrew & Sorex cinereus & -- \\
\hline dusky shrew & Sorex monticolus & - \\
\hline water shrew & Sorex palustris & - \\
\hline arctic shrew & Sorex arcticus & - \\
\hline pygmy shrew & Sorex hoyi & - \\
\hline little brown bat & Myotis lucifugus & - \\
\hline northern long-eared bat & Myotis septentrionalis & Blue-listed in Alberta \\
\hline long-legged bat & Myotis volans & - \\
\hline silver-haired bat & Lasionycteris noctivagans & -- \\
\hline big brown bat & Eptesicus fuscus & - \\
\hline hoary bat & Lasiurus cinereus & - \\
\hline snowshoe hare & Lepus americanus & - \\
\hline least chipmunk & Tamias minimus & - \\
\hline woodchuck & Marmota monax & - \\
\hline columbian ground squirrel & Spermophillus columbianus & - \\
\hline red squirrel & Tamiasciurus hudsonicus & - \\
\hline northern flying squirrel & Glaucomys sabrinus & Yellow B-listed in Alberta \\
\hline beaver & Castor candensis & - \\
\hline deer mouse & Peromyscus maniculatus & - \\
\hline bushy-tailed woodrat & Neotoma cinerea & - \\
\hline southern red-backed vole & Clethrionomys gapperri & -- \\
\hline
\end{tabular}




\begin{tabular}{|c|c|c|}
\hline heather vole & Phenacomys intermedius & -- \\
\hline meadow vole & Microtus pennsylvanicus & -- \\
\hline muskrat & Ondatra zibethica & - \\
\hline northern bog lemming & Synaptomys borealis & -- \\
\hline meadow jumping mouse & Zapus hudsonius & -- \\
\hline western jumping mouse & Zapus princeps & -- \\
\hline porcupine & Erethizon dorsatum & - \\
\hline coyote & Canis latrans & -- \\
\hline gray wolf & Canis lupus & -- \\
\hline red fox & Vulpes vulpes & -- \\
\hline black bear & Ursus americanus & - \\
\hline grizzly bear & Ursus arctos & Blue-listed in Alberta \\
\hline pine marten & Martes americana & - \\
\hline fisher & Martes pennanti & Yellow B-listed in Alberta \\
\hline ermine & Mustela erminea & -- \\
\hline least weasel & Mustela nivalis & - \\
\hline long-tailed weasel & Mustela frenata & Yellow A-listed in Alberta \\
\hline mink & Mustela vison & - \\
\hline wolverine & Gulo gulo & $\begin{array}{c}\text { Designated by COSEWIC as } \\
\text { vulnerable in Canada } \\
\text { Blue-listed in Alberta }\end{array}$ \\
\hline striped skunk & Mephitis mephitis & -- \\
\hline river otter & Lutra canadensis & - \\
\hline Canada lynx & Lynx canadensis & Yellow B-listed in Alberta \\
\hline elk & Cervus canadensis & -- \\
\hline mule deer & Odocoileus hemionus & - \\
\hline white-tailed deer & Odocoileus virginianus & -- \\
\hline moose & Alces alces & -- \\
\hline
\end{tabular}




\begin{tabular}{|c|c|c|}
\hline \multicolumn{3}{|l|}{ BIRDS } \\
\hline common loon & Gavia immer & - \\
\hline horned grebe & Podiceps auritus & Yellow A-listed in Alberta \\
\hline eared grebe & Podiceps nigricollis & - \\
\hline trumpeter swan & Cygnus buccinator & Blue-listed in Alberta \\
\hline Canada goose & Branta canadensis & -- \\
\hline green-winged teal & Anas crecca & - \\
\hline mallard & Anas platyrhynchos & - \\
\hline northern pintail & Anas acuta & - \\
\hline blue-winged teal & Anas discors & - \\
\hline gadwall & Anas strepera & - \\
\hline common goldeneye & Bucephala clangula & - \\
\hline bald eagle & Haliaeetus leucocephalus & Yellow B-listed in Alberta \\
\hline northern harrier & Circus cyaneus & Yellow A-listed in Alberta \\
\hline red-tailed hawk & Buteo jamaicensis & - \\
\hline American kestrel & Falco sparverius & - \\
\hline merlin & Falco columbarius & - \\
\hline ruffed grouse & Bonasa umbellus & - \\
\hline sharp-tailed grouse & Tympanuchus phasianellus & Yellow A-listed in Alberta \\
\hline American coot & Fulica americana & - \\
\hline killdeer & Charadrius vociferus & - \\
\hline spotted sandpiper & Actitis macularia & - \\
\hline rock dove & Columba livia & - \\
\hline great-horned owl & Bubo virginianus & - \\
\hline great gray owl & Strix nebulosa & Yellow B-listed in Alberta \\
\hline yellow-bellied sapsucker & Sphyrapicus varius & - \\
\hline downy woodpecker & Picoides pubescens & - \\
\hline hairy woodpecker & Picoides villosus & -- \\
\hline three-toed woodpecker & Picoides tridactylus & -- \\
\hline
\end{tabular}




\begin{tabular}{|c|c|c|}
\hline northern flicker & Colaptes auratus & - \\
\hline pileated woodpecker & Dryocopus pileatus & Yellow B-listed in Alberta \\
\hline western wood pewee & Contopus sordidulus & -- \\
\hline alder flycatcher & Empidonax alnorum & - \\
\hline least flycatcher & Empidonax minimus & - \\
\hline eastern kingbird & Tyrannus tyrannus & - \\
\hline tree swallow & Tachycineta bicolor & -- \\
\hline bank swallow & Riparia riparia & - \\
\hline cliff swallow & Hirundo pyrrhonota & -- \\
\hline barn swallow & Hirundo rustica & - \\
\hline gray jay & Perisoreus canadensis & - \\
\hline blue jay & Cyanocitta cristata & - \\
\hline black-billed magpie & Pica pica & - \\
\hline American crow & Corvus brachyrhynchos & -- \\
\hline black-capped chickadee & Parus atricapillus & - \\
\hline boreal chickadee & Parus hudsonicus & - \\
\hline red-breasted nuthatch & Sitta canadensis & - \\
\hline house wren & Troglodytes aedon & - \\
\hline ruby-crowned kinglet & Regulus calendula & - \\
\hline Swainson's thrush & Catharus ustulatus & - \\
\hline hermit thrush & Catharus guttatus & - \\
\hline American robin & Turdus migratorius & - \\
\hline bohemian waxwing & Bombycilla garrulus & - \\
\hline cedar waxwing & Bombycilla cedrorum & - \\
\hline Eurpean starling & Sturnus vulgaris & - \\
\hline warbling vireo & Vireo gilvus & -- \\
\hline yellow warbler & Dendroica petechia & - \\
\hline yellow-rumped warbler & Dendroica coronata & - \\
\hline American redstart & Setophaga ruticilla & - \\
\hline
\end{tabular}




\begin{tabular}{|c|c|c|}
\hline common yellowthroat & Geothlypis trichas & - \\
\hline western tanager & Piranga ludovicianus & Yellow B-listed in Alberta \\
\hline rose-breasted grosbeak & Pheuticus ludovicianus & - \\
\hline chipping sparrow & Spizella passerina & - \\
\hline clay-coloured sparrow & Spizella pallida & Yellow A-listed in Alberta \\
\hline vesper sparrow & Pooecetes gramineus & -- \\
\hline song sparrow & Melospiza melodia & - \\
\hline white-throated sparrow & Zonotrichia albicolis & - \\
\hline dark-eyed junco & Junco hyemalis & - \\
\hline red-winged blackbird & Agelaius phoeniceus & - \\
\hline Brewer's blackbird & Euphagus cyanocephalus & - \\
\hline common grackle & Quiscalus quiscula & - \\
\hline brown-headed cowbird & Molothrus ater & - \\
\hline northern oriole & Icterus galbula & - \\
\hline purple finch & Carpodacus purpureus & - \\
\hline \multicolumn{3}{|l|}{ FISH } \\
\hline arctic grayling & Thymallus arcticus & - \\
\hline bull trout & Salvelinus namaycush & - \\
\hline northern pike & Esox lucius & - \\
\hline goldeye & Hiodon alosoides & - \\
\hline longnose dace & Rhinichthys cotaractae & - \\
\hline flathead chub & Platygobio gracilis & - \\
\hline lake chub & Couesius plumbeus & - \\
\hline redside shiner & Richardsonius balteatus & -- \\
\hline spottail shiner & Notropis hudsonius & -- \\
\hline longnose sucker & Catostomus catostomus & - \\
\hline white sucker & Catostomus commersoni & -- \\
\hline largescale sucker & Catostomus macrocheilus & - \\
\hline trout-perch & Percopsis omicomaycus & - \\
\hline
\end{tabular}




\begin{tabular}{|lll|}
\hline brook stickleback & Culaea inconstans & -- \\
\hline slimy sculpin & Cottus cognatus & - \\
\hline
\end{tabular}

* Species ranking definitions and criteria included in Section 3.0 


\section{APPENDIX 9.}

\section{PHOTOGRAPHS OF REPRESENTATIVE FEATURES OF THE SADDLE HILLS STUDY AREA.}




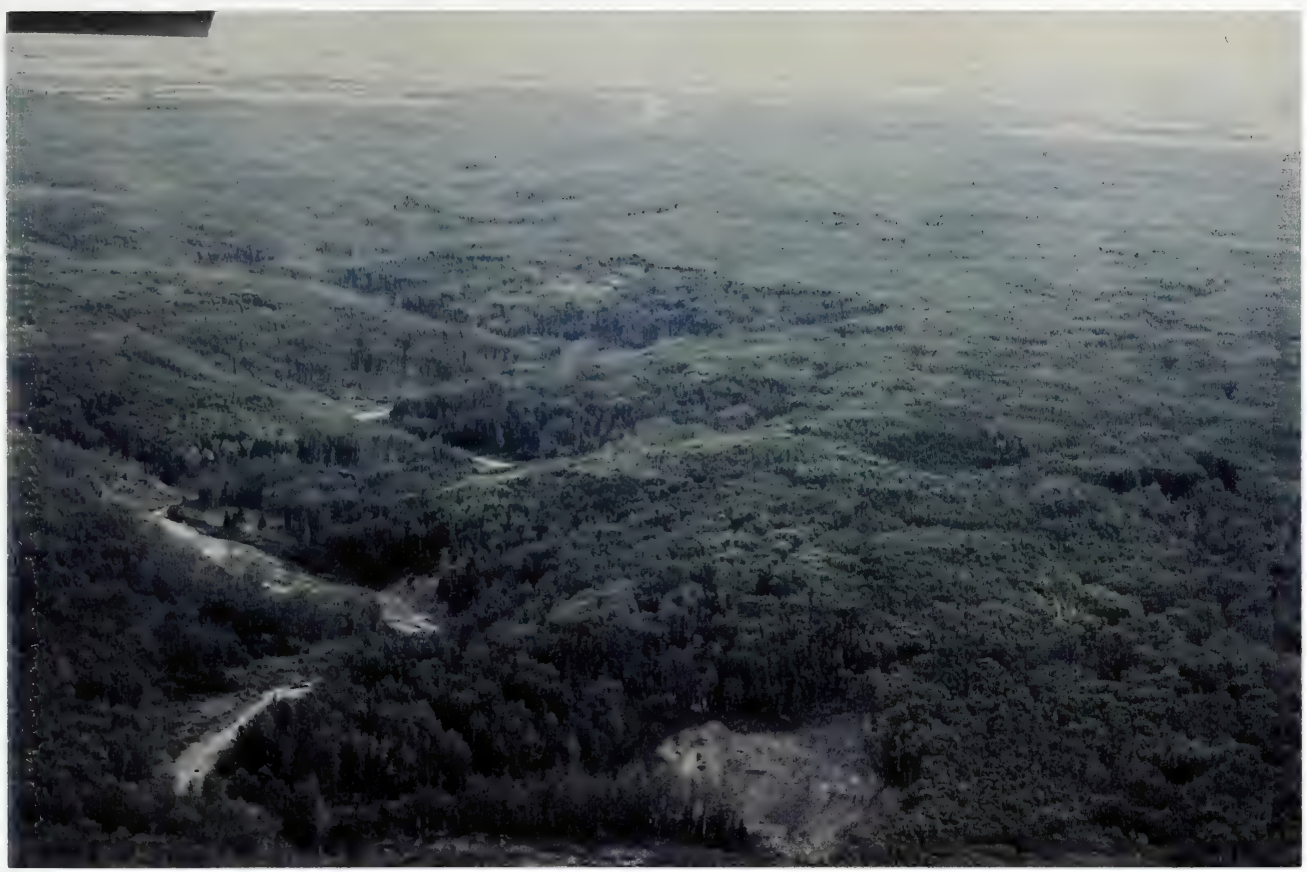

Plate 1: The Bad Heart River, originating within the Saddle Hills, is the major water course found within the study area. The valley provides important elk production and winter range while also serving as a movement corridor for many other wildlife species.

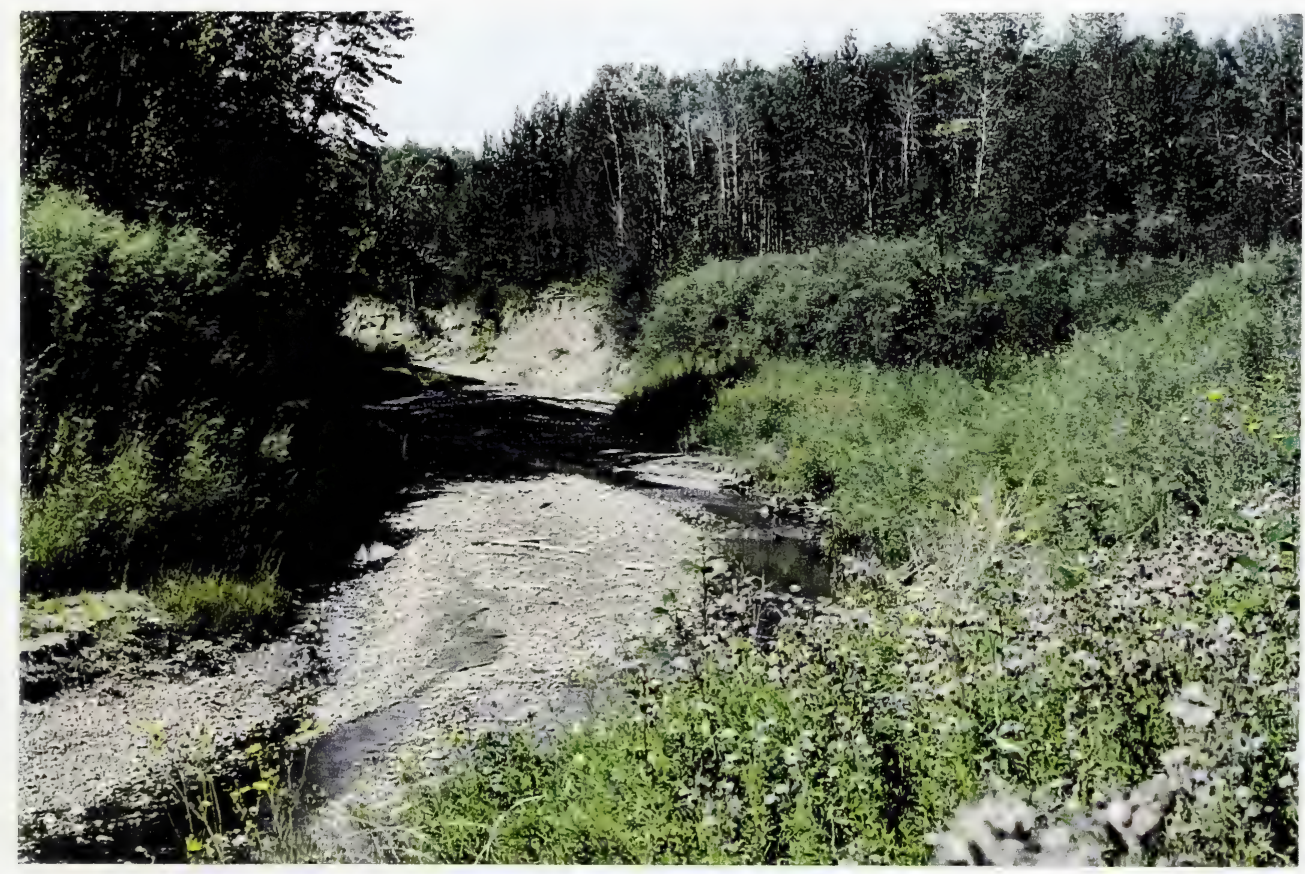

Plate 2: Vegetation species diversity along the floodplain and adjacent slopes of the Bad Heart River is high with aspen forest, grassland and upland shrubland communities all dominating. The river also acts as a corridor for weed invasion. Note the abundance of weeds species (i.e. Canada thistle) in the foreground of the above photo. 



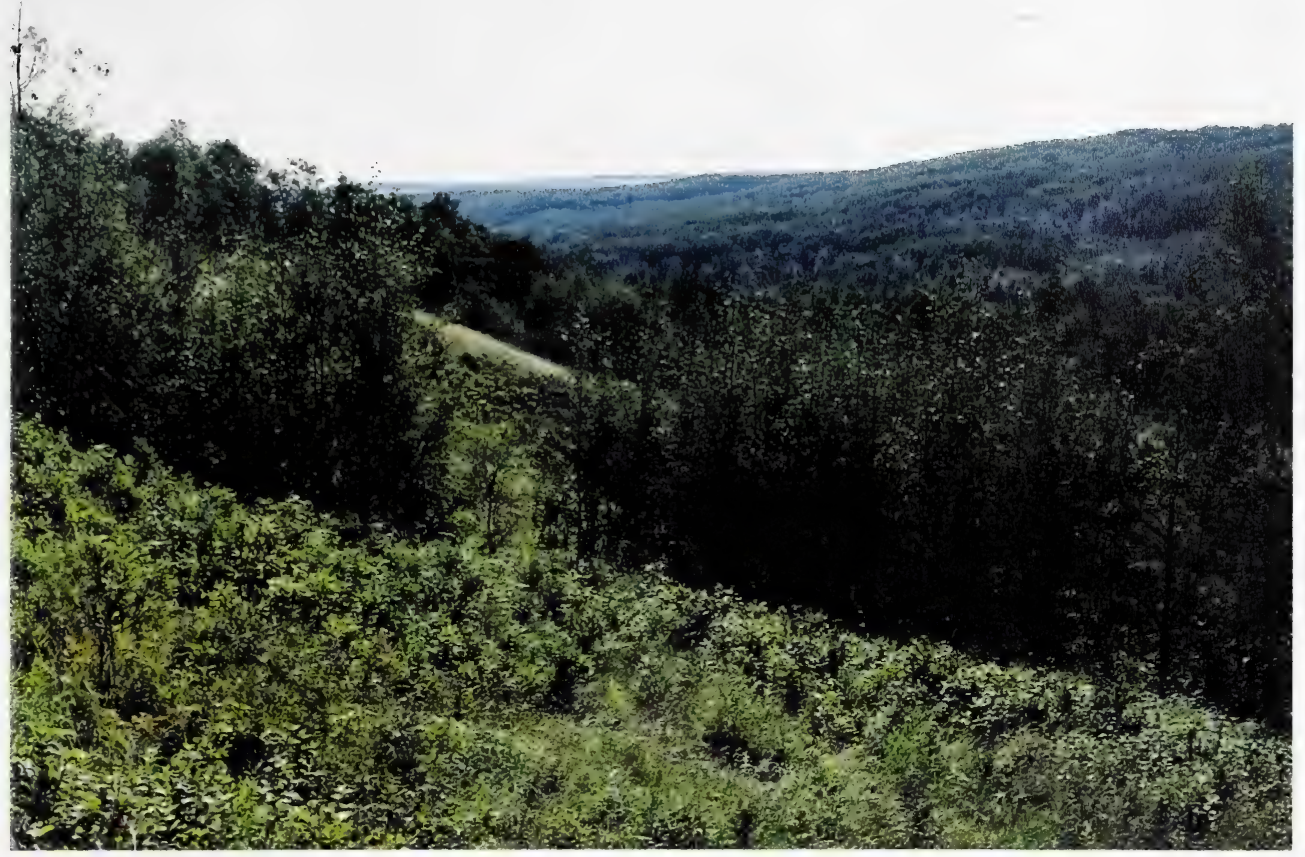

Plate 3: Aspen/prickly rose-common snowberry/awnless brome-bluejoint community type occurring on fluvial and glaciofluvial materials in the Bad Heart River Valley. The prickly rose-common snowberry/awnless brome-bluejoint phase dominates drier sites while aspen cover increases as moisture availability increases.

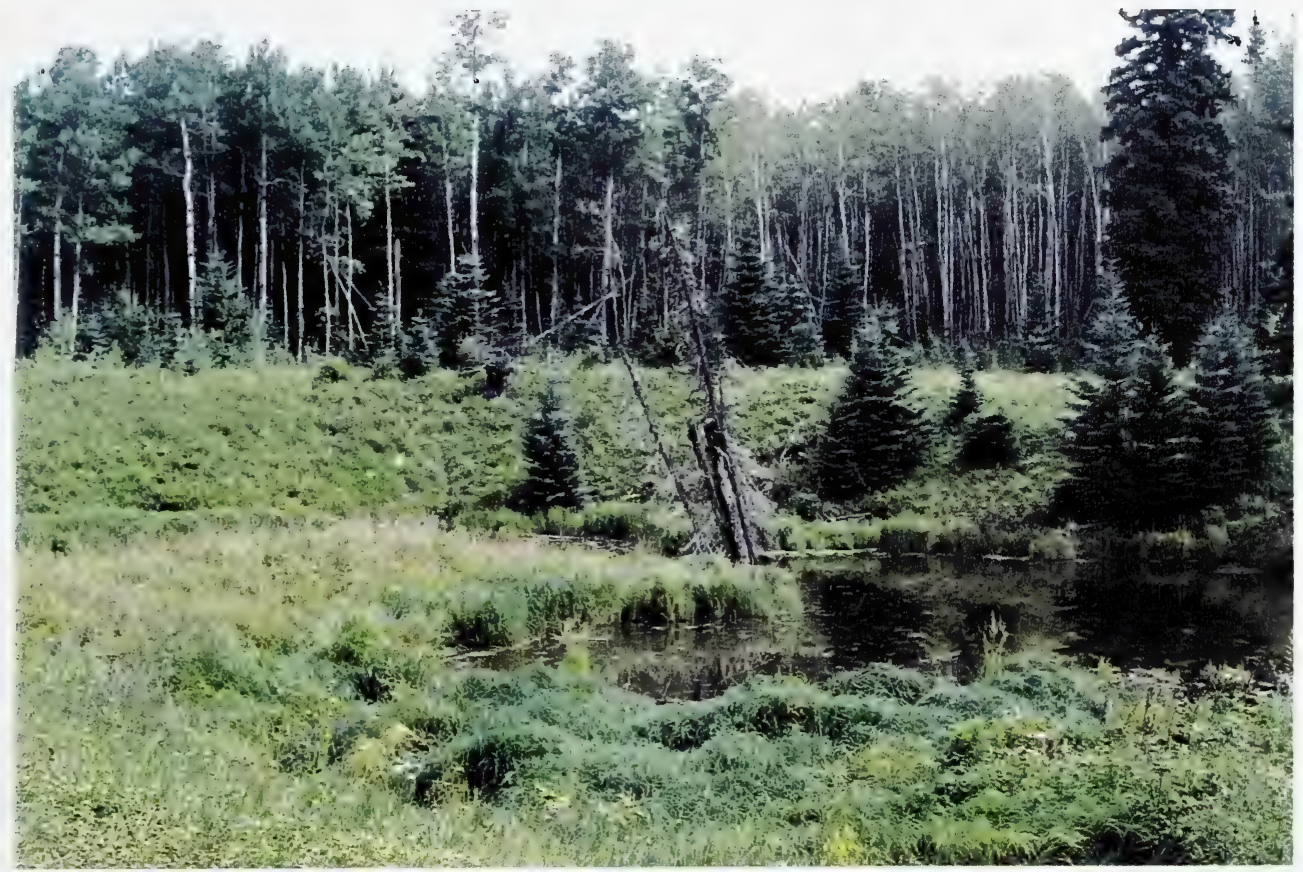

Plate 4: Prickly rose-common snowberry/awnless brome-bluejoint community type occurring on fluvial materials. Regenerating tree species, such as the white spruce in the background, are unable to form a canopy due to periodic flooding. This enables gramminoid communities to dominate areas immediately adjacent to major watercourses. 



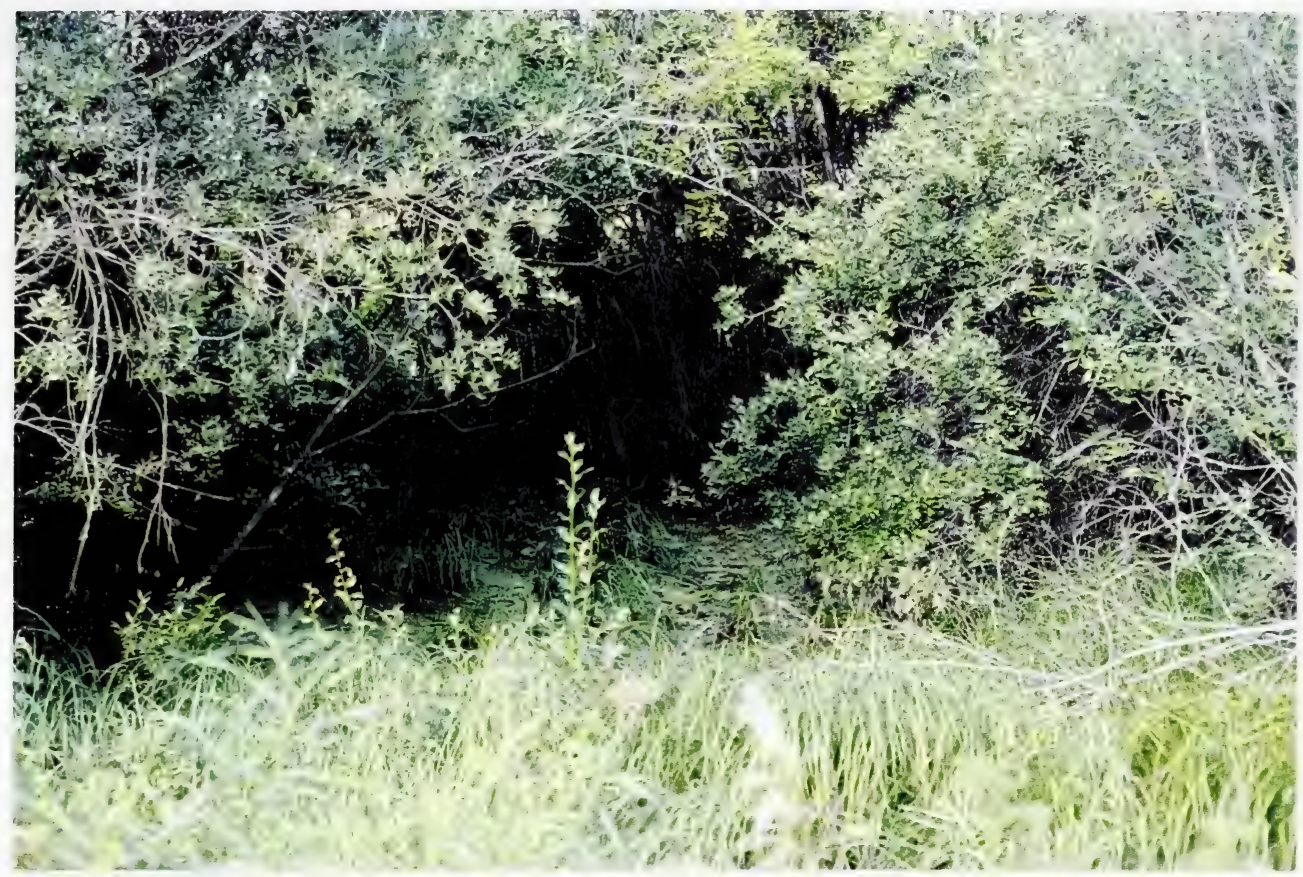

Plate 5: Upland shrub and aspen dominated communities, such as the Aspen-balsam poplar/red-osier dogwood-prickly rose community type, dominate wetter areas adjacent to smaller creeks not suspectable to periodic flooding.

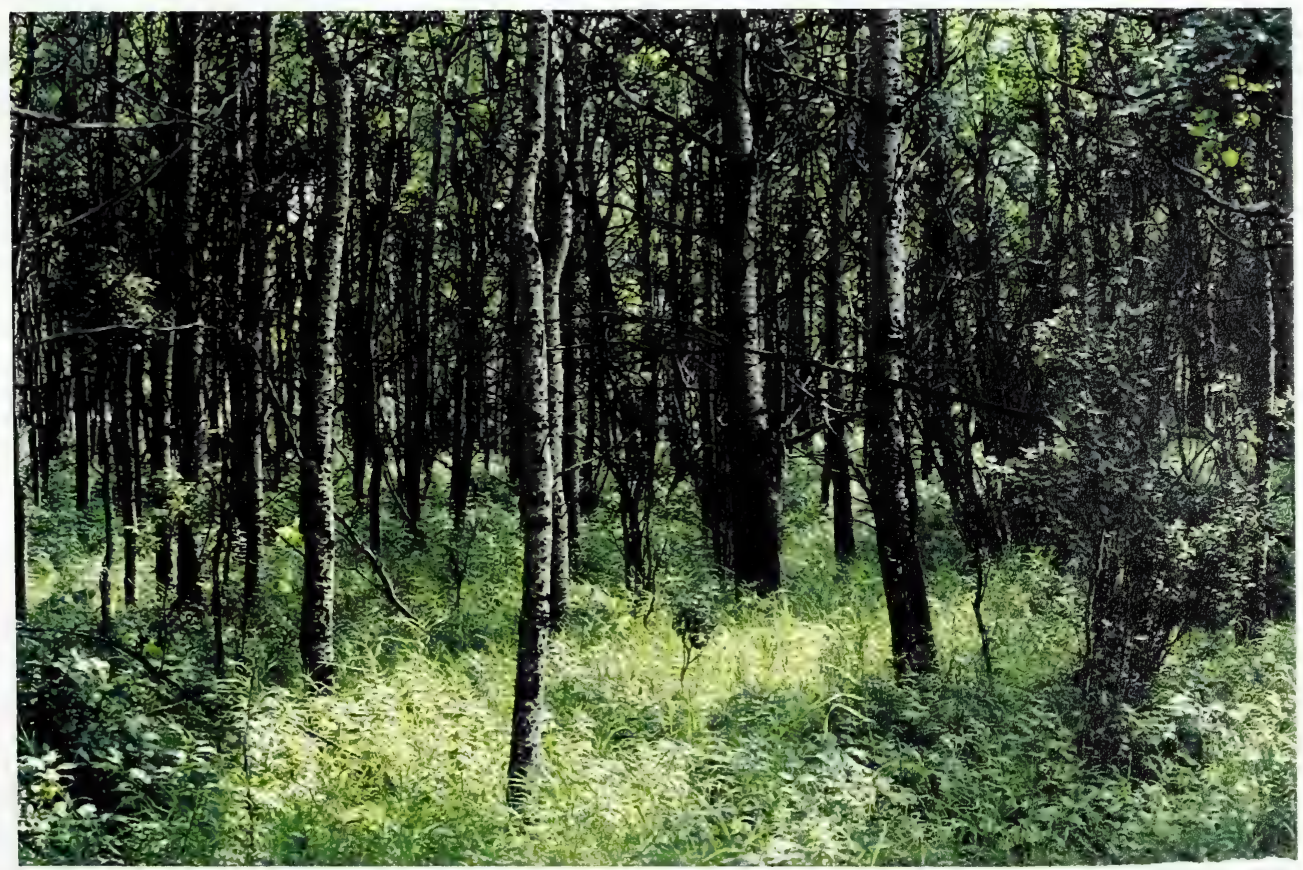

Plate 6: The most abundant community occurring within the study area is the Aspen/prickly rose-low bush cranberry/bluejoint community shown above. This community generally occurs on moderately well drained, undulating, fine-textured morainal deposits. 



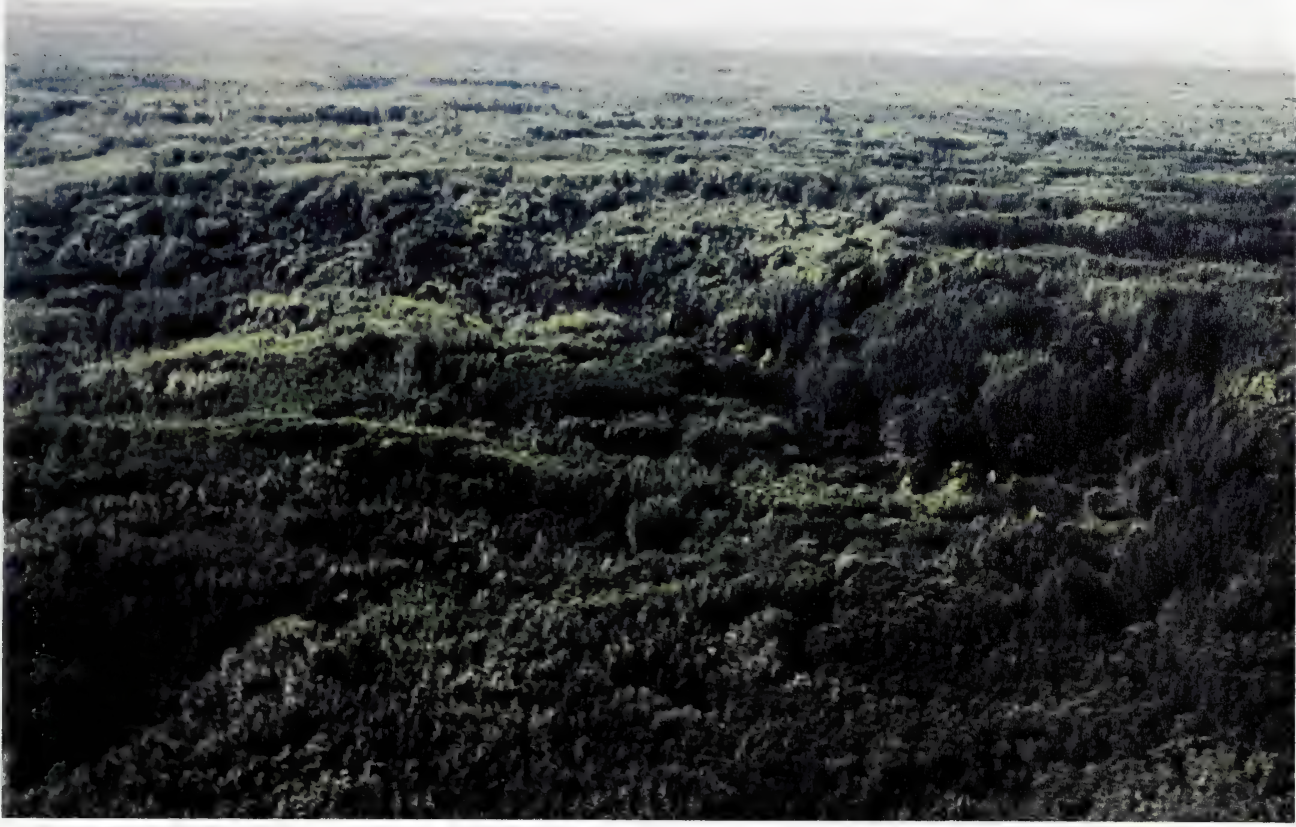

Plate 7: The northern escarpment represents the most significant elevational change within the study area. It is formed by the southern incline of the local bedrock and marks the northern extremity of the Saddle Hills. This escarpment is used as a movement corridor by numerous wildlife species, particularly elk, moose, and black bear.

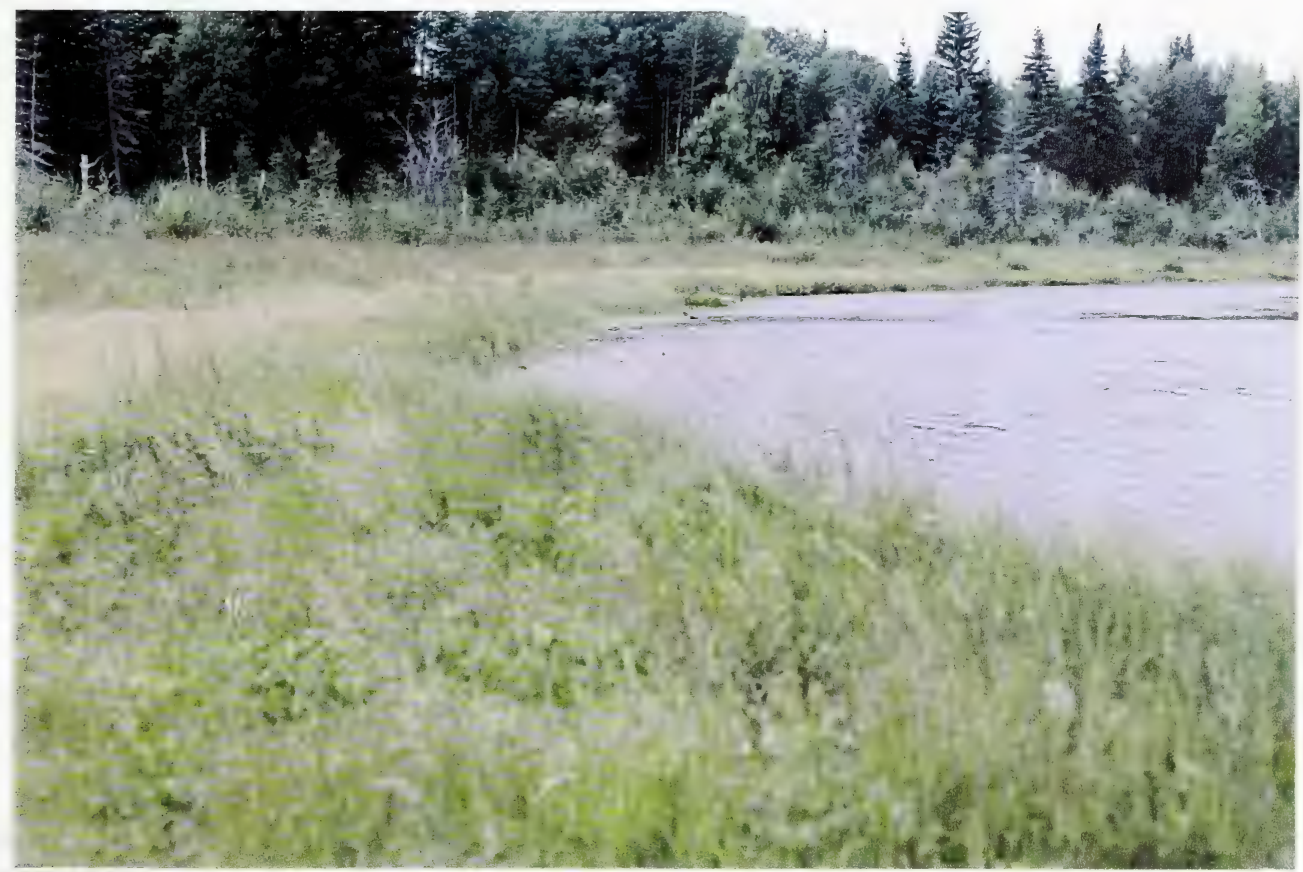

Plate 8: Bluejoint/buckbean/beaked sedge community type occurring on course-textured lacustrine materials of Hilltop Lake. This community is commonly found along the shorelines of wetlands and lakes. 



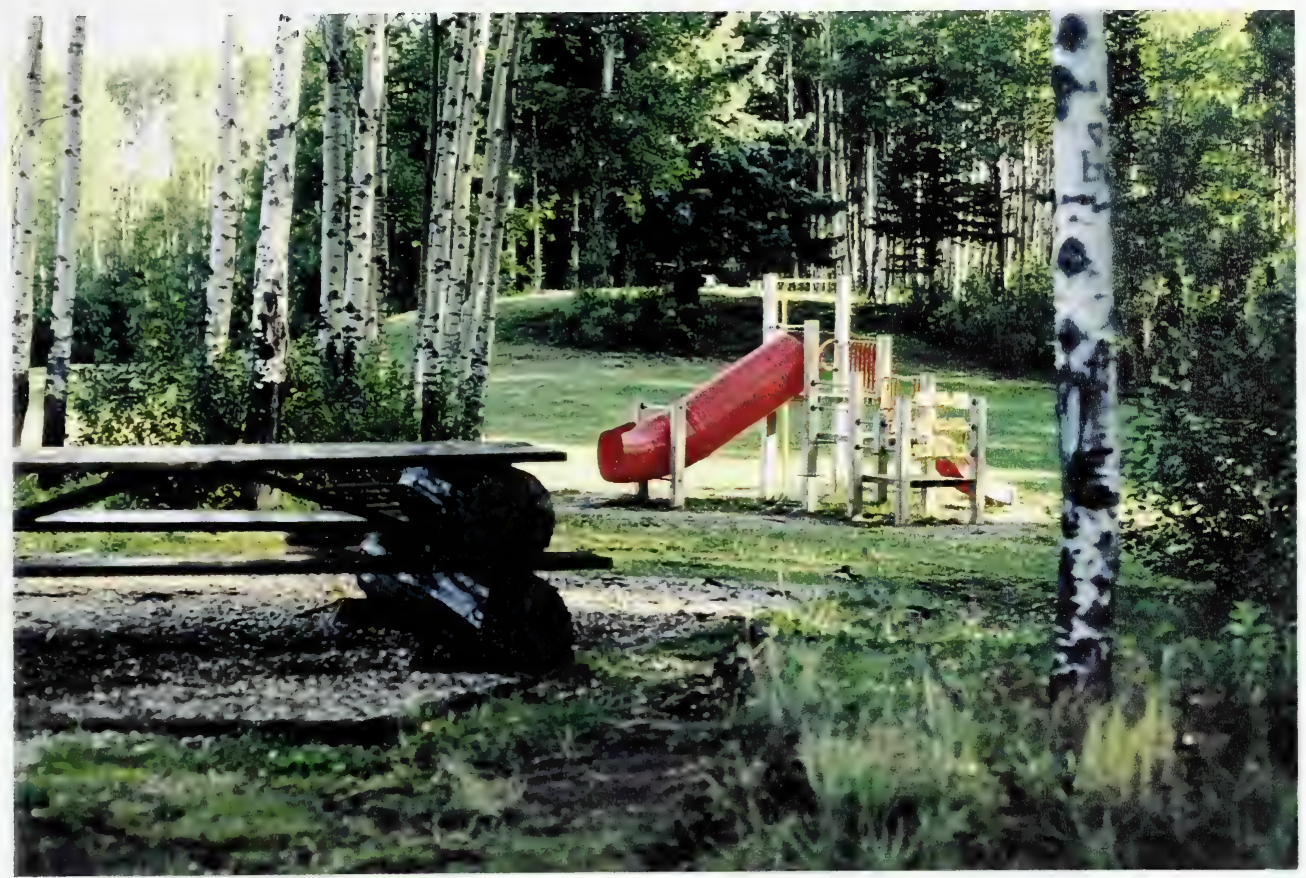

Plate 9: The Hilltop Lake recreational site is the only such site found within the study area.

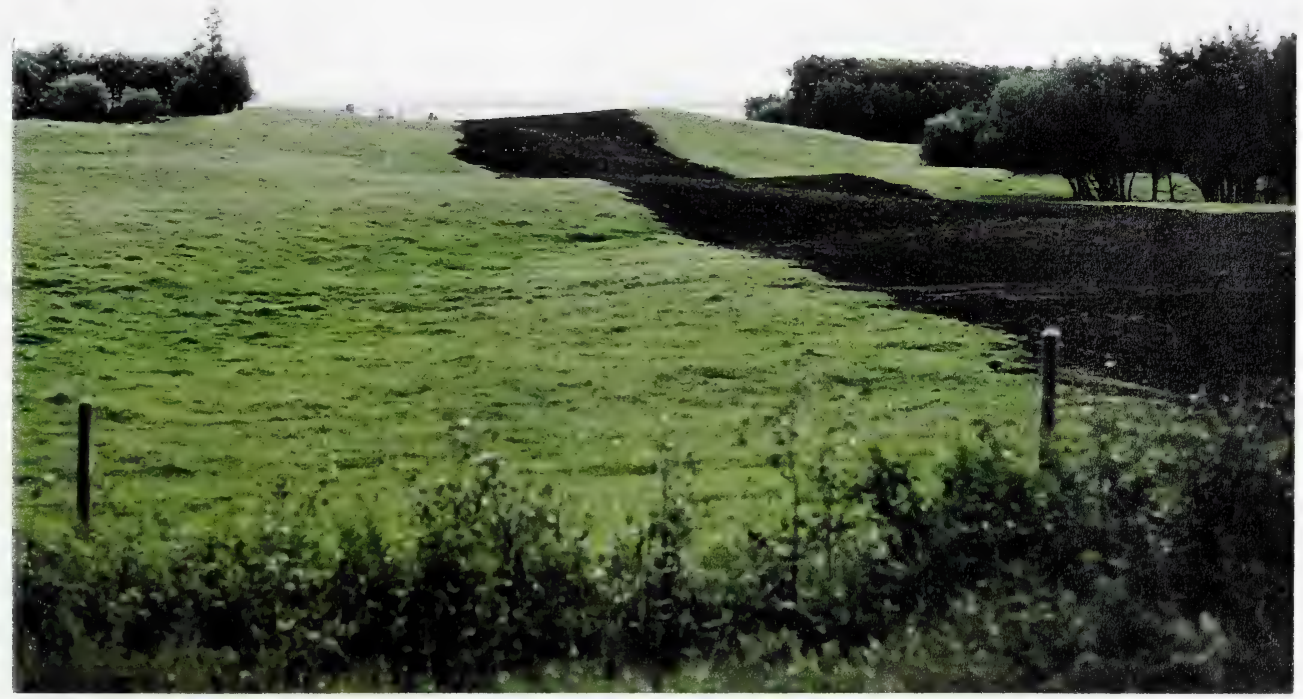

Plate 10. Gently undulating to hummocky topography is the dominant landform found within the study area. Disturbances, such as pipeline right-of-way and cultivation, are widespread on the fringes of the Saddle Hills. 



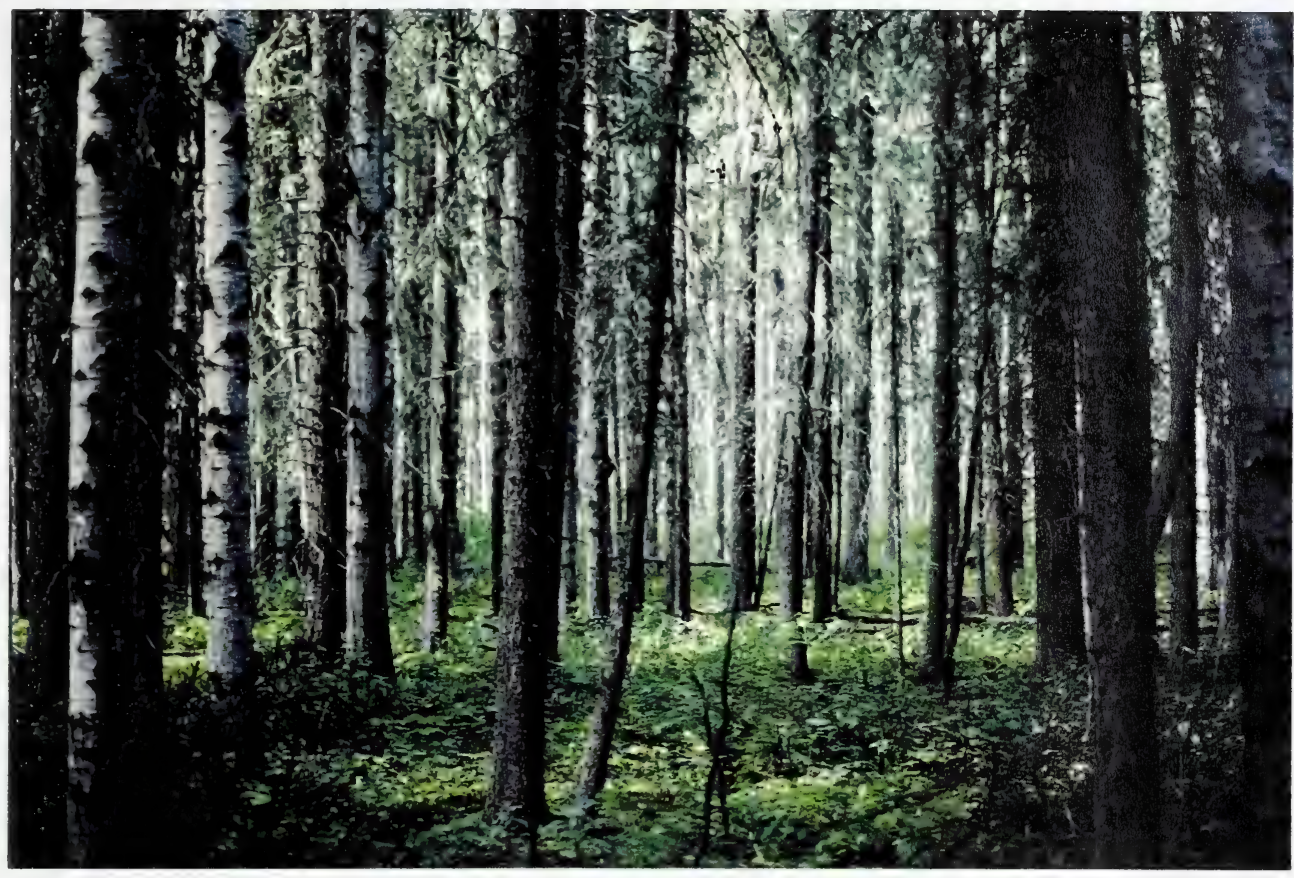

Plate 11. White spruce/bunchberry/feathermoss community type occurring on morainal materials (M1 ecosite). Coniferous stands such as these are uncommon in the the Saddle Hills.

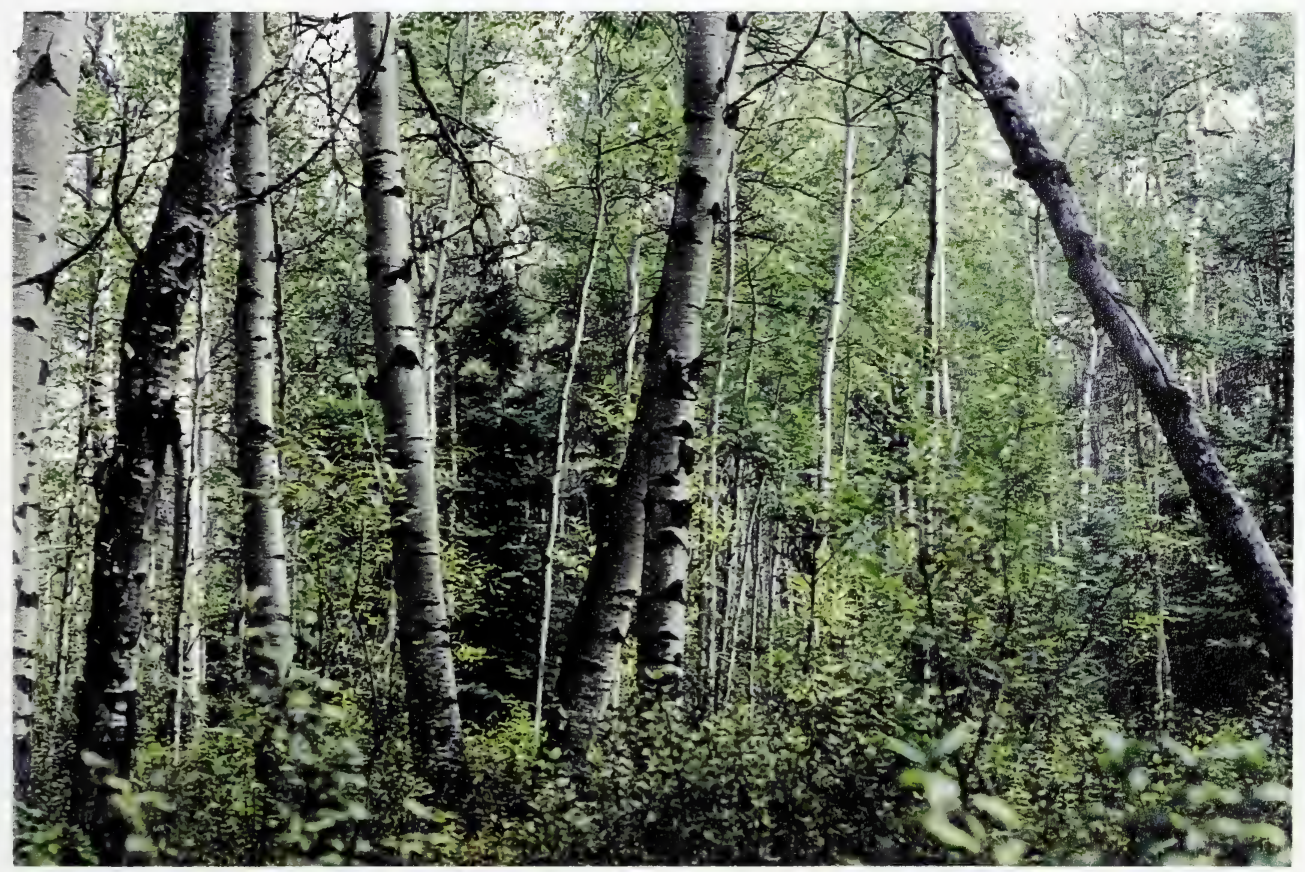

Plate 12. Aspen/Canadian buffaloberry/bunchberry community type occurring on morainal materials. This community is generally found on drier sites and southern aspects. 



\section{SADDLE HILLS SIGNIFICANT FEATURES AND AREAS OF DISTURBANCE}

SIGNIFICANT AREAS

WIIVIV Areos of Significance
1 - Bod Heart River and Tributaries

- Bod Heort River ond Tributarios
2- Kleskin Creek Tributaries

3 - Northern Escorpment

4 - Bear River Tributaries

5 - Soddle (Burnt) River Tributaries

6 - Hill top Lake
DISTURBANCE TYPE

Areas of Disturbance

C - Cultivoted (Improved) Lod

$F$ - Farmstead

$S$ - Subdivision

$G-$ Gos Plont

$R$ - Recreation site

D - Dugout
SCALE $1: 65,000$

BASE MAP FEATURES

LINEAR DISTURBANCE FEATURES

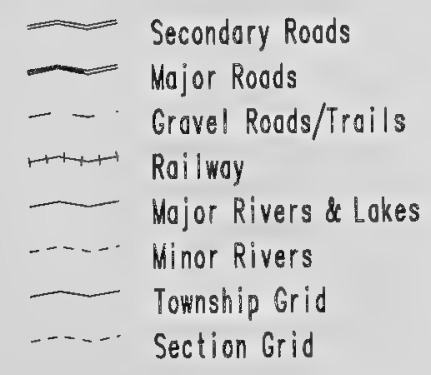

_ Secondary Roods

_. Mojor Roods

Roilwoy

HA Pipe Lines

Well sites 



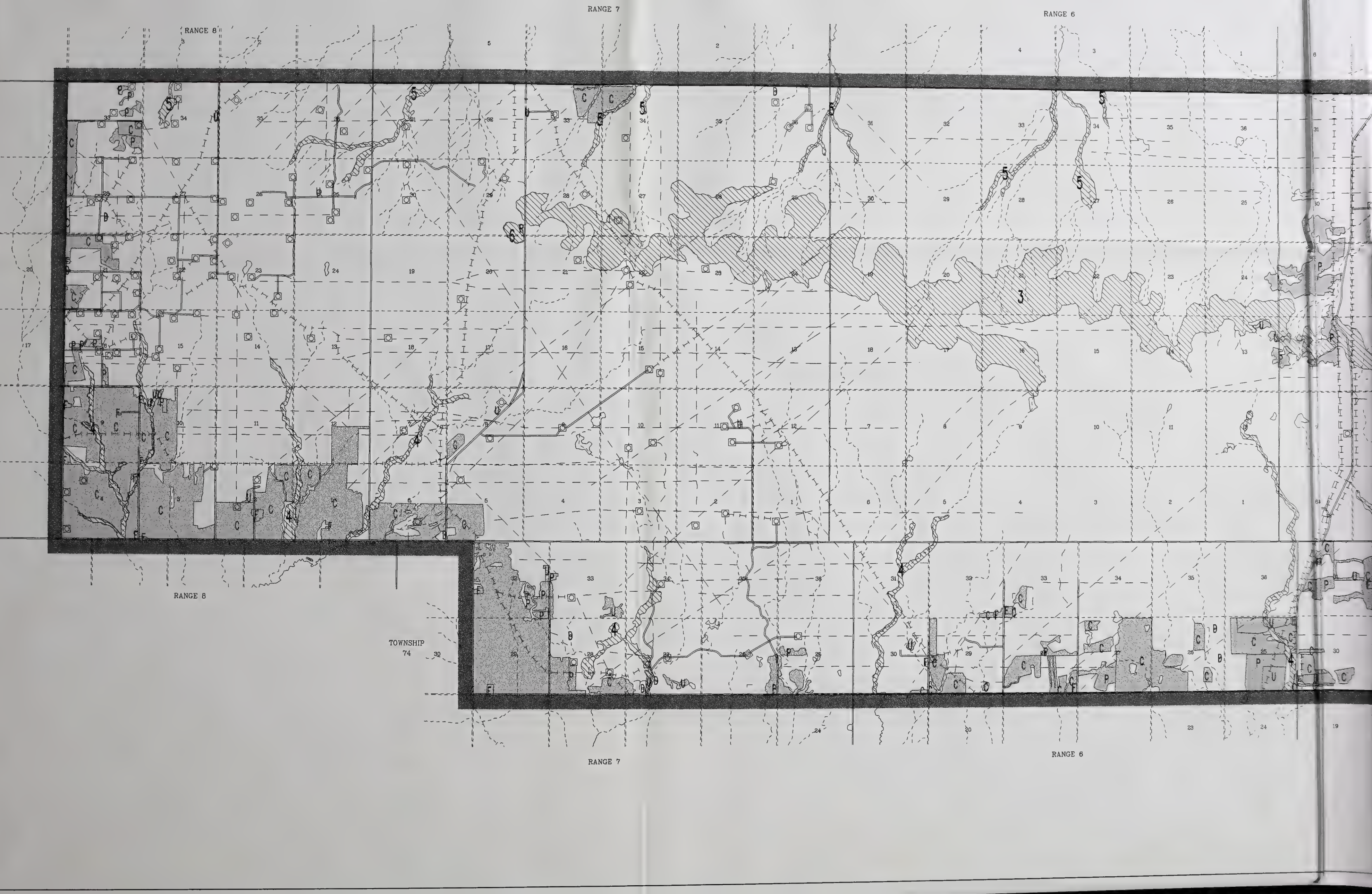




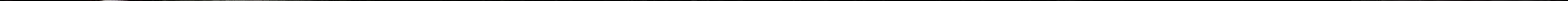




\section{SADDLE HILLS ECOLOGICAL LAND CLASSIFICATION SCALE 1:65,000}

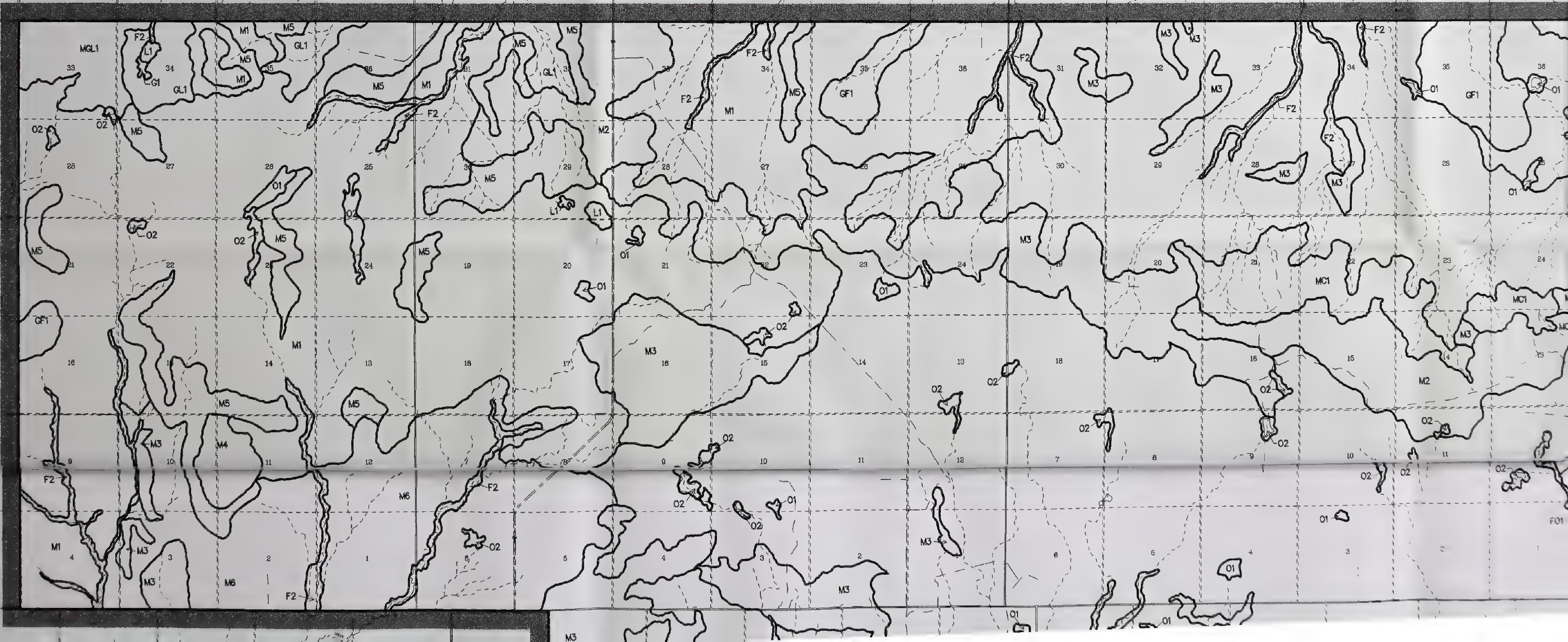




\section{LEGEND}

BASE MAP FEATURES

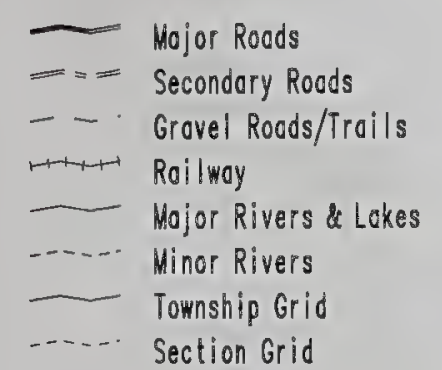

\section{ECOSITES}

— ECOSITE POLYONS

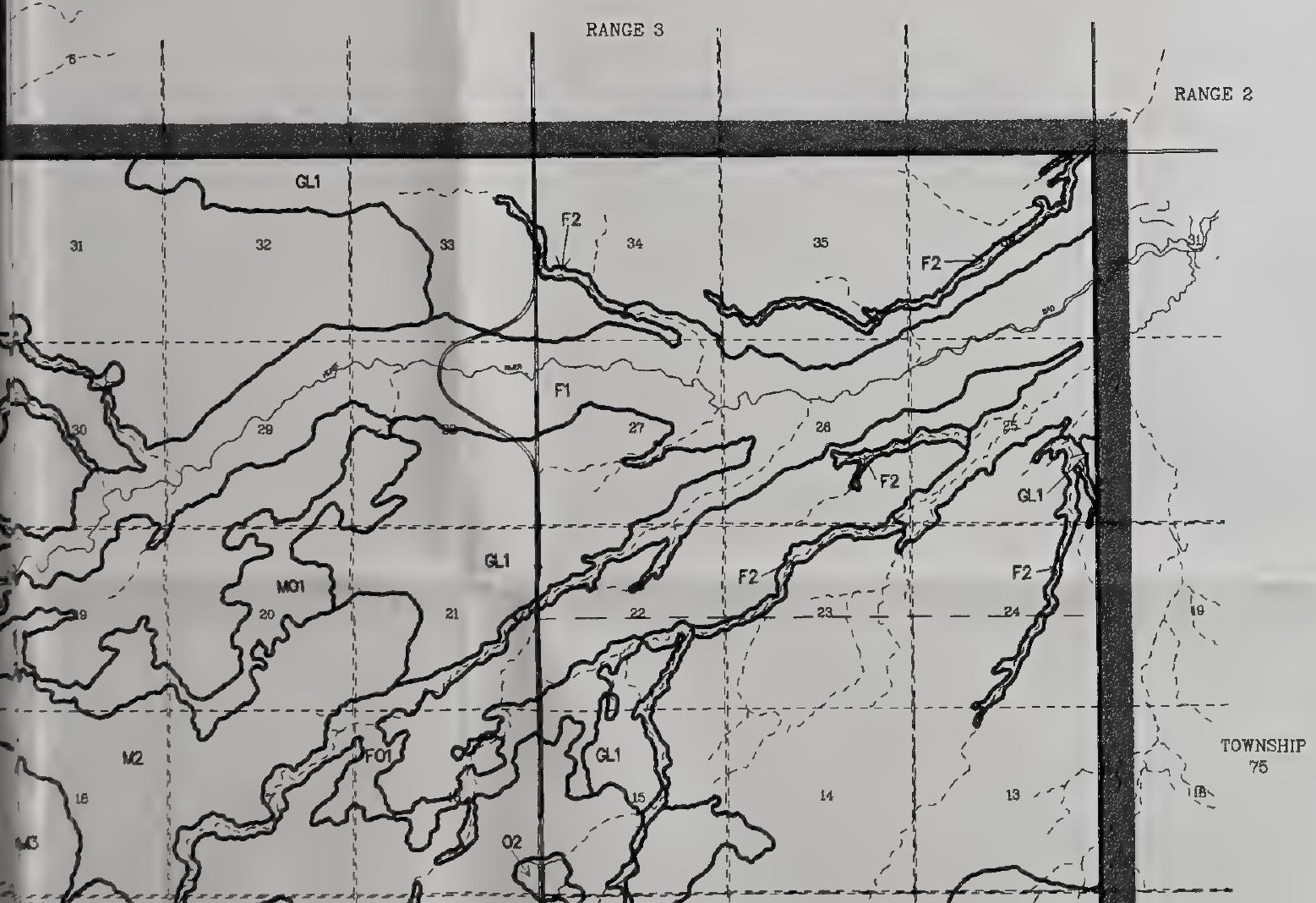

SCOSITE LANDEORM AND SURFICIAL MATERIAL

VEgetation

FIUVIAL

F1 Incised, Y-shoped voll ley of the Bod Heart River; low

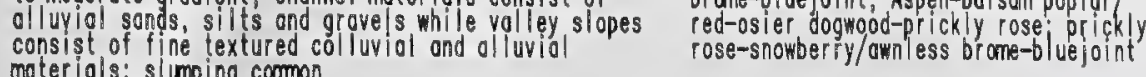

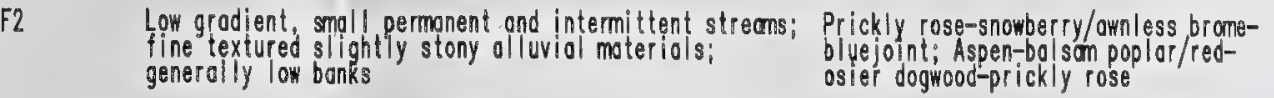
FLUVIAL AND ORGANIC

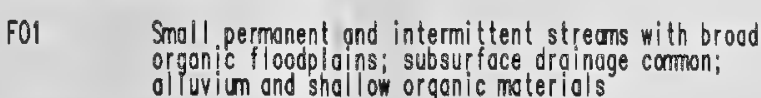
GLACIOFLUVIAL

Gently sloping mel twoter channels; discontinuous
glociof luvial veneers ond blonkets over moroine

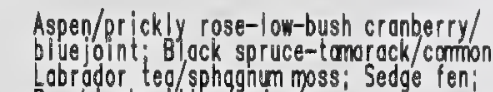

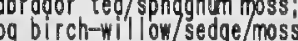

Aspen/prickly rose-low-bush cronberry/
wild sarsoparilio

\section{GLACIOLACUSTRINE}

QL1 Oiscontinuous undulating to inclined fine textured

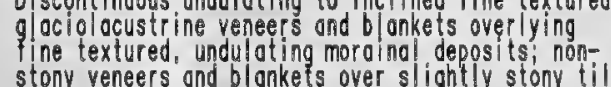
LACUSTRINE

L1 Level to gently undul oting lacustrine deposits with

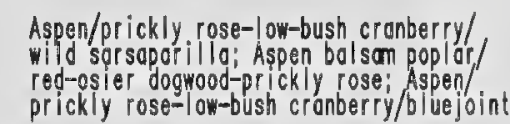

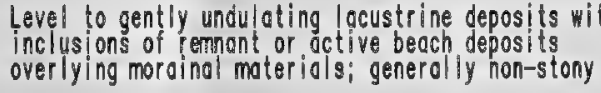

MORAINE AND GLACIOLACUSTRINE

Discont inuous medium, textured glaciolocustrine beach
deposits occurring with undul ot ing morainal bl ankets

Blue joint-beeked sedge/buck-been; Cot toil-sedge DORAINE

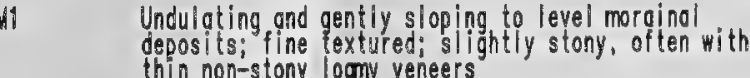

Undulating, and gently sloping to level morainal
deposits; fine textured ond very slony

Moderately to steeply inclined and roll ing morainol
deposits; fine textured ond very stony

44. Undulgting, roll ing and inclined mor ainal deposit medium to coorse textured; non
Aspen-bolsam poplar/green alder/bluejoint

Aspen/prickly rose-snowberry/awnless brome;
Aspen/grickly rose-low-bush crontery

bivejiont: Aspen/prickly rose-low-bus

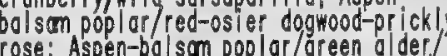

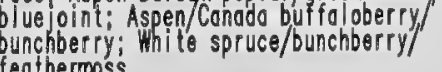

Aspen/pri ckly rose-snowberry/amnless brome/

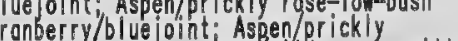

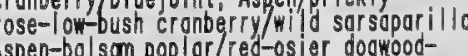

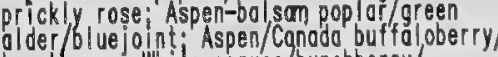
bunchberty; whit sprucelbunchberry/ dory

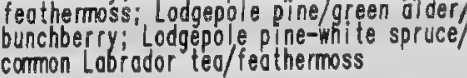

Aspen/prickly rose-low-bush cranberry/wild

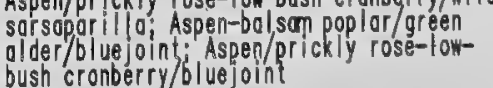

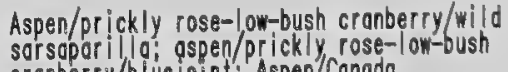
cronberry/blyejoint: Asperis
buffal ooerrybunchberry 




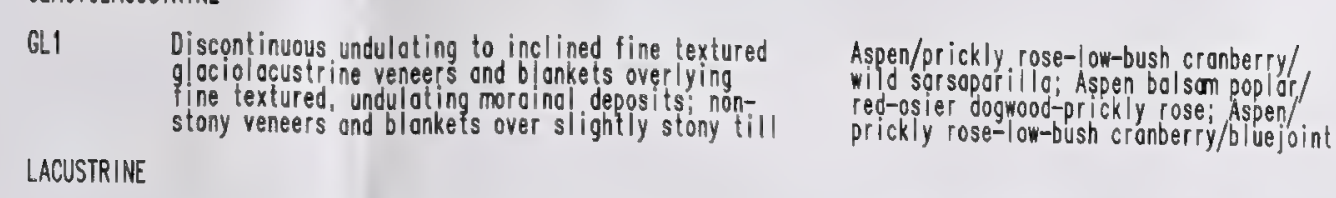

L1 Level to gently undulating gecustrine deposits with

Bluejoint-beaked sedge/buck-been; Cattai I-sedge

HOOAANE AND CLACIOLACSTRNIE

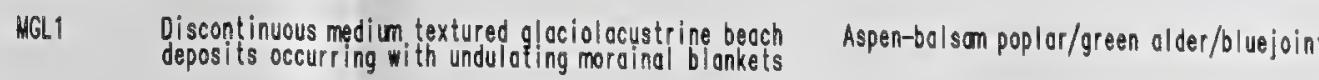

MORAINE

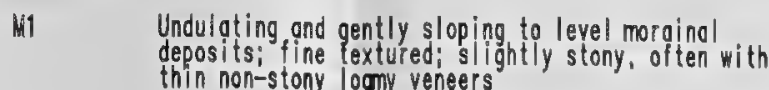

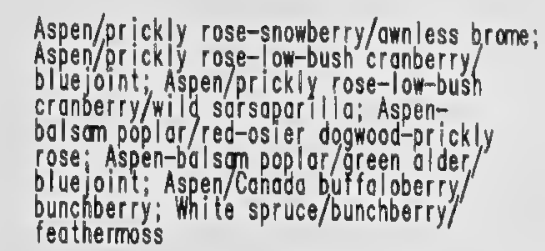

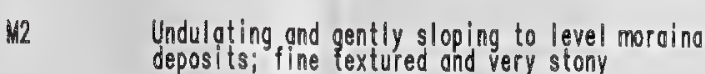

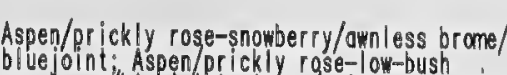

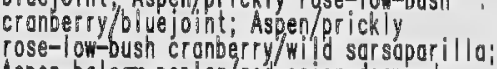

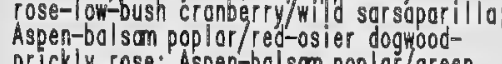

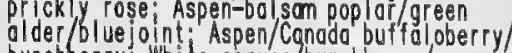

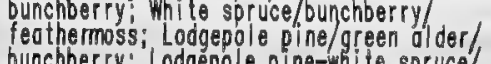

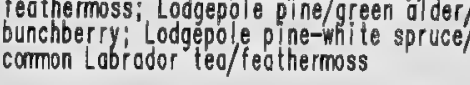

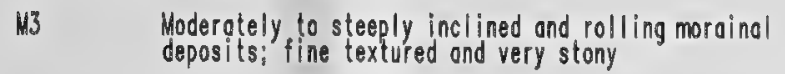

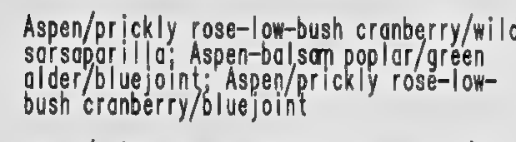

H4 Undulgting, roll ing and inclined mora inal deposits

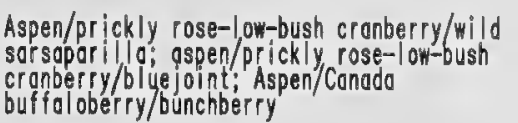

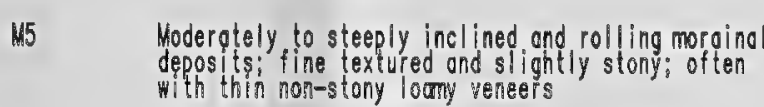

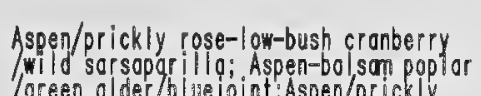

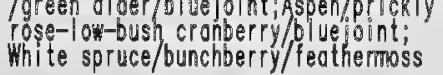

W6 Unduluting to hummocky morainal deposits; fineAspen/pricklyl rose-loutbush crabberty

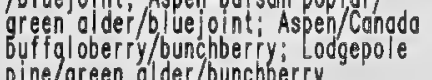

W7 Gentily sloping morainal deposits; fine textured

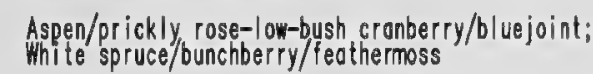

MORAINE AND COLLVVIUM

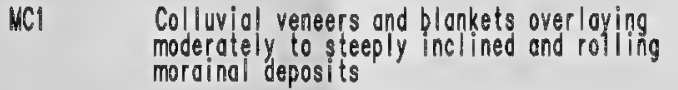

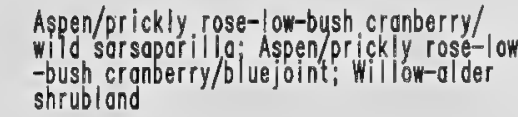

MORAINE ANO ORGANIC

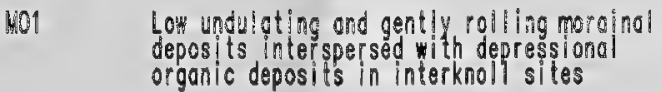

ORGANIC

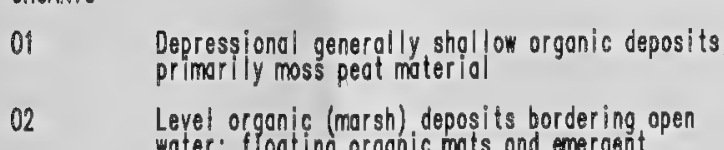

RANat

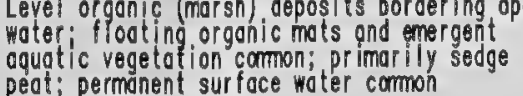

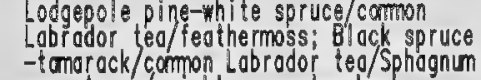

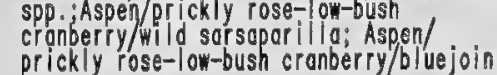

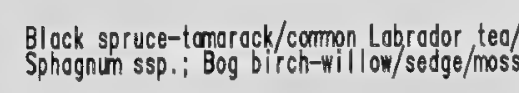
Seldge fen; Cattoi l-sodge 
SADDLE HILLS SENSITIVE AREAS

槽

SCALE 1:65,000

SENSITIVITY RATING

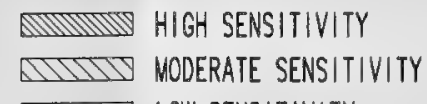

$\square$ LOW SENSITIVITY

\section{BASE MAP FEATURES}

- Nojor Rods

Secondory Roods

Grovel Roods/Trails

Roilwoy

Mojor Rivers \& Lokes

Minor Rivers

Tounship Grid 




